\title{
A NEW LATE BRONZE AGE WARRIOR EQUIPMENT FROM EAST CENTRAL EUROPE
}

\author{
JÁNOS GÁBOR TARBAY*
}

\begin{abstract}
The aim of this study is to evaluate a Late Bronze Age (Ha A-Ha B1) "assemblage" in the collection of the MoD Military History Institute and Museum (Budapest). It consists of significant defensive (greaves, conical helmet) and offensive weapons (a flange-hilted sword with a mount of the sheath) as well as a Fuchsstadt type cup, three flange-hilted knives, a wagon model part and several other unidentifiable sheet bronze fragments. According to the museum's inventory book, the objects in question were acquired in the 1990s. Unfortunately, their find-spot and find circumstances have not been recorded. Nevertheless, the results of the macroscopic examination and the typo-chronological analysis suggest that the artefacts probably buried together as parts of an East Central European (perhaps Hungarian) hoard or grave assemblage.
\end{abstract}

Keywords: Ha A1-Ha B1, defensive and offensive weapons, X-Ray analysis, destruction, "warrior set"

A tanulmány célja egy közöletlen - a HM Hadtörténeti Intézet és Múzeum gyüjteményében található - késó bronzkori (Ha A-Ha B1) "leletegyüttes" bemutatása. A "lelet" kiemelkedo" tárgyai közétartoznak a különböző típusúvédőfegyverek (lábszárvédő, kónikus sisak) és egy nyélnyújtványos kard a hüvely veretével. Mellettük említésre méltó még egy Fuchsstadt-típusú csésze, három kés, egy kocsialkatrész és számos egyéb, azonosithatatlan fémlemeztöredék. A múzeum leltárkönyve alapján a tárgyak vélhetöleg az 1990-es években jutottak a múzeum birtokába, elókerülési körülményük és lelóhelyük nem ismeretes. A lelet technológiai és tipológiai jellemzói alapján nem zárható ki, hogy a kérdéses tárgyak eredendően egy kelet-közép-európai - akár magyarországi - depó vagy sírlelet részeként kerültek elrejtésre.

Kulcsszavak: Ha A1-Ha B1, védö- és támadófegyverzet, röntgenelemzés, megsemmisités, harcosfelszerelés

* János Gábor Tarbay. Eötvös Loránd University, Institute of Archaeological Sciences, H-1088 Budapest, Múzeum körút 4/B; Hungarian National Museum, H-1088 Budapest, Múzeum körút 14-16.; tarbay.gabor@hnm.hu; tarbayjgabor@ gmail.com 


\section{Introduction}

The "assemblage" 1 in question was acquired by the MoD Military History Institute and Museum in the 1990s (Fig. 15-19). It remained unknown to research until 2013 when Balázs Polgár "re-discovered" the finds and directed our attention to it. $^{2}$ Except for the probable year of acquisition, no additional information was recorded, and there- fore the exact find spot and the circumstances of the assemblage's discovery are wholly unknown. However, the results of the macroscopic examination $^{3}$ and the typo-chronological analysis in the present study strongly suggest that the objects in question could have been part of one "assemblage". It is important to note that the current number and state of the artefacts are not representative because almost every one bears clear

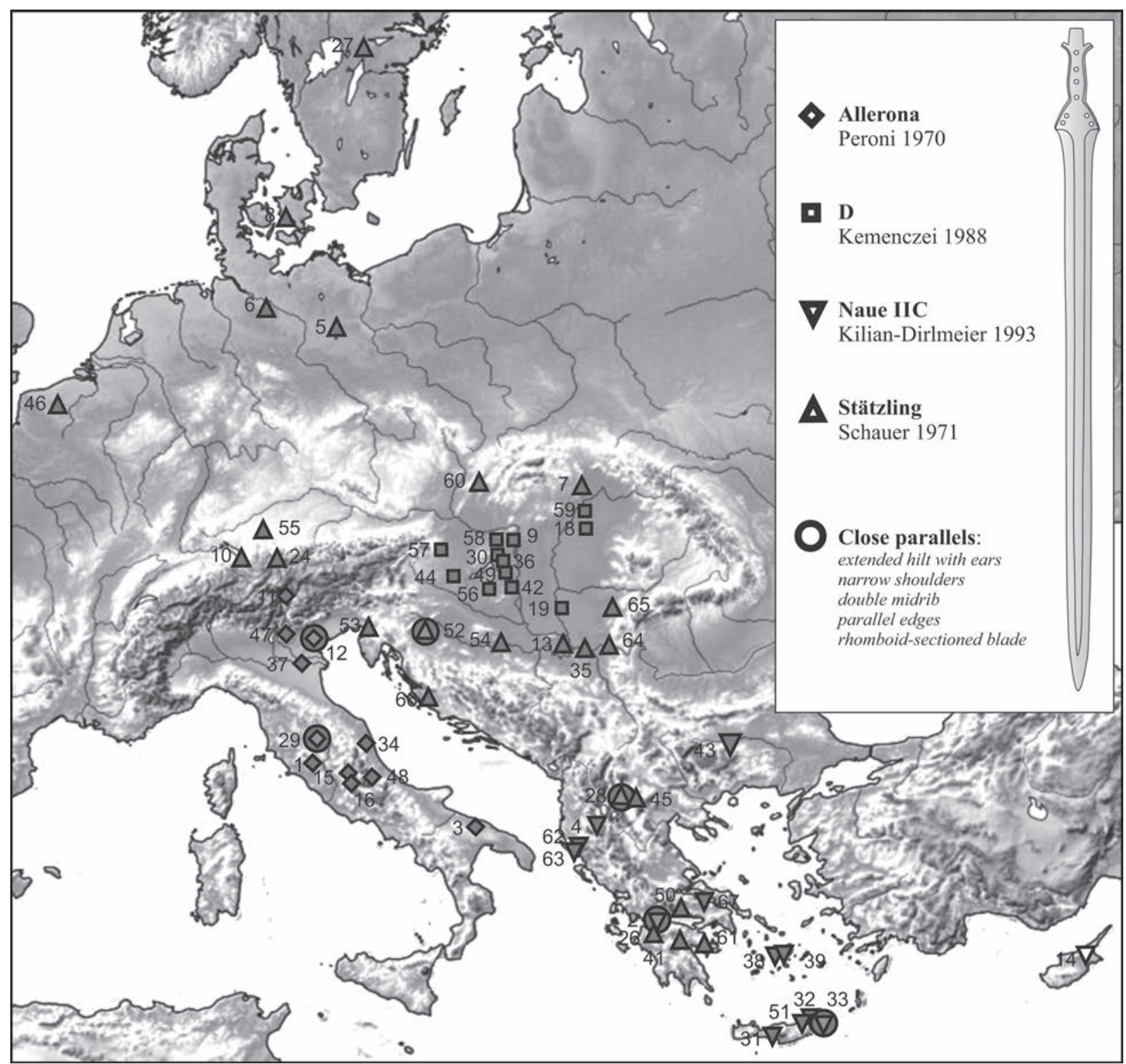

Fig. 1. Distribution of flange-hilted swords with extended tang (Allerona type, D type, Naue IIC type, Stätzling type)

1. kép. A hosszított markolatú, nyélnyújtványos kardok elterjedése (Allerona-típus, D-típus, Naue IIC-típus, Stätzling-típus)

1 Inventory number: 1993.791.II.

2 Special thanks are due to colonel Vilmos Kovács and Balázs Polgár for providing the opportunity of studying and evaluating the artefacts. I am grateful to Gábor V. Szabó, Katalin Jankovits, Tibor Bader and Csaba Bodnár for their advice and help, I am also indebted to Péter Szikits for the photographing the artefacts.

3 The macroscopic examinations were in part carried out with a digital microscope camera (Conrad Electronic, USB 9.0MP 200X). 


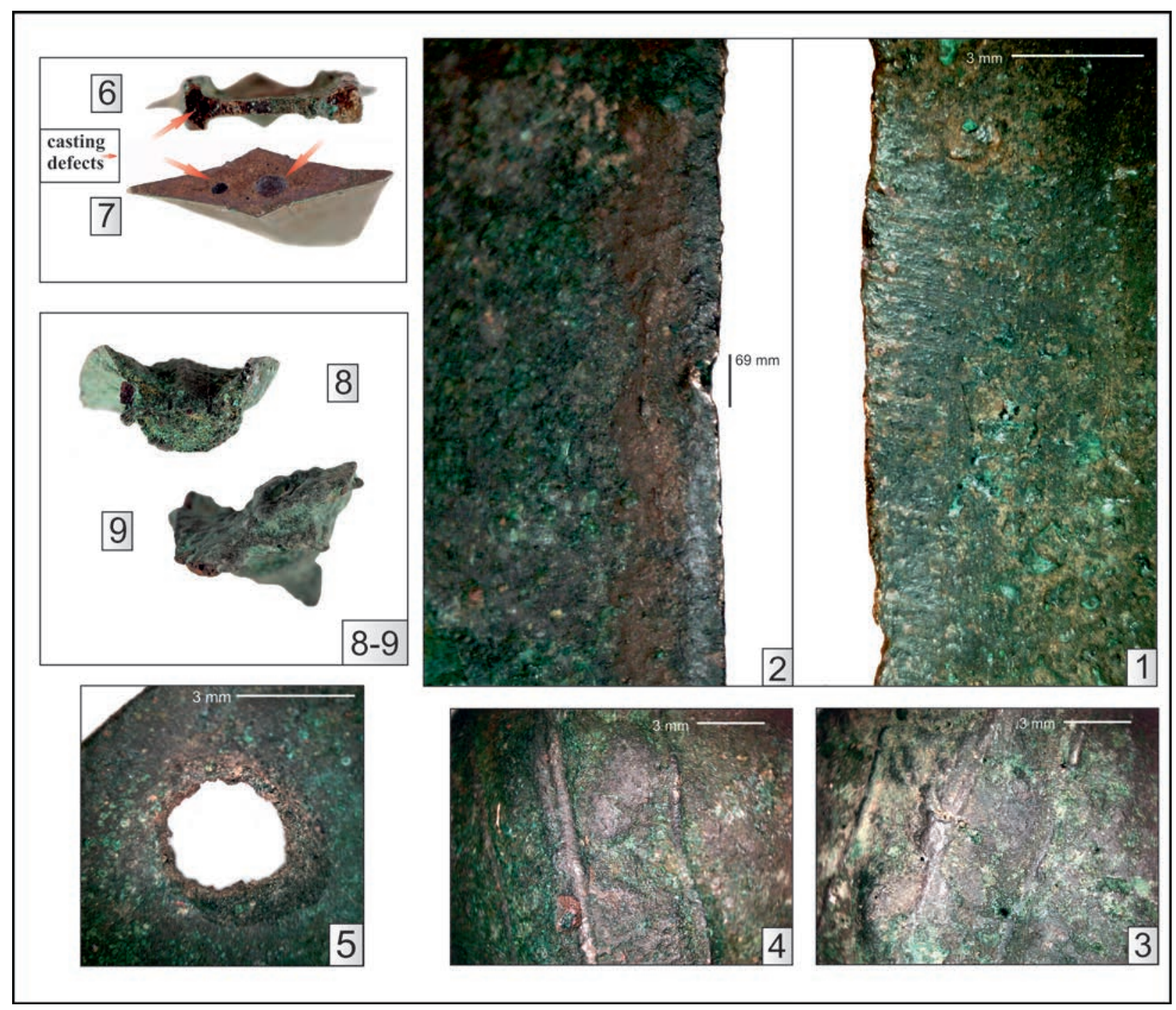

Fig. 2. Observations made during the macroscopical examination of the sword. 1: sharpening; 2: notch; 3-4: molten surface of the blade; 5: shallow abrasion traces around a rivet hole; 6-7: recent breakage surfaces; 8-9: molten blade fragments (MoD Military History Institute and Museum)

2. kép. Makroszkopikus megfigyelések a kardon. 1: élezés; 2: csorbulás; 3-4: olvadt pengefelszín; 5: vájatos kopásnyomok egy szegecslyuk körül; 6-7: recens törésfelület; 8-9: olvadt pengedarabok (HM Hadtörténeti Intézet és Múzeum)

traces of recent damage suffered after the discovery of the finds (e.g. Fig. 2.6-7, Fig. 11.1), suggesting that the original "assemblage" had probably been made up of a much higher number of objects that had been considerably less fragmented.

\section{Evaluation}

Burnt by fire: the flange-hilted sword (Fig. 14.1.1-1.4)

Based on its characteristic traits, ${ }^{4}$ the weapon can be assigned into the class of flange-hilted swords

4 Such as the extended, stretched tang with a tongue-shaped projection and ears, the narrow shoulders and the rhomboidsectioned, ribbed blade with parallel edges. with extended tang. ${ }^{5}$ This widely distributed ${ }^{6}$ weapon class goes by several different names and has been classified variously in local- and supra-regional typological schemes. ${ }^{7}$ Among these, the work of P. Schauer must be mentioned, who distinguished the most widely-accepted Stätz-

5 According to the German terminology: Griffzungenschwert mit Zungenfortsatz or Schwert mit Knaufzunge. SPROCKHOFF 1931, 21-23; Kilian-DirLmeier 1993, Abb. 1.244.

6 Sprockhoff 1931, 21-23; Kilian-Dirlmeier 1993, 102-105; HARDING 1995, 52.

7 Class 1. HAmpel 1877, 44-46, 4. kép. Group 2, swords with long, conical jet. NAUE 1903, 12-20. Swords with extended hilt. SPROCKHOFF 1931, 21-23. Erbenheim and Letten types. COWEN 1955, 73-79, Karte C. 

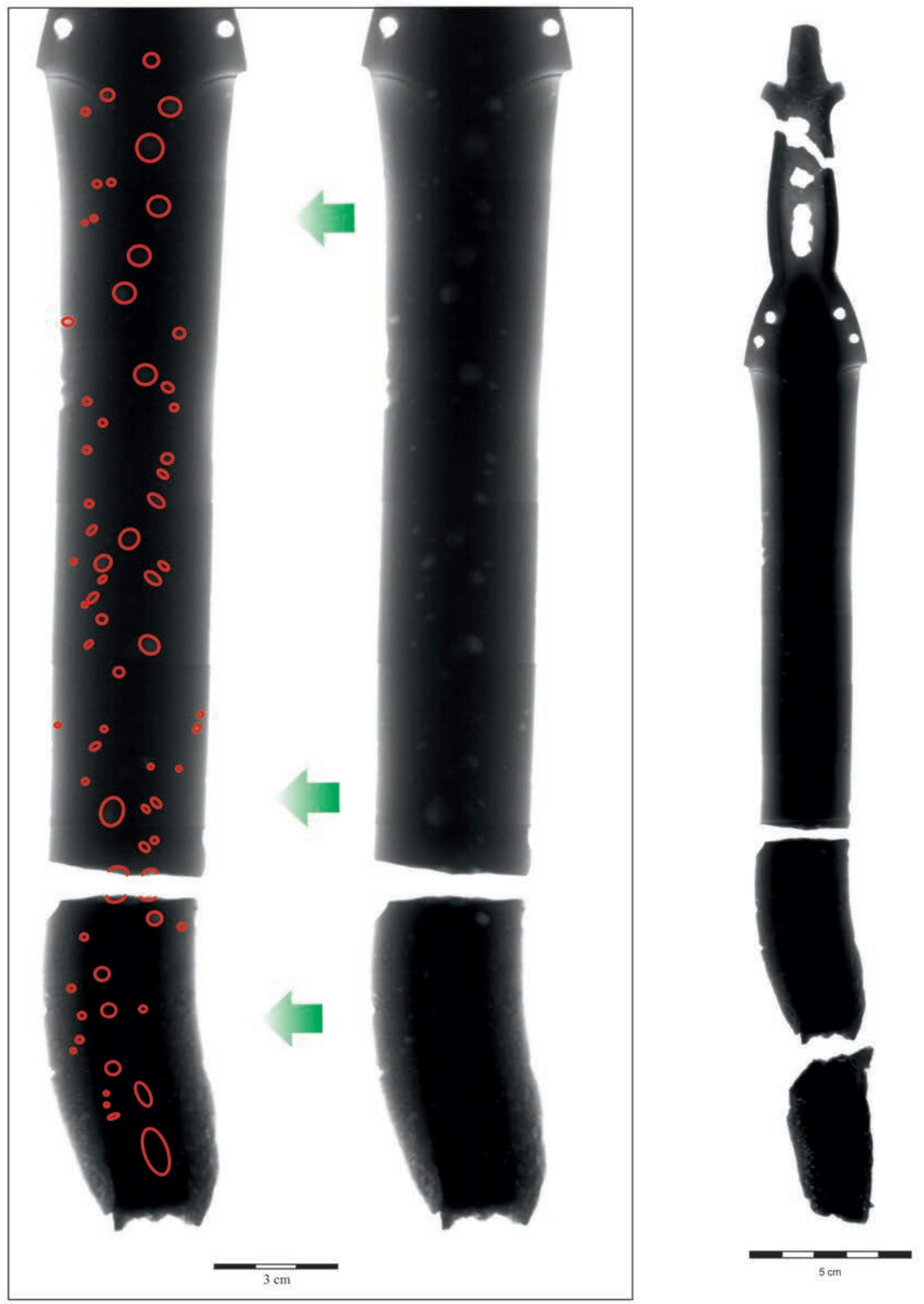

Fig. 3. X-ray images of the sword

3. kép. Röntgenfelvételek a kardról 
ling type from the Erbenheim and Letten types. ${ }^{8}$ However, Hungarian research followed a different classification: A. Mozsolics's work rested on the schemes of V. B. Peroni and J. D. Cowen (e.g. the Allerona type), while T. Kemenczei established an independent system (e.g. Type D). ${ }^{9}$ Consequently, the parallels of our sword can be found under different names, which basically all denote the same type (List I).

Surprisingly, the sword shares several common characteristics with the pieces from North Italy (Allerona type: Casale sul Sile, ${ }^{10}$ Lago Trasimeno $^{11}$ ), the Aegean (Naue II type, variant IIIC: Clauss, ${ }^{12}$ Graditsa, ${ }^{13}$ Kallithea, ${ }^{14}$ Mouliana ${ }^{15}$ ) and the Balkans (Stätzling type: Krklino/Raštani, ${ }^{16}$ Sisak ${ }^{17}$ ) (Fig. 1). Unfortunately, it is difficult to determine the date of this artefact, given that most of the closest paralles are solitary finds or parts of private collections. ${ }^{18}$ A more precise dating can be established in view of the specimens from Greece based on the chronological position of the "warrior graves" from Mouliana and Kallithea: LH IIIC. ${ }^{19}$

In the light of the above, the sword can be dated to the Ha A1 period, although it should be noted that deposition of flange-hilted swords with extended tang could have lasted for a longer period of time (e.g. Montegiorgio - Ha B1) (Fig. 13). ${ }^{20}$

In view of its recent breakage surfaces, ${ }^{21}$ the sword could have been less fragmented at the time of its deposition (Fig. 2.6-7). However, the lower third of its blade is heavily burnt and bent, moreover, some parts are detached from the main body (Fig. 2.8-9, Fig. 4.1, 3). In addition, the surface of this section is intensively blistered
(Fig. 2.3-4). It should be noted that comparable phenomena were documented on swords from cremation burials (and sometimes from hoards) suggesting that this weapon could have been melted by fire. ${ }^{22}$

Due to the above heat damages and partly to the artefact's unrestored state, the question of usage was hard to examine. Nonetheless, traces of fine sharpening ${ }^{23}$ were detected approximately $7 \mathrm{~cm}$ from the hilt, while a small nick was visible on the other side of this section (Fig. 2.1-2). The traces of abrasion around the rivet holes, which could also have been caused by its usage, are enigmatic (Fig. 2.5).

In contrast, the structure of the recent breakage surfaces of certain fragments (Cat. nos 1.1-3) was porous, indicating the weapon's inferior casting (Fig. 2.6-7). This observation called for the artefact's further archaeometric investigation. In 2014, it was possible to examine the sword and the knives of the "assemblage" with an X-ray machine in the X-ray laboratory of the Hungarian University of Fine Arts. ${ }^{24}$ The analyses were carried out by Mátyás Horváth ${ }^{25}$ and as a result of his excellent work, the intensively porous structure $^{26}$ of the blade could be ascertained. ${ }^{27}$ The casting defects were concentrated on critical parts of the blade and sometimes their size was greater than $1 \mathrm{~cm}$ (Fig. 3). In my view, these defects would have made this weapon ineffective during combat because it would simply have broken in half due to its porous structure. This assumption is supported by the fact that one of the recent breakage was taken along these porous parts (Fig. 2.6-7). ${ }^{28}$

22 E.g. KRÄMer 1952, Abb. 3.8; KemencZei 1988, 46, Taf. 19.196; KemenCZei 1991，85, Taf. 70.442.446; BRADLEY 2005, 150; Clausing 2005, 100, Taf. 8.1, Taf. 16A.1, Taf. 20.1, Taf. 37B.1, Taf. 39C.1; SCHÜtZ-BARTEL-KUNTER 2006, 36-37; NovÁKVÁCZI 2012, 99-101.

23 For similar traces see: BesL et al. 2010, 50. Abb. 7.

24 Data of the X-ray machine: Flascan 30 (package, detector table), CP 160b (X-Ray generator). Data of the records: $160 \mathrm{kV}$ (tube voltage), $0.5 \mathrm{~mA}$ (amperage), $20 \mathrm{mp}$ (exposure).

25 Grateful thanks are due to Mátyás Horváth for his excellent work.

26 Driehaus 1961, 31, Taf. 9.3; BORN-HANSEN 1991, 149-150, Abb. 3.a; BunNEFELD-SChWENZER 2011, 219, 243; MÖDLINGER 2011, 33.

27 According to B. Molloy, the improper pre-heating of the mould or its high limestone content can cause casting defects of this type. Mollor 2011, 69.

28 A similar phenomenon was documented by M. Gener during the analysis of the sword from the Ría de Huelva (Spain) hoard. GEnER 2011, 121, Fig. 3. See also MöGLINGER 2008, Fig. 2. 

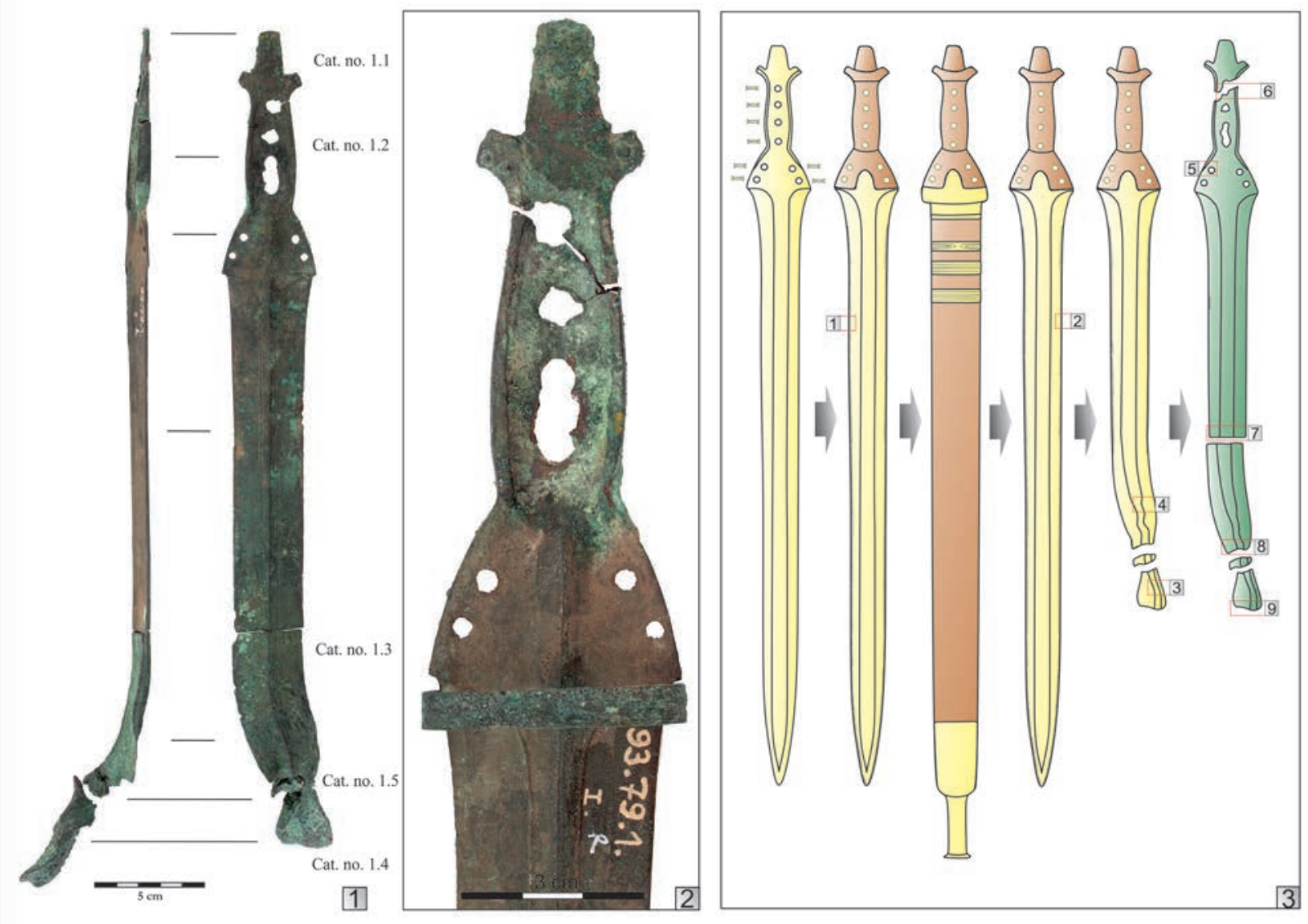

Fig. 4. 1: Reconstruction of the sword; 2: sword with the sheath part; 3: the "life cycle" of the sword (MoD Military History Institute and Museum)

4. kép. 1: A kard rekonstrukciója; 2: a kard a tokrésszel; 3: a kard „életciklusa” (HM Hadtörténeti Intézet és Múzeum)

The remain of the sheath (Fig. 14.2)

The analyzed artefacts included an oval, decorated sheet metal object. Its identification as a sheath part is suggested by its form, thickness and size (Fig. 4.2). ${ }^{29}$ It seems to me that its similarity to the pieces from Celldömölk-Sághegy, Mönlas, ${ }^{31}$ Gyöngyössolymos $1^{32}$ and SkocjanBrežec $^{33}$, suggest that it can be interpreted as decorative mount. From a typological point of view, it is difficult to classify this artefact group owing to the many individual forms. Moreover, while sheaths are rarely preserved in the Carpathian Basin, they are more frequent in the Balkans,

\footnotetext{
29 The dimensions of the objects correlate well with the cross-section of the sword, and if it is fitted onto the blade, there is plenty of space for the organic parts as well (Fig. 4.2).

30 Mozsolics 1950, 26-28; Mozsolics 2000, Taf. 17.4.

31 Clausing 2005, Taf. 42.2.

32 Mozsolics 1985, Taf. 144.19.

33 HARDing 1995, Taf. 25.204.
}

Italy, Greece, Northern Europe and the Atlantic metallurgical province. ${ }^{34}$

\section{Crumpled and deformed: the conical helmet (Fig. 15)}

Alongside the other main helmet types of the Carpatian Basin (cap-, bell-, and crested helmets), conical helmets have been continuously studied and classified since the earliest period of research. ${ }^{35}$ The type in question is believed to be

34 BADER 1991, 171-172; HARDING 1995, 98-105; WÜSTEMANNRIEDERER 2004，254-255, Taf. 107.766-801; ClAusing 2005, 40-48; HARDiNG 2007, 105-106, Fig. 15; KYTLICOVÁ 2007, 103104; MÖRTZ 2012, 171-174.

35 HAMPel 1896, 116; SPROCKHOFF 1926, 290-298; Merhart 1940; Mozsolics 1955, 46-54; Foltiny 1955, 79-81; Patay 1969, 190-193, Abb. 20; HENCKEN 1971; BORCHHARDT 1972; KeMENCZei 1979, 86-87; BouZeK 1981, 23; MAKKAY 1982, 6-22; Mozsolics 1985, 46-54; Clausing 2003b, 217; Born-HANSEN 2011, 241-244, Abb. 190-194; BRANDHERM 2011, 41, Abb. 1; LIPPERT 2011, 63-76, Abb. 18; MÖDLINGER 2013; MÖDLINGER et al. 2013. The classification into these four types and their 


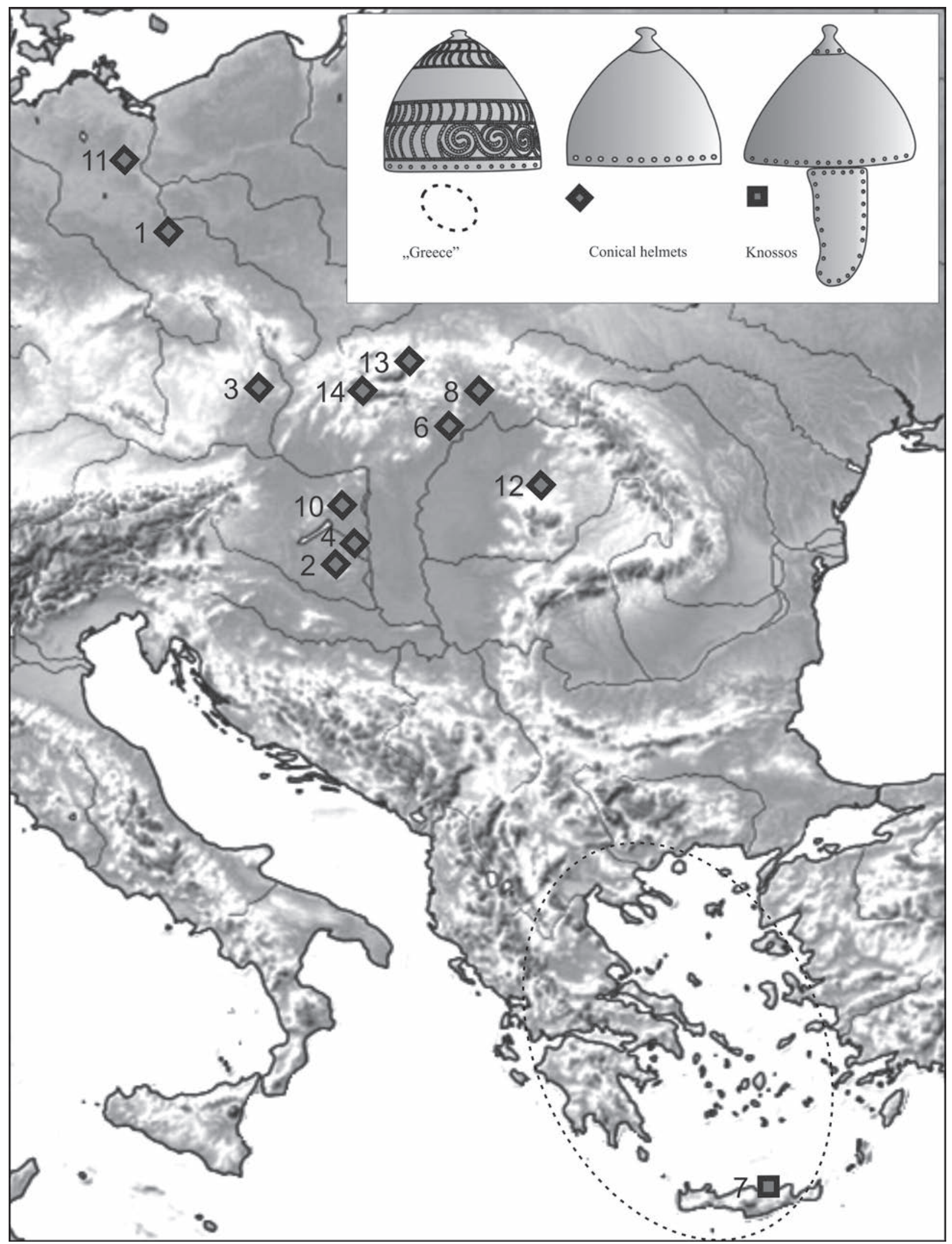

Fig. 5. Distribution of conical helmets (Mödlinger 2013, Fig. 5)

5. kép. A kónikus sisakok elterjedése (Mödlinger 2013, Fig. 5) 


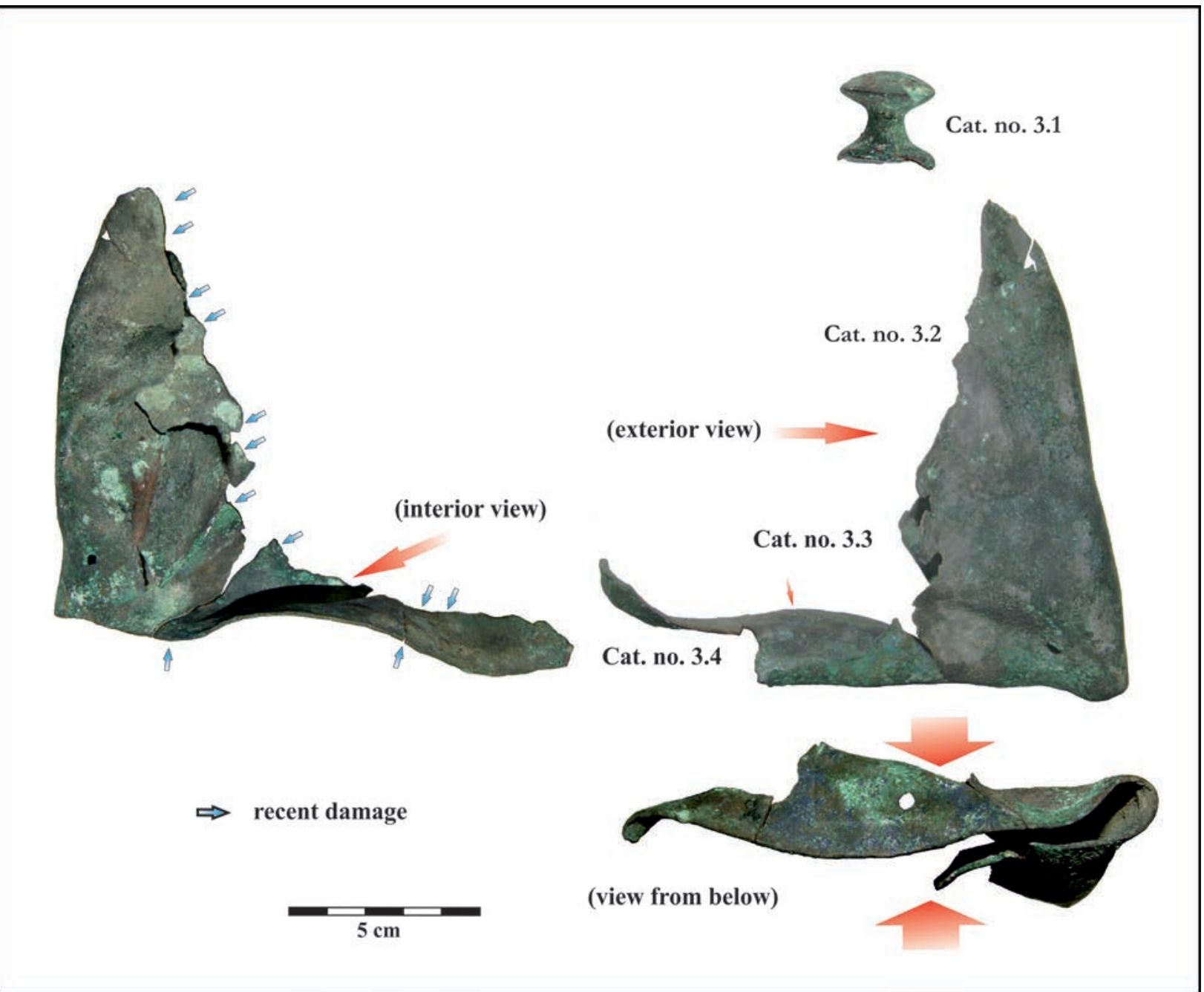

Fig. 6. Reconstruction of the crushed helmet (MoD Military History Institute and Museum)

6. kép. Az összenyomott sisak rekonstrukciója (HM Hadtörténeti Intézet és Múzeum)

one of the earliest forms of Late Bronze Age helmets in the Carpathian Basin, give that its shape and technological features are closely related to the Aegean boar tusk helmets (e. g. Dendra) and the helmet from Knossos. ${ }^{36}$ This contention was recently confirmed by a hybrid specimen whose decoration imitates that of boar tusk helmets (e.g. Dendra). ${ }^{37}$ In short, it seems that conical helmets developed from boar tusk helmets and they first appeared in the Aegean (e.g. Knossos, 15th BC), whence they later $(\mathrm{Br} \mathrm{C} 2)$ reached Central Europe (e.g. Biecz/Beitzsch, Poland). However, most of the pieces from the Carpathian Basin can be

names were criticized by G. Szabó in part for the inconsistent terminology and in part on technological grounds. SzABÓ 1994, 221-224. Nevertheless, we shall here use the label "conical helmet" due to its general acceptance in international scholarship.

36 HENCKEN 1952, 36-39; HiLler 1991-1992, 15.

37 MÖDLINGER 2013, Fig. 5. dated between the Br D and Ha A periods, except for the ones from Lúčky and Sâg, which can be assigned to the Ha B1 period (List II; Fig. 5). ${ }^{38}$ Based on the above, the helmet from the collection of the MoD Military History Institute and Museum can be dated between the above periods. However, it should be noted that it is essentially typical for the Ha A period (Fig. 13).

Currently, the helmet consists of a central knob and three other body fragments. Similarly to the sword, all of its breakage surfaces are the results of recent damage. Due to its unrestored state, we could only identify traces of hammering along its

38 Merhart 1958, 145; SNOdgrass 1967, 25-26; BorchHARDT 1972, 126, Abb. 16; CLAUSING 2003b, 217-218; LIPPERT 2011, Abb. 27; MÖRTZ 2011, 357; MÖDLINGER 2013, 400-401; MöDLINGER et al. 2013, 22, Fig. 1. 
edge (Fig. 9.2), despite the many studies on how these helmets had been made. ${ }^{39}$

At the same time, an interesting pre-depositional treatment was also observed. Based on the shape of Fragment 3.2 (Fig. 9.1), the original object was probably crumpled before its deposition, which made its later re-use impossible (Fig. 6)..$^{40}$

\section{The pair of Pergine: the greaves}

(Fig. 16, Fig. 17.5.1-5.12, 4/5.1.1-4/5.12)

The greaves belong to a special Late Bronze Age defensive weapon group whose principal distribution area was Transdanubia, the Alpine region, North Italy and the Aegean. ${ }^{41}$ The earliest specimens were found at Dendra, which were chronologically followed by the pieces from Kallithea, Enkomi and the Acropolis of Athens. ${ }^{42}$ However, it is not at all certain that the pieces from the Carpathian Basin can be derived from the Aegean. Some scholars believe they developed independently, while others, like W. Dehn, assume a common origin. ${ }^{43}$ It seems quite likely that the organic predecessors pre-dated their metal variants in both regions. ${ }^{44}$

Regarding their typology, several different formal and stylistic groupings have been proposed for greaves, of which we here follow $\mathrm{Ch}$. Clausing's scheme, who classified the main groups and variants according to how they were fastened and their finer stylistic features. ${ }^{45}$

39 Szabó 1994, 223-224; HAnsen 2008, Abb. 20; MöDlinger et al. 2013, 32-34; MÖDLINGER 2013, 393.

40 The method of crushing was identified by the fact that the rivet holes were punched inward from the exterior along the edge of the helmets (Fig. 9.1). MöDLINGER et al. 2013, 33.

41 DeHn 1980, Abb. 9; KRAHe 1980, 76-77, Abb. 57; BouZeK 1981 30; SCHAUER 1982, Abb. 19; HANSEN 1994, 13, Abb. 5; JANKOVITS 1997, 17, Fig. 10; HARDING 2007, 79. The latest graves were unearthed at Várvölgy and Lengyeltóti. HoRvÁTH 1997, 1. kép, 4. kép; MÜLlER 2006, 234-235, 4. ábra.

42 Merhart 1958, Abb. 1; Müller-Karpe 1962, 275; Verdelis 1967, 35, Abb. 8, Beilage 19, 1-3; BOUZEK 1981, 28; SCHAUER 1982, 147-152; Harding 1984, 179-180; MounTJOY 1984, 135 137; ClaUSING 2003a, 171.

43 MÜller-Karpe 1962, 276; Dehn 1980, 29.

44 SNODGRASS 1967, 30, Fig. 10-11; BouZeK 1981, 28-30, Abb. 7. It is quite possible that the metal greaves had been attached to organic (leather) parts by riveting or lacing. Some scholars have argued that greaves were symbolic objects or items of social display. In my view, if these flexible sheet metal objects were combined with strong organic parts, they would have been able to withstand the blows of offensive weapons. However, further experimental research is needed to prove this assumption. DeHn 1980, 32; HANSEN 1994, 13; KRAHE 1980, 77.

45 Merhart 1958; Mozsolics 1972, 387, 390; Schauer 1982, 101-151, 133-141; JANKOVITS 1997, 1-12, 16-17; Mozsolics 1985, 27; Clausing 2003a, 149-185.
According to this grouping, the greaves can be assigned to Group 1, Variant A2, which was principally distributed in the Carpathian Basin (e.g. Bodrogkeresztúr, ${ }^{46}$ Bonyhád area, ${ }^{47}$ Brodski Varoš, ${ }^{48}$ Esztergom-Szentgyörgymező, ${ }^{49}$ Nadap,${ }^{50}$ Poljanci $1^{51}$ ) and in Austria (Brandgraben ${ }^{52}$ ), although specimens of this type are known from France (Cannés-Écluse $2^{53}$ ) and Italy (Desmontá, ${ }^{54}$ Malpensa, ${ }^{55}$ Pergine $^{56}$ ) as well (List III; Fig. 7). ${ }^{57}$ The greaves from Pergine (Italy, Trentino) must here be mentioned owing to their formal characteristics (e.g. the elongated oval shape, metal wire lace, similar length), and decorative techniques; moreover, their ornamental motifs are almost wholly indentical to the pieces discussed here. ${ }^{58}$ The similarities between these objects are so close that further comparative archaeometric analyses would be essential in the future.

Despite the good parallels to the greaves their chronological position is not entirely clear. According to both P. Schauer's and Ch. Clausing's schemes, the parallels of the Pergine greaves come from Ha A1 assemblages. ${ }^{59}$ However, the graves from Pergine were not accompanied by further well-datable artefacts therefore could the assemblage only be dated on stylistic ground. ${ }^{60}$ G. Fogolari first assigned them to the Iron Age (Benacci II, Arnoaldi) based on their decoration, which could be associated with Villanova artefacts. ${ }^{61}$ According to the stylistic development outlined by G. von Merhart, the repoussé patterns made up of larger bosses and the stylized bird representation date the Pergine find to the Ha B period. ${ }^{62}$ His dating is in line with the chronological scheme proposed by A. Jockenhövel, who pointed out the similarities between the Pergine greaves and the patterns on ProtoVillanova ceramics (e.g. Bismantova, Monteleone di Spoleto, Pianello) and the fibulae from the

46 Kemenczei 2003, Taf. 7.19.

47 WOSINSKY 1890, 12, 15.

48 VinSKI-GASPARINI 1973, 212, Taf. 55.221.

49 JANKOVITS 1997, Fig. 5.

50 MAKKAY 2006, 4. tábla.

51 VINSKI-GASPARINI 1973, 218, Taf. 48.19.

52 WindHOlZ-KONRAD 2008, Abb. 53.

53 GraUCHER-RoberTs 1967, 205, Fig. 46-48.

54 SALZANI 1985, 42.

55 Mira BONOMI 1979, 125, Fig. 1.1-2.

56 Fogolari 1943, 73, Abb. 1-4.

57 Clausing 2003a, 154-158.

58 FogOlari 1943, 73-74, Abb. 1-4.

59 SCHAUER 1982, 134-137; Clausing 2003a, 154-158.

60 These finds were dated between the 12th-11th century BC and the 8th-7th century BC. ClaUsING 2003a, 158; JANKOVITS 1997, 14.

61 Fogolari 1943, 80-81.

62 Merhart 1958, 102-105, 115-117, 132. 


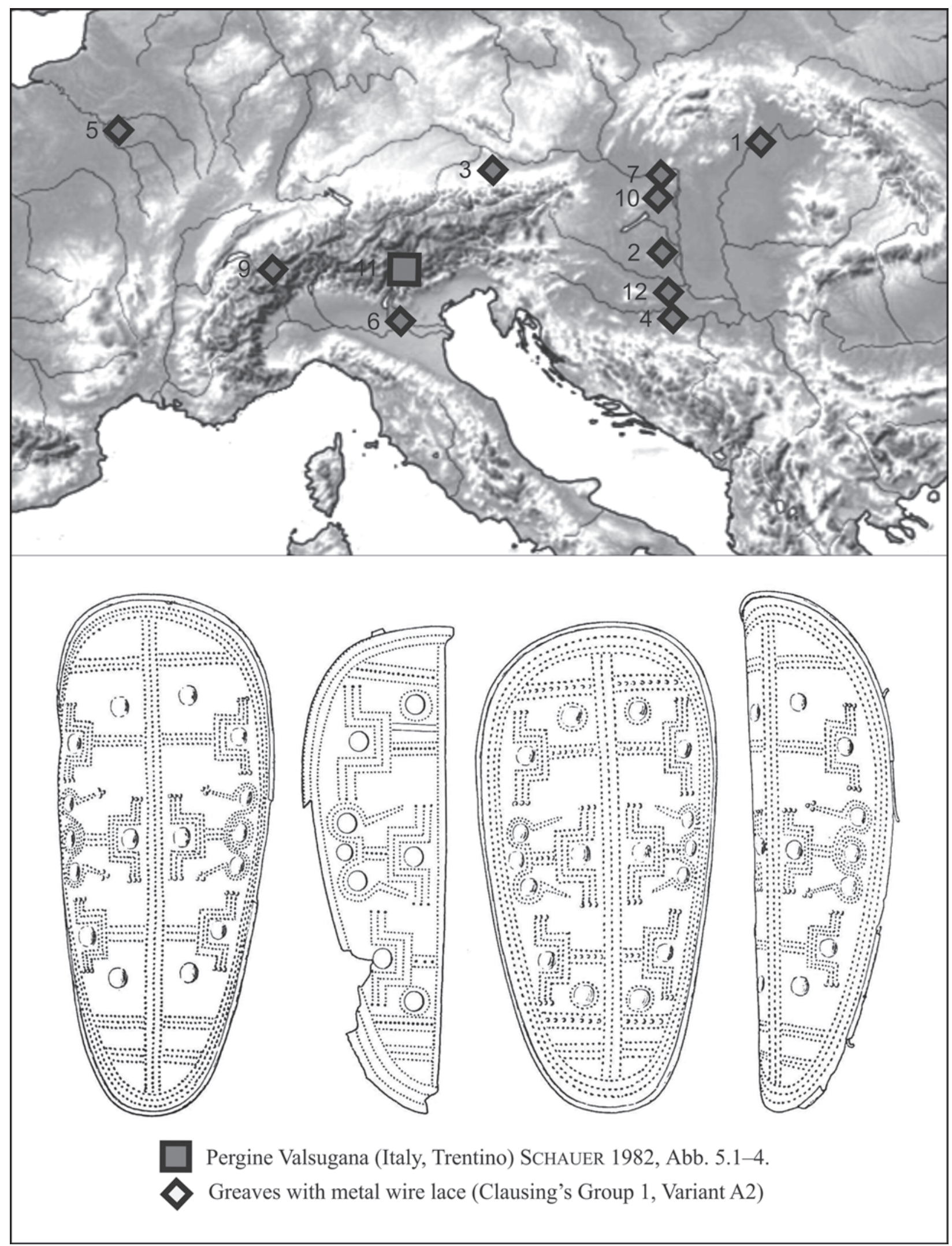

Fig. 7. Distribution of greaves (Group 1, Variant A2)

7. kép. A lábszárvédók elterjedése (1. csoport, A2 variáns) 


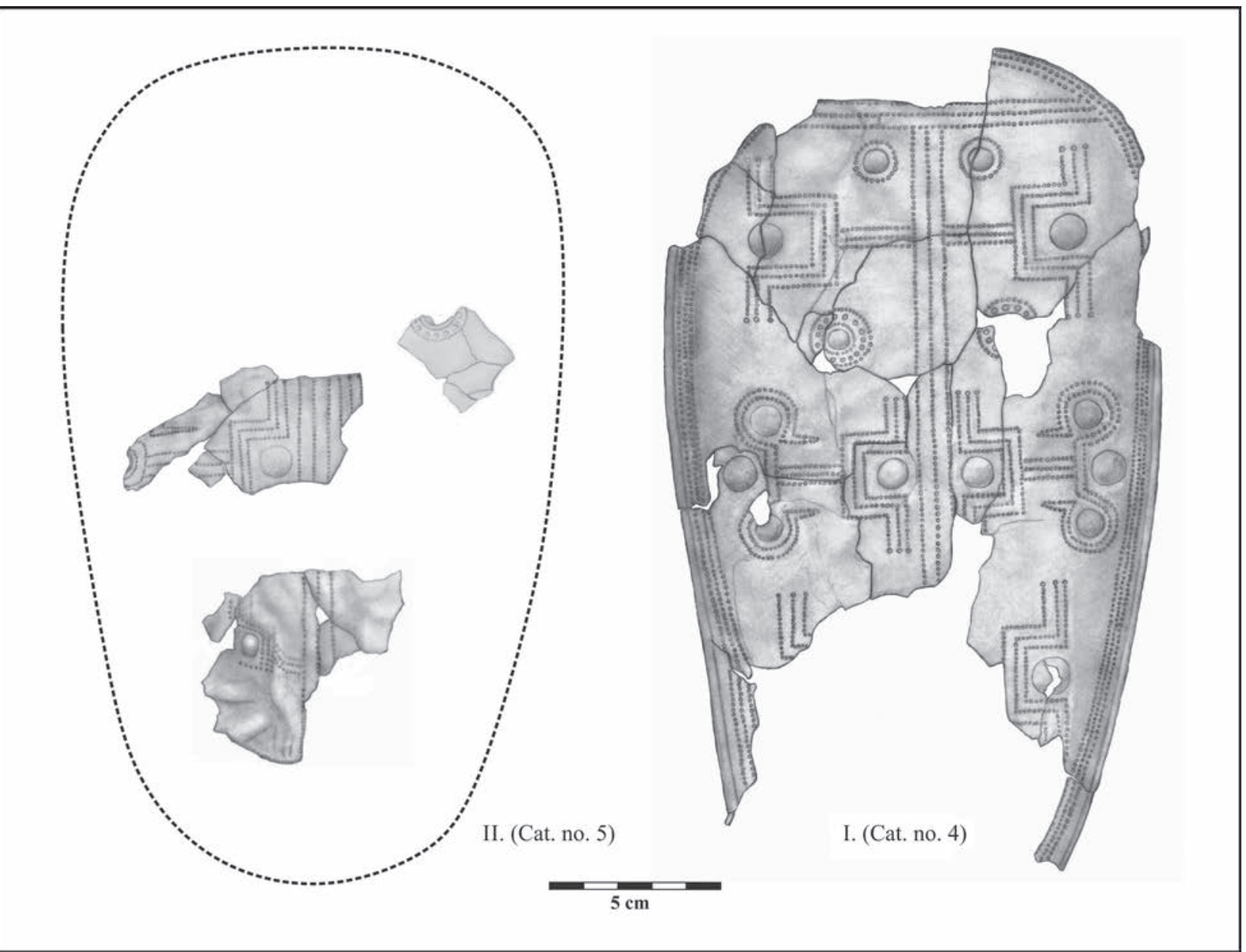

Fig. 8. Reconstruction of the greaves

8. kép. A lábszárvédők rekonstrukciója

Tolfa-Coste del Marano hoard (10th century BC - Ha B1/IV period). ${ }^{63}$ Later, a similar dating was proposed by Franco Marzatico as well. ${ }^{64} \mathrm{New}$ data were provided by G. Zipf's stylistic analysis who demonstrated that the VOB3 ${ }^{65}$ and VOB4 ${ }^{66}$ motifs had been used over a long period of time, from the Bronzo Finale 2/3 (VOB3) to the Bronzo Finale 3-Primo Ferro 1A-1B (VOB4). ${ }^{67} \mathrm{Un}$ fortunately, the undocumented context of the assemblage from the collection of the MoD. Military Institute and Museum is of little help in clarifying the exact date of Pergine finds. Consequently, based on the dating of its parallels, it can be assigned to the Ha A1 period and a later date (Ha B1) can only be supported by stylistic analysis (Fig. 13). ${ }^{68}$

63 JocKenHÖVEl 1974, 83-84, Taf. 19.1, Taf. 20.1-2, Taf. 21.2-5.

64 MARZATICO 2000, 402.

65 ZIPF 2003, 452.

66 ZIPF 2003, 463

67 ZIPF 2003, 452-455, 463-467, Tab. 39, Tab. 41.

68 In my view, the later dating of the Pergine finds needs further confirmation. The stylistic "evolution" from realistic to more
The greave pair (1: Cat. no. 4.1-12; 2: Cat. no. 5.1-12.) and the other five larger fragments were reconstructed from 37 smaller fragments with the help of the Pergine finds (Fig. 8). ${ }^{69}$ Similarly to the sword and the helmet, all breakage surfaces of the greaves were recent. This excludes the possibility of deliberate prehistoric fragmenta-

abstract bird depictions and the appearance of repoussé design with larger bosses do not necessarily imply significant chronological changes. ClAUSING 2003a, 154-158. For instance, the combination of different stylistic types is known from the archaeological record (e.g. Nadap). MAKKAY 2006, Pl. II.2, Pl. III.3, Pl. IV.4-5. Moreover, most of the parallels of the Pergine find can be dated to the Ha A. Finally, the repoussé decoration pre-dated the Ha B1, as shown by Žatec type buckets and Blatnica type cups. PATAY 1990, 53-54; CLAUSING 1996, 426.

69 Fogolari 1943, 73, Abb. 1-4; SCHAuer 1982, 134, Abb. 5. The unrestored state of the object made it impossible to examine the greaves' finer details (e.g. the number of the repoussé dots making up the design could be much higher). Therefore, the reconstruction presented here is no more than an illustration and a new reconstruction should be made after the restoration of the objects (Fig. 8). 

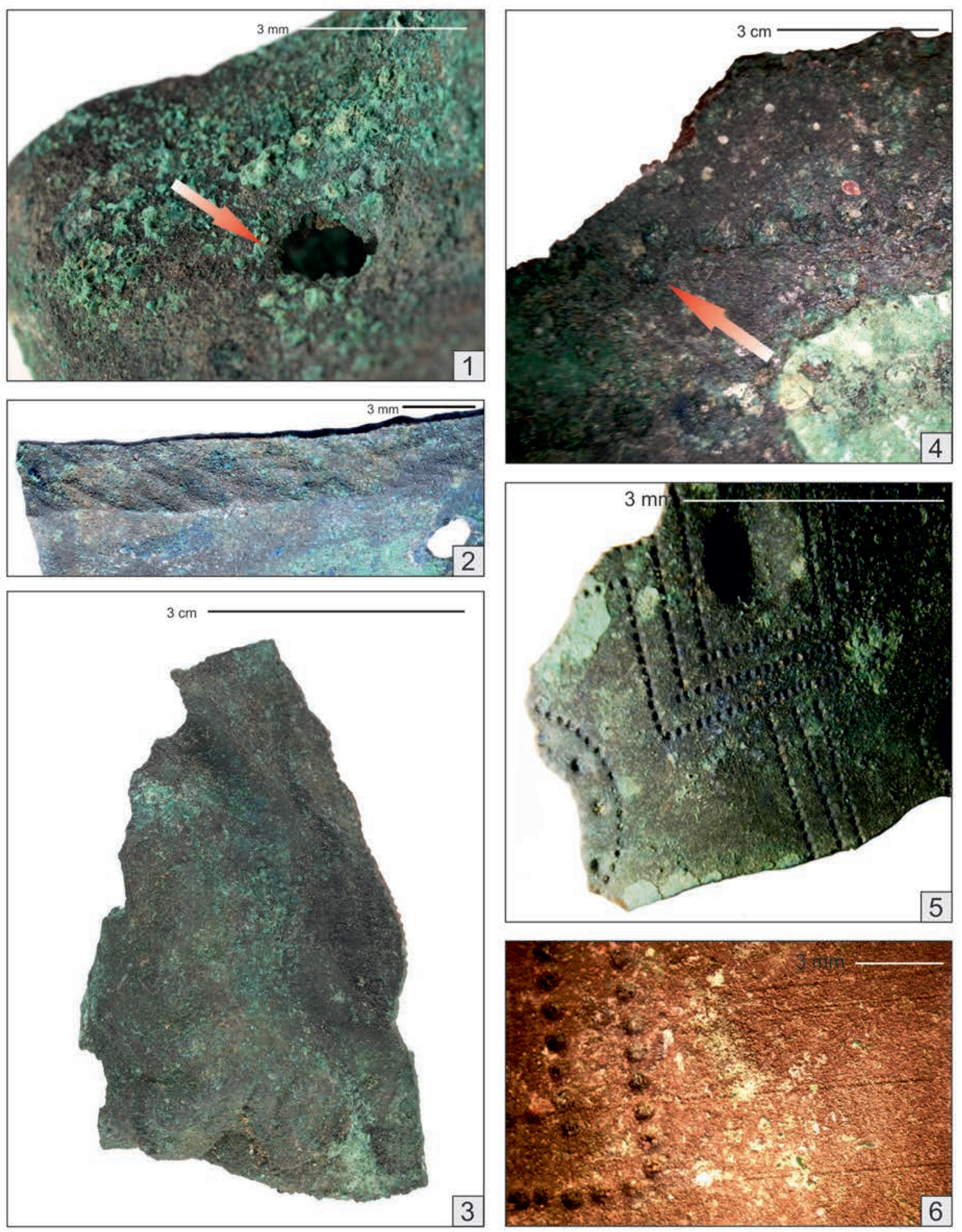

Fig. 9. Observations made during the macroscopical examination of the helmet and the greaves. 1: The position of the rivet hole's perforation on the helmet; 2 : hammering traces along the edge; 3 : the molten surface of the fragment $5.11 ; 4$ : imprecise punching on the greave 4.1; 5-6: incised "guiding" lines on the reverse of the greave fragment 4.1 (MoD Military History Institute and Museum)

9. kép. Makroszkopikus megfigyelések a sisakon és a lábszárvédőkön. 1: A szegecslyuk beütési helyzete a sisakon; 2: kalapálásnyomok a sisak peremén; 3: az 5.11. töredék olvadt felülete; 4: pontatlan poncolásnyom a 4.1 lábszárvédő-töredéken; 5-6: bekarcolt segédvonalak a 4.1. lábszárvédő-töredék hátulján (HM Hadtörténeti Intézet és Múzeum) 


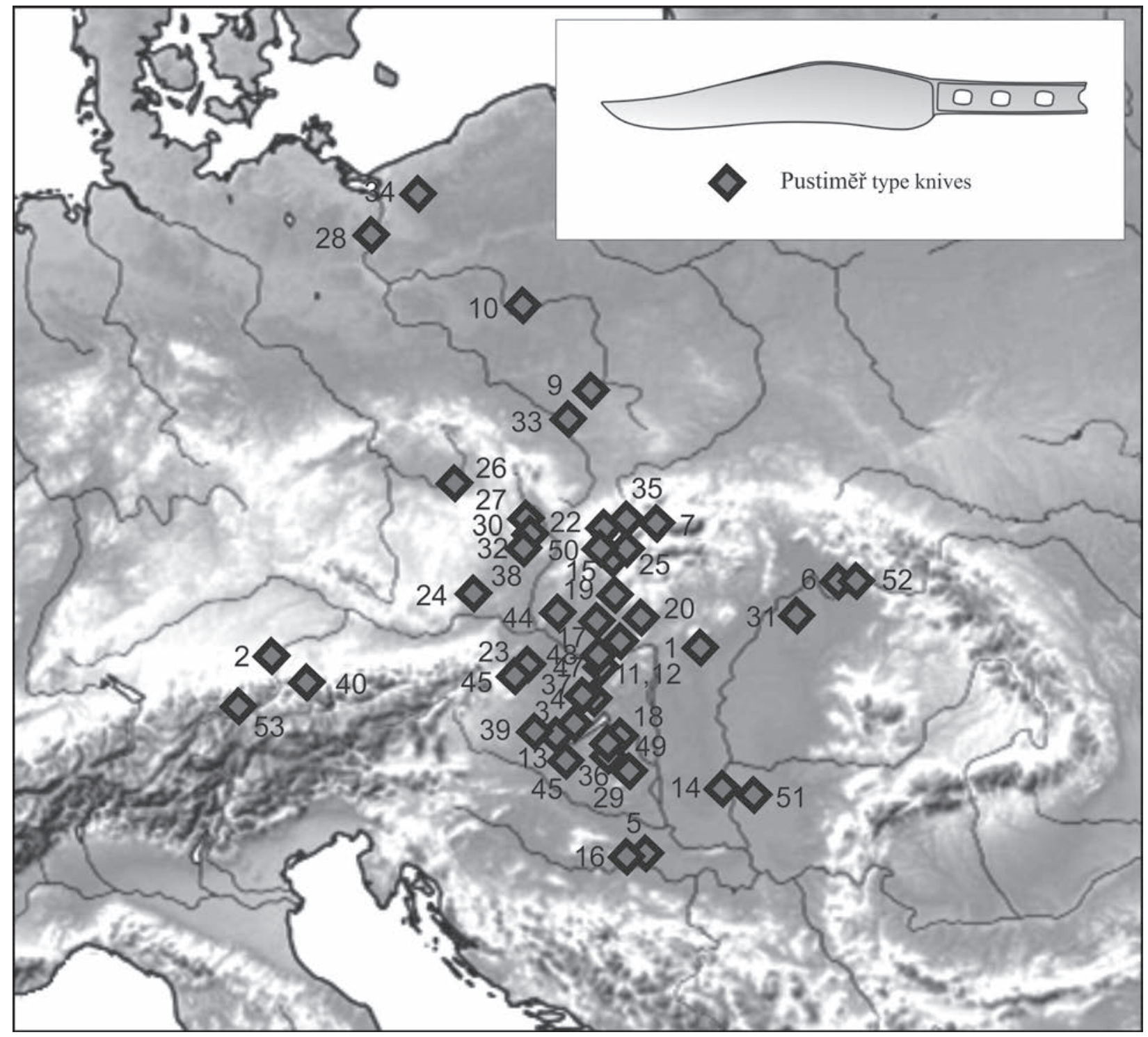

Fig. 10. Distribution of Pustiměř-type flange-hilted knives

10. kép. A Pustiměř-típusú nyélnyújtványos kések elterjedése

tion which was documented in the case of other similar finds (e.g. Cannes-Écluse, ${ }^{70}$ Poljanci $4^{71}$ ).

Nonetheless, the surface of certain fragments (Cat. nos. 4/5.1.1, 3.1, 3.4) was blistered and their ornamental design was almost completely melted, probably as a result of intensive heat damage (Fig. 9.3). Regarding its decorative techniques, an imprecise repoussé pattern (Fig. 9.4) and lightly incised lines (width: $0.0582 \mathrm{~mm}$ ) were noted on the reverse of the objects (Fig. 9.5-6). The latter can be interpreted as lines used as a guide because they conform to the decorative pattern and probably aided the craftsman in creating symmetric design. ${ }^{72}$

\section{Broken, bent, molten: the flange-hilted knives}

(Fig. 18.6.1-8)

Owing to individual form (Cat. no. 6) and untypical condition (Cat. no. 8) the classification of the three flange-hilted knives is uncertain (Fig. 18.6.1-6.2, 8). Another problem is that more recent typologies for the knives of the Carpathian Basin have only been established for Slovakian 


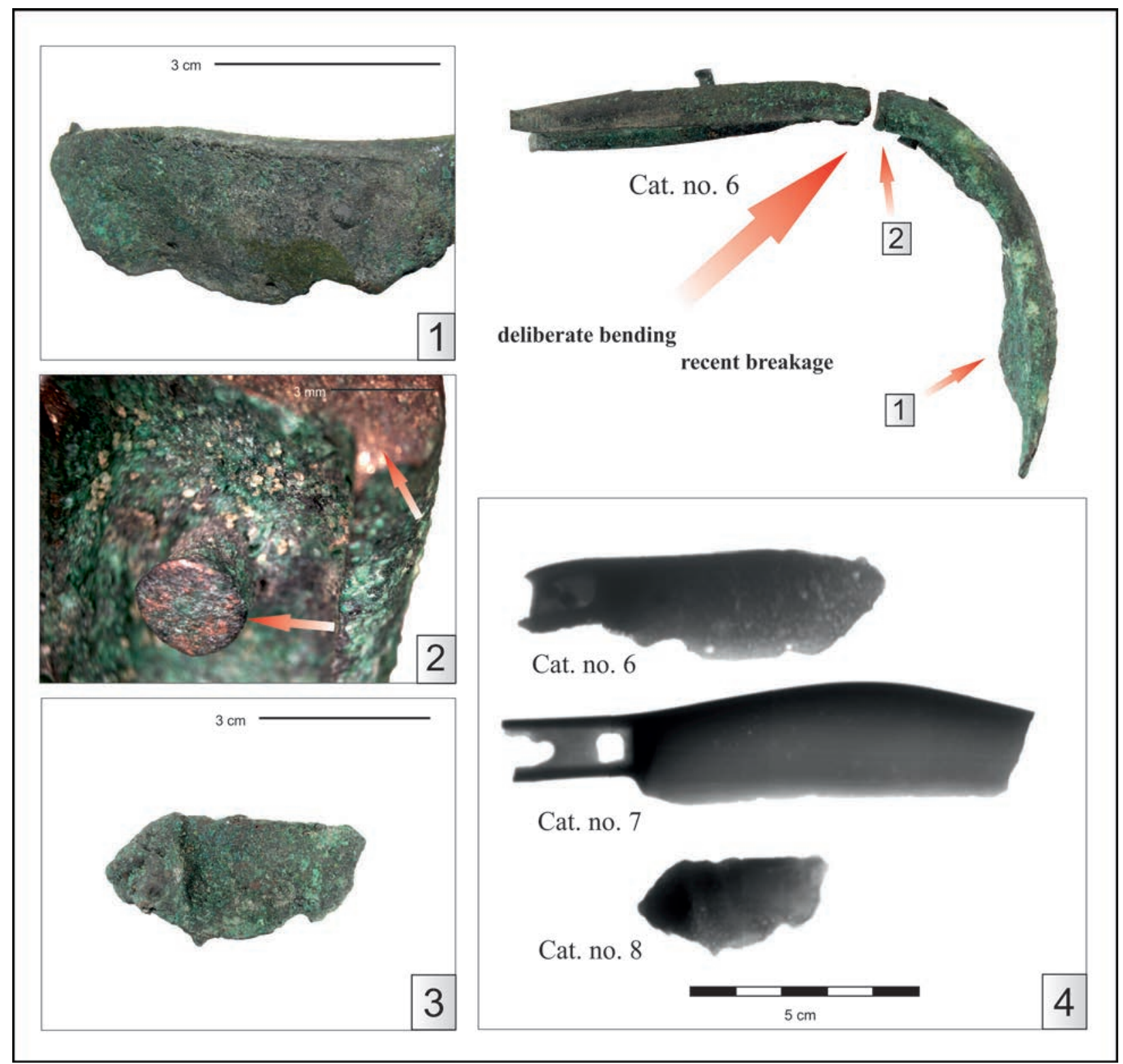

Fig. 11. Observations made during the macroscopical examination of the knives. 1: Molten blade; 2: recent breakage surface and hammered rivet head; 3: molten knife (Cat. no. 8); 4: X-ray images of the knives (MoD Military History Institute and Museum)

11. kép. Makroszkopikus megfigyelések a késeken. 1: Olvadt penge; 2: recens törésfelület és kalapált szegfej; 3: olvadt kés (8.); 4: röntgenfelvételek a késekről (HM Hadtörténeti Intézet és Múzeum)

knives, therefore the following evaluation partly rests on Western and Northern European schemes and it is also limited by the quality of the previous publications of finds from the Carpathian Basin. ${ }^{73}$

From a typological point of view, one knife (Cat. no. 7) has well identifiable features: a straight hilt base, a curved back, a straight blade

73 Hampel 1896, 58-59; Foltiny 1955, 98-101; BRUNN 1968, 152 154; Ř́́lHOvsKÝ 1972; PerONi 1976; Gedl 1984; Mozsolics 1985, 40-42, Taf. 277-278; HANSEN 1994, 219-226, Abb. 139-143, Abb. 144; JiRÁŇ 2002; CHEBENOVÁ 2012; VELIAČIK 2012.
(Fig. 17.7). Comparable pieces can be found among the Pustimerr type flange-hilted knives, which were primary distributed in Eastern Bohemia and the Carpathian Basin, although they also appear in Western and North Central Europe (List IV, Fig. 10). ${ }^{74}$ It should be noted that the dating and grouping of this type are not uniform. ${ }^{75}$ According to F. Kószegi, they appeared in Phase I

\footnotetext{
74 Ř́́HOvsKÝ 1972, 32-33; GedL 1984, 32; KoBAL' 2000, 48-49.

75 Chebenová 2012; VeliačiK 2012.
} 


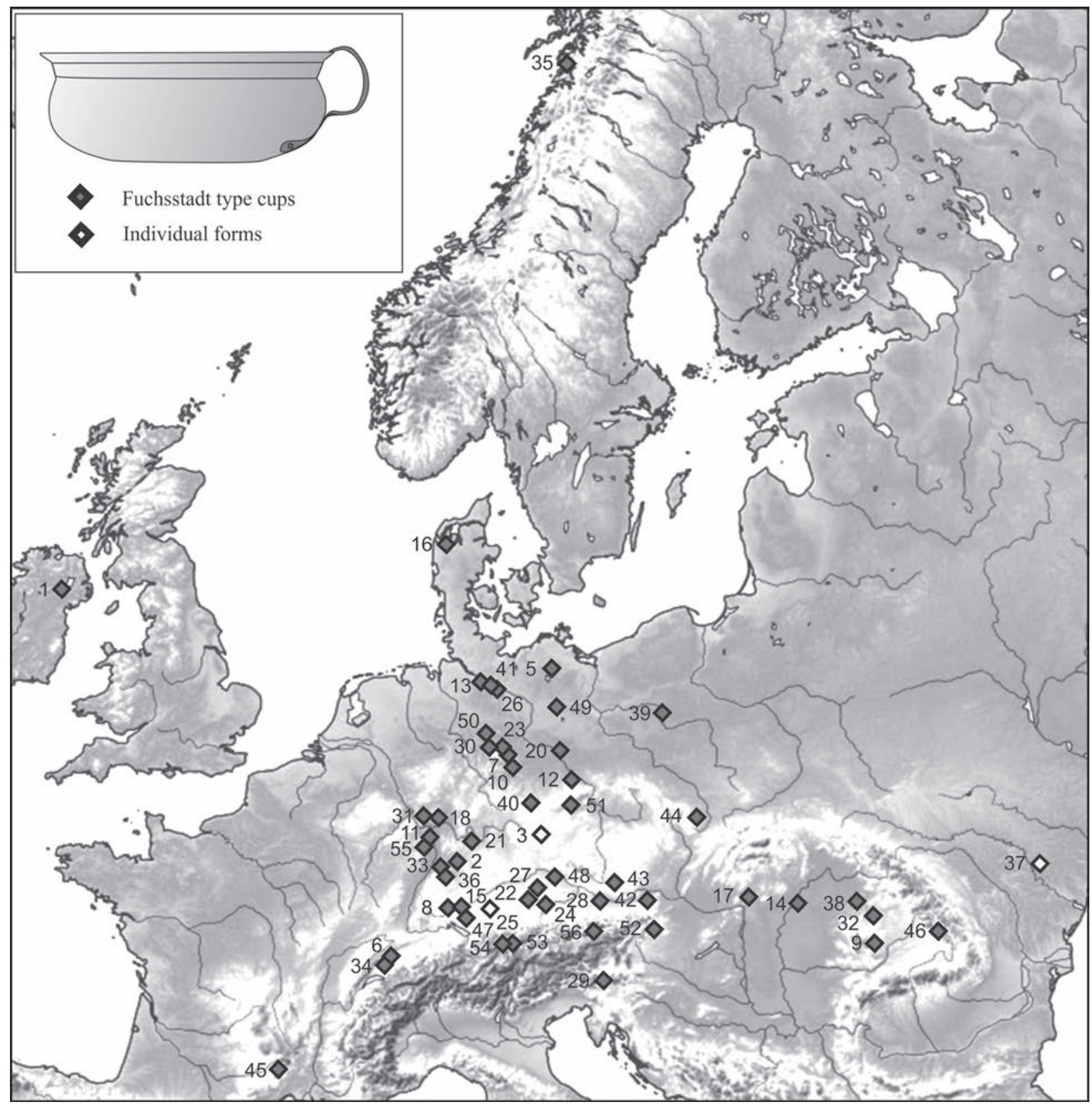

Fig. 12. Distribution of Fuchsstadt type cups

12. kép. A Fuchsstadt-típusú csészék elterjedése

(Br C-D). ${ }^{76}$ The Czech examples were dated to the Ha A1 period, the Slovakian pieces to Ha A and the ones from Poland to Period IV (Ha A2-Ha B1). ${ }^{77}$ This is rooted in the rather controversial classification of the "Pustimerr type" which comprises many individual objects (e.g. the piece from Kirchen am Wagram has a heart-shaped base $^{78}$ ) as well as in frequent overlaps with other

76 KószegI 1988, 26, 35.

77 Ř́́ínovsKÝ 1972, 33; GedL 1984, 31-32; CheBenová 2012, 14; VELIAČIK 2012, 297-299, 339, Obr. 4.

78 ŘíHOvSKÝ 1972, Taf. 9.106. major types (e.g. the Baierdorf, Novy Seč, and Nový Vestec types). ${ }^{79}$ Consequently, only the chronological position of the closest parallels, which can be associated with the Ha A1, could be considered when dating this knife (Fig. 13).

The classification of another knife (Cat. no. 6) is even more controversial than the previous one due to its melted state and individual decoration

79 ŘíinovskÝ 1972, 32-33, Taf. 9.102.105; PerONi 1976, 13-14, Tav. 2.13; JiRÁŇ 2002，31-32; MÜller-KarPe 1959a，135，268; MÜLLER-KARPe 1959b, Taf. 105.1; VeliaČIK 2012, Obr. 4.1-9. 


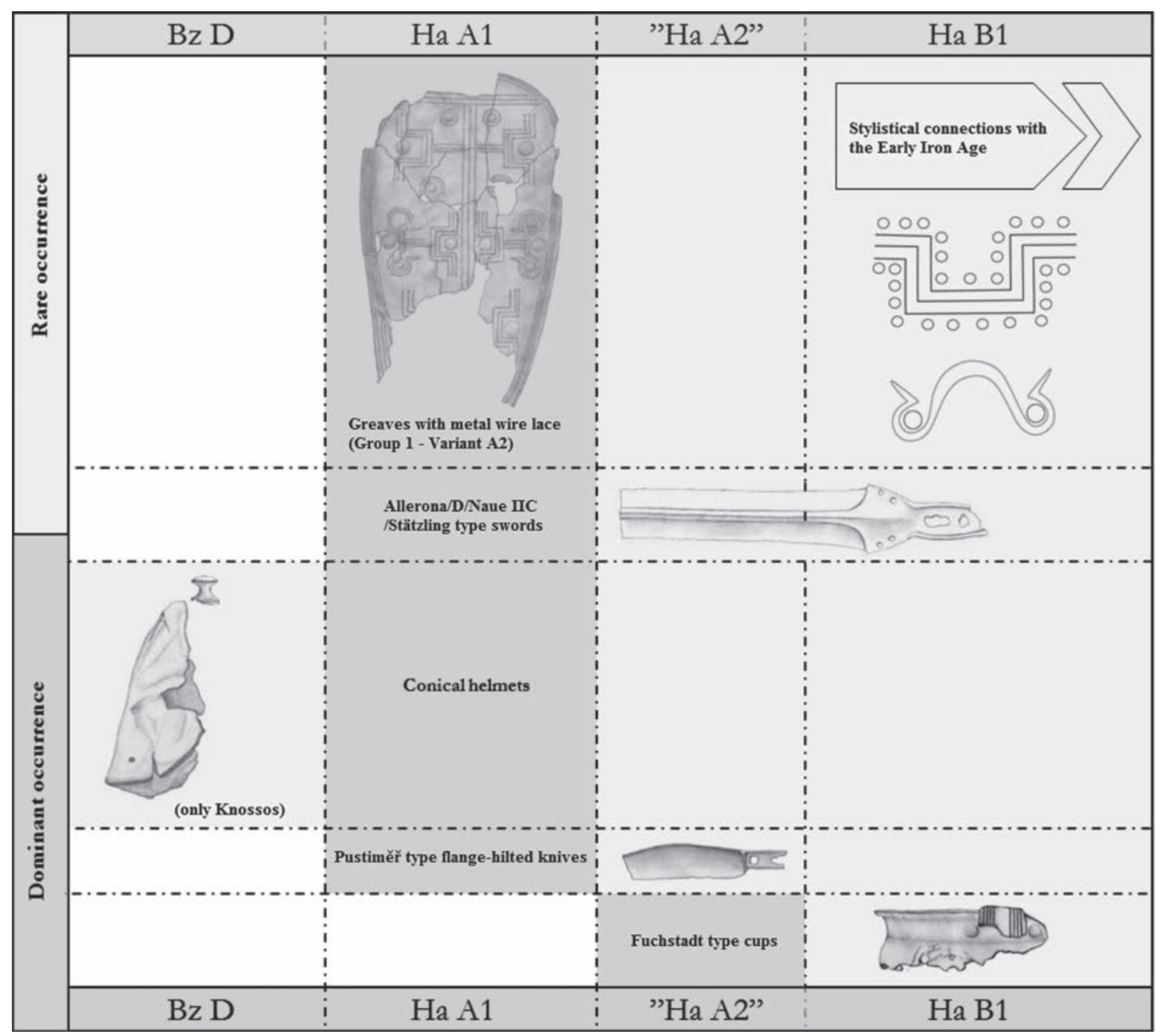

Fig. 13. Chronological position of the finds

13. kép. A leletek időrendi helyzete

(Fig. 18.6.1-2). Its formal characteristics such as the swallow-tailed base of its hilt is specific to several different types (Pustiměr̆, Malhostovice, Hradec and Dašice types). ${ }^{80}$

Similarly to the other artefacts of the "assemblage", the breakage surfaces of the three flange-hilted knives were recent except from the broken blade of the knife described under Cat. no. 7 (Fig. 11.2). As had been documented in the case of the sword and the greaves, the three knives were also damaged by heat (Fig. 11.6, 8). The blade of one specimen (Cat. no. 6) was bent and partly molten (Fig. 11.1). However, the most

80 Ř́íHOvSKÝ 1972, 29-36. A similar object has been found in the Grave 68 of the Unterhaching cemetery. MÜLLER-KARPE 1959a 301; MÜLLER-KARPE 1959b, Taf.187.F.1. intensive heat damage was observed on the knife described under Cat. no. 8, which was almost completely melted by fire (Fig. 11.3). The small blisters caused by heat damage were also visible on the X-ray images (Fig. 11.4).

\section{Fuchsstadt type cup from the West (Fig. 17.9)}

Even though the greater portion of the cup is missing, the surviving fragment can be confidently assigned to the group of Fuchsstadt type cups. ${ }^{81}$ The characteristics of this low vessel type, as defined by E. Sprockhoff, are the straight rim,

81 Similarly to the others, the breakage surfaces of the object were also recent. 
the funnel-shaped neck, and the ring-footed base with an omphalos, and the decorated loop handle attached with conical-headed rivets. ${ }^{82}$ In line with this definition, many comprehensive studies have provided new data on this artefact class. Surprisingly, both J. Thrane, Ch. Jacob and J. Martin pointed out that the sphere of the socalled Fuchsstadt type cups is not homogenous and that many regional variant and hybrid form existed simultaneously. ${ }^{83}$

Regarding the distribution of Fuchsstadt type cups, they are characteristic in West Central Europe, especially in the region of the Danube, the Rhine and the Main rivers. ${ }^{84}$ They mostly appeared among the grave goods of "warrior graves" or as parts of feasting set hoards (e.g. Dresden-Dobritz) ${ }^{85}$ Interestingly enough Fuchsstadt type cups have also been found outside their main distribution area. Specimens are known from Northern Europe and the Carpathian Basin, but even from Ukraine and Ireland (List V; Fig. 12). ${ }^{86}$ These cups are generally dated to the Ha A2 period in Western Europe, while the pieces from the Carpathian Basin were deposited in Ha B1 hoards (Fig. 13). ${ }^{87}$

\section{Wagon model part? (Fig. 18.18)}

A ribbed tube was also a part of the "assemblage". Due to its uncommon form, the exact function of this object cannot be determined. However, its form and decoration strongly recall the axles of wagon models. ${ }^{88}$ At present, I am not aware of identical or similar objects either from the Carpathian Basin, or from Western Europe.

\section{Sheet metal fragments (Fig. 17.10.1-17)}

In addition to the above described objects, the "assemblage" contained eight sheet metal fragments. Based on their dimensions, they cannot

82 SPROCKHOFF 1930, 67-77, Taf. 19; PATAY 1990, 57; PRÜSSING 1991, 22; PATAY 1996, 408; GEDL 2001, 16; SOROCEANU 2008, 45; MARTIN 2009, 53.

83 Thrane 1975, 136-137; JACOB 1995, 23-31, Taf. 80.B; MARTiN 2009, 54-62, Anghang 2/Liste 2. The closest parallels of the cup discussed here is hard to determine due to its fragmentary state and common handle decoration.

84 SPROCKHOFF 1930; PRÜSSING 1991, 23; MARTIN 2009, 58-59.

85 SOROCEANU 2008, 49; MARTin 2009, 58-59.

86 Childe 1948, Fig. 8; Patay 1990, 58, Taf. 79; JaCOB 1995, Taf. 80B; PATAY 1996, Abb. 3; GEdL 2001, 7.

87 MÜller-Karpe 1959a, 158-159; Thrane 1975, 137; Patay 1990, 58; PRÜSSING 1991, 23-24, Taf. 150; HANSEN 1994, 116; JACOB 1995, 31; SALAŠ 2005, 56-57; SOROCEANU 2008, 50.

88 Vosteen 1999, 80-81, Taf. CVIII-CXII; PARe 2004, Abb. 6; SOROCEANU 2008, 217-223, Taf. 399-400. be associated with the greaves or the cup, and were therefore probably part of a third metal object. ${ }^{89}$

\section{The chronological position of the artefacts}

Due to the undocumented find context and the lack of other data, the dating of the "assemblage" is uncertain. All the objects bear traces of recent damage indicating that the objects making up the "assemblage" may originally have been more intact at the time of their deposition. In addition, it is possible that the surviving artefacts represent a smaller portion of the original "assemblage" and even securely datable "earlier" or "later" artefacts are missing. Therefore, the period spanned by the accumulation of the hoard and the dating of this "find" proposed here is no more than a reconstruction based on the typological features of the preserved specimens.

Looking at the chronological position of the closest parallels of the conical helmet, the Pustimerr type knife and the flange-hilted sword, we may say that most of the artefacts can be assigned to the Ha A period and that later (Ha B1) parallels are sporadic. ${ }^{90}$ The dating of the Fuchsstadt type cup is interesting because it was defined as hallmark of the Ha A2 period by H. Müller-Karpe, even though he did emphasize that this type also occurs in the Ha B1 period, which correlates with the dating of the pieces from the Carpathian Basin. ${ }^{91}$ Due to the lack of securely datable objects, the Pergine find was dated to the Ha B1 period on stylistic ground. ${ }^{92}$ However, other parallels of the greaves in question were deposited in Ha A hoards.

In conclusion, most of the closest parallels of the analyzed objects can be linked to the Ha A

89 We cannot exclude the possibility that they had perhaps been part of a metal armour in view of the comparably thick armour fragments known from the archaeological record (e.g. Čierna nad Tisou, Farkasgyepú-Pöröserdő). However, further conclusions cannot be drawn owing to their uncharacteristic form. PAULíK 1968, 42; JANKOVITS 1992, 37.

90 SNOdgrass 1967, 25-26; PERONI 1970, 68; BORCHHARDT 1972, 126; Ř́íHOVSKÝ 1972, 32-33; VINSKI-GASPARINI 1973, 211 ; Mozsolics 1985, 24-25, Taf. 277; KILIAN-DirLmeIER 1993, 100; ILON 2002, 161; CLAUSING 2003b, 217-218; MÖRTZ 2011, 357; VELIAČIK 2012, 279-299; MÖDLINGER 2013, 400-401; MÖDLINGER et al. 2013, 22.

91 MÜller-Karpe 1959a, 158-159; Thrane 1975, 137; Patay 1990, 57-58; PRÜSSING 1991, 23-24; HANSEN 1994, 116; JАСOB 1995, 31; HANSEN 1996, 438; SOROCEANU 2008, 50.

92 Fogolari 1943, 80-81; MARZATICO 2000, 402; Merhart 1958, 102-105; 115-117, 132; MÜLLER-KARPE 1959a, 64, 161, 197-198, 200-204; JOCKENHÖVEL 1974, 83-84; SCHAUER 1982, 134-137; JANKOVITS 1997, 14; ClAUSING 2003a, 154-158. 
period, however, later depositions have also been reported. Consequently, based on the presently known composition of the "assemblage", it can be concluded that the objects can be dated between the Ha A and Ha B1 periods, and that they were probably deposited during the latter (Fig. 13).

\section{The possible find spot}

Determining the original spot of the "assemblage" is a bold attempt considering that most of the objects are supra-regional types. The closest parallels of the flange-hilted sword come from Southern Europe, Italy and the Aegean (Fig. 1). Conical helmets are known from the Aegean and Northern Europe, but their main concentration can be noted in the Carpathian Basin (Fig. 5). The same holds true for Puštiměr type knives, although they are known from beyond this area (Fig. 10). The closest parallels of the greaves were unearthed in Italy; however the type is distributed from France to the Carpathian Basin (Fig. 7).

Fuchsstadt type cups have the most interesting distribution, appearing across roughly the entire territory of West Central Europe (Fig. 12). Even though almost all of the analyzed objects have parallels from the Carpathian Basin, it would be difficult to prove that the "assemblage" was unearthed on the territory of Hungary. However, if this was indeed the case, the probable find spot could be in southern Transdanubia or the Bakony region where hoards and burials have a similar composition..$^{93}$ Another possibility is that the objects originated from the Northern Balkans, Italy or Slovenia.

\section{The results of the macroscopic examination and the X-ray analysis}

Probably one of the most remarkable results of the macroscopic observations was the examination of the recent breakage surfaces, which was made possible by the unrestored state of the finds (e.g. Fig. 2.6-9, Fig. 11.2). With the aid of these features we were able to reconstruct the probable original state of the objects, which showed a completely different picture than we first might expect when analyzing an assemblage

\footnotetext{
93 Mozsolics 1985, 24-27; Köszegi 1988, 40-41; JANKOVITS 1992; KossaCK 1995, 44-50; ILON 2014, 113, 115; Petres-JanKOvits 2014,67 .
}

that has undergone conservation and restoration. As a result of this examination, we may conclude that almost all of the artefacts had been intact at the time of their deposition, with deliberate pre-depositional fragmentation only documented in the case of one knife (Cat. no. 7; Fig. 18.7).

Another results of the macroscopic examination was the identification of manufacturing- and probably usage-related traces. However, it should be emphasized that our current examination was constrained by the unrestored state of the artefacts. In the case of the greaves, for example, incised "guiding" lines with a width of $0.0582 \mathrm{~mm}$ were detected on the reverse, which aided the craftsman to creating symmetric patterns (Fig. 9.5-6). The undoubtedly most interesting observations were made in connection with the sword. According to both the macroscopical and the X-ray analyses, the inner structure of this weapon was porous (Fig. 2.6-7, Fig. 3). ${ }^{94}$ Despite this crucial casting fault, the sharpening of the blade, the abrasion of the rivet holes and even a small notch were detected (Fig. 2.1-2, 3-5).

Other important result was the documentation of heat damage and other destructive prehistoric manipulations, which also support the unity of this "assemblage". The lower third of the sword was not just simply bent but was practically molten by fire (Fig. 2.3-4, Fig. 4.3). Likewise, the heat damage and bending concentrated on the functional parts of the other objects. The blade of one knife (Cat. no. 6) was bent at ninety degrees and the tip of its blade was melted (Fig. 11.1), while another one (Cat. no. 8) was also almost entirely molten (Fig. 11.3). The same heat damage could be observed on the enigmatic object interpreted as a possible wagon part (Cat. no. 18) and on certain parts of the greaves (Fig. 9.3, Fig. 17.18). The greatest damage, however, was suffered by the helmet, which was wholly crumpled (Fig. 6).

\section{A "warrior" equipment?}

From a technological point of view, most of the objects can be interpreted as high quality products in view of their manufacturing techniques, which, on the testimony of experiments ${ }^{95}$ and technological studies, ${ }^{96}$ called for the complex

94 Molloy 2011, 69.

95 PiETZSCH 1968; SiedLACZEK 2011, 111-117.

96 JOCKENHÖVEL 1982, 462-467; ARMBRUSTER 2000, 98-102, 108, 111-117; FALKENSTEIN 2006-2007, 40; MÖDLINGER et al. 2013, 32-34; MÖDLINGER et al. 2014, 797-798. 
knowledge and toolset of a specialist. ${ }^{97}$ Moreover, the distribution of their closest parallels reveal clear interregional patterns which were often associated with the elite groups of Late Bronze Age societies who had exclusive access to these valuable artefacts through their supra-regional connections. ${ }^{98}$ No wonder, then that besides their utilitarian function, the theoretical research often stresses the symbolic aspects of these objects and their role in social display. ${ }^{99}$ It seems that the analyzed sword illustrates the above point well. Despite its dysfunctional blade it was sharpened, hafted and kept in a precious sheath. ${ }^{100}$

The "assemblage" was originally either a hoard or a grave assemblage; whichever the case, its composition is quite remarkable. Comparable sets of artefacts ${ }^{101}$ can be associated with the socalled "warrior graves" (e.g. Kallithea A, Portes $3^{102}$ ), ostentatious elite burials (e.g. Čaka ${ }^{103}$ ) and hoards (e.g. Nadap, ${ }^{104}$ Pázmándfalu, ${ }^{105}$ Rinyaszentkirály ${ }^{106}$ ), which appeared during the Br DHa A1 period, probably as a result of profound social changes. ${ }^{107}$ Their ideology - the expression of "masculine values" and the idealized life-style of warriors through special objects - virtually follow the same concept as Iberian stele art. ${ }^{108}$ In the case of the Carpathian Basin, one useful exercise would be an examination of the combination of these idealized sets - e.g. accessories, weapons, feasting, mobility - among the hoards. Their typological and technological traits, especially in relation to their manipulation traces, could provide additional insights into this phenomenon.

Yet, the most curious aspect of this "assemblage" is the concentration of different types of damage traces (bending, crushing, melting,

97 Armbruster 2000, 34-64; Kuijpers 2008, 54-58; Nessel 2009, 54-55, Taf. 1-2; NeSSEL 2010, 2-10.

98 KRISTIANSEN 1999, 184-185; VÁCZI 2014, 279-280, 7-8. kép.

99 KRISTIANSEN 1984, 187-189, 203-204; SPERBER 1992, 68-69, 71-74; OSGOOD 1998, 79-80; DOLFINI 2004, 283-284; SOROCEANU 2011, 45-99.

100 Swords of inferior quality were often manufactured with the purpose of displaying their owner's social status. For instance, during the Edo period in Japan (1603-1868 AD) the rare swords of Masamue were treasured so high that even fakes were manufactured and presented as gifts to the samurai class by the authorities. YOSHIMURA 2006, 116.

101 BRÜCK-FONTIJN 2013, 205-206.

102 Giannopoulos 2008, Tab. 3.

103 TOČIK-PAulík 1960; PAUlík 1963.

104 PeTRES 1990, 87-93; MAKKAY 2006, 139-145.

105 V. SZABÓ 2013, 811, Fig. 17.

106 Mozsolics 1985, 182-183, Taf. 96-98.

107 OsGOOD 1998, 77.

108 TREHERNE 1995; JOCKENHÖVEL 1971, 245-249; WEBER 1996, 261-264; HÄNSEL 1997, 83, Abb. 1; KRISTIANSEN 1999, 180-181; HARRISON 2004, 52-59; HARDING 2008, 192-194; KALlaRACZKY-V. SZABÓ 2013, 24-27, 6. kép. breakage) on the functional parts of the objects. As a result of these pre-conceived, deliberate destructions, the damage to these valuable objects was irreversible and they become completely useless after their deposition. Although the destruction of an object could be motivated by many different considerations, ${ }^{109}$ in this case, all observations support some sort of symbolic act, ${ }^{110}$ an attempt to wreck these objects before their prehistoric life-cycle ended. ${ }^{111}$ In this context, the role of fire can also be interpreted as a medium of transformation ${ }^{112}$ not merely as an effective tool of destruction. It is also curious that similar fire-damaged weapons are rare in the Carpathian Basin. Only few parallels are known, mostly from burials: e.g. Farkasgyepú-Pöröserdó II, ${ }^{113}$ Csögle, ${ }^{114}$ Szeged-Kiskundorozsma, ${ }^{115}$ Tatabánya-Bánhida, ${ }^{116}$ and Škocjan-Mušja jama. ${ }^{117}$ Beyond this region, artefacts damaged by fire have been frequently reported from "warrior graves" of Western Europe ${ }^{118}$ and the votive hoards of Italy (e.g. Pila del Brancon ${ }^{119}$ ). One intriguing assemblage still unpublished, ${ }^{120}$ comes from Tatabánya-Bánhida: its composition (e.g. two sword fragments, a cauldron rim and a possible situla fragment) and its manipulation traces also correspond to the assemblage analyzed here. It seems to me that the detailed personal examination of similar assemblages would be an essential task of future research.

In sum, the results of our evaluation suggest, that the analyzed objects can be interpreted as the remnants of a valuable, probably elite-related set, which could have been buried in a damaged condition as grave goods or a hoard in East Central Europe, most likely in the Ha B1 period.

\section{CATALOGUE ${ }^{121}$}

1. Flange-hilted sword: Allerona type hilted sword, in five pieces. The breakage surfaces of the sword are recent. Its shoulders are narrow and the tang is slightly elongat-

\footnotetext{
109 Nebelsick 1997, 40-41; NebelSick 2000, 167-171; ReZi 2011, 303-307; MÖRTZ 2013, 58-59.

110 Nebelsick 1997, 40; JanKovits 1999-2000, 202.

111 KopytofF 1986, 65-67; Fontijn 2002, 247-258, Fig. 13.1.

112 Nebelsick 2000, 167; SZEVERÉNYI 2013, 222-224, 227.

113 JANKOVITS 1992, 37, Abb. 28.2.

114 KemenCZei 1988, 46, Taf. 19.196

115 KemenCZei 1991, 85, Taf. 70.442.

116 Mozsolics 1985, 94; KeMENCZEI 1991, 85, Taf. 70.446-447.

117 HARDING 1995, 48, Taf. 42.390-392, 400-401.

118 Clausing 2005, 103-106.

119 JANKOVITS 1999-2000, 202; BietTi SESTIERI et al. 2013, 159-163.

120 Mozsolics 1985, 94; KemenCZeI 1991, 85.

121 Abbreviations: 1.: length, w.: width, h.: height, d.: diameter, th.: thickness, w2.: weight, o.l.: outstretched length.
} 


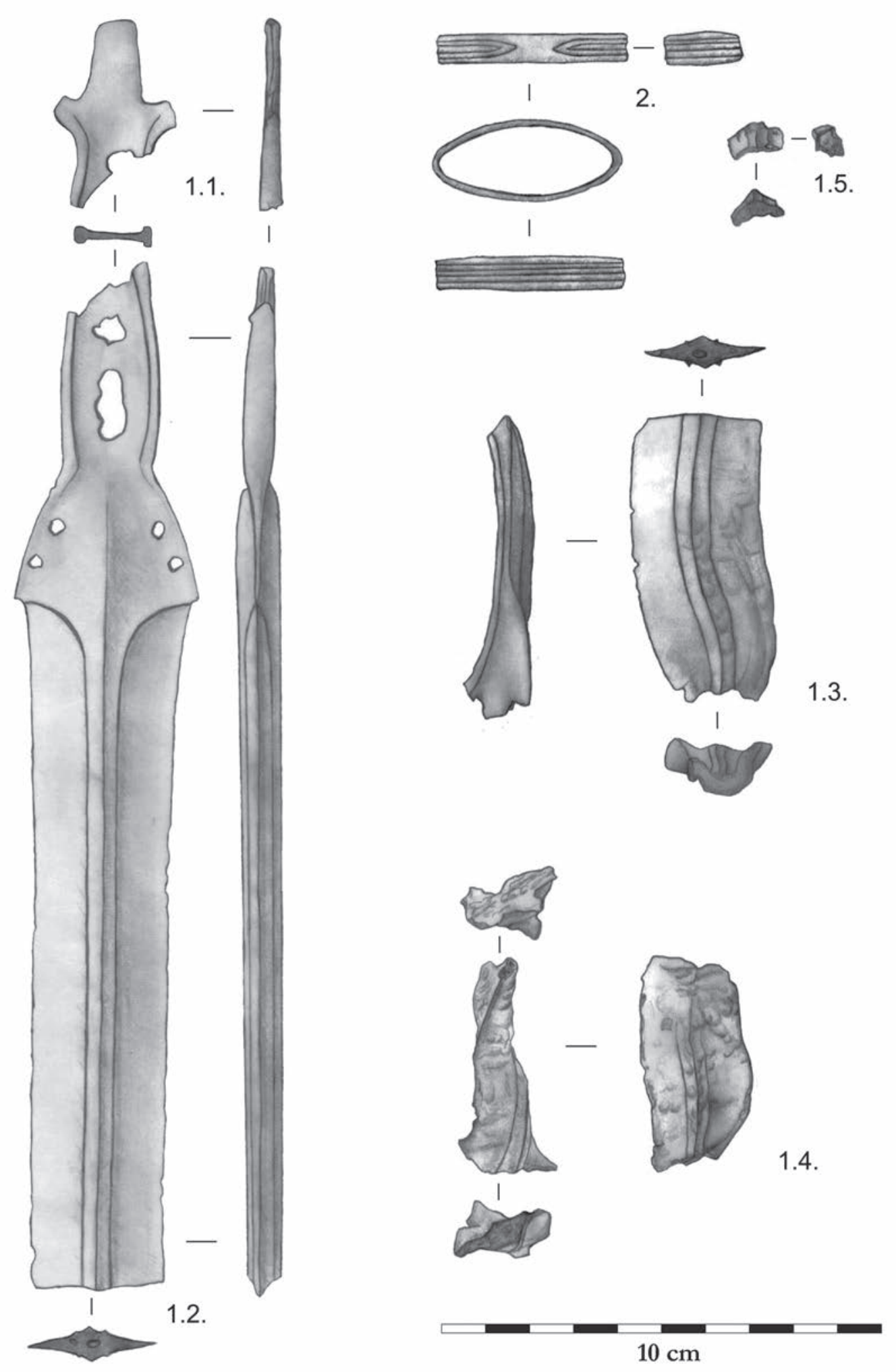

Fig. 14. 1: Fragments of the flange-hilted sword with extended tang; 2: sheath part 14. kép. 1: A hosszított markolatú, nyélnyújtványos kard töredékei; 2: hüvelyszerelék 
ed with prominent flanges. The tang characteristically ends in a tongue-shaped projection and has two projecting ears. Four rivet holes are visible along the tang, and four near the shoulders. The transition between the hilt plate and the blade is slightly concave. The rhomboid-sectioned blade has a midrib down its centre. The blade is bent by fire and its lower sections are intensively melted, with some pieces detached from the main body. The surface of this zone is intensively blistered and fragments 1.3, 1.4 and 1.5 are deformed. Due to the unrestored state, it was difficult to perform a macroscopic examination; however, traces of sharpening could be noted $7.7 \mathrm{~cm}$ from the transition. A small notch was detected on the other side of the blade, although this could also be a result of recent damage. The breakage surfaces were porous. The breakage of fragments 1.2 and 1.3 occurred along this porous part. Overall dimensions: 1. (outstretched length): $45.3 \mathrm{~cm}, 1$. (extension): $1.1 \mathrm{~cm}, 1.6$ $\mathrm{cm}, \mathrm{w}$. (under the extension): $2 \mathrm{~cm}, \mathrm{w}$. (middle of the hilt): $2.5 \mathrm{~cm}$, w. (above the hilt): $2.4 \mathrm{~cm}, \mathrm{w}$. (shoulders): $4.9 \mathrm{~cm}$, w. (interface): $4.4 \mathrm{~cm}, \mathrm{w}$. (middle of the blade): $3.5 \mathrm{~cm}$, th. (tang): $0.8 \mathrm{~cm}, 0.2 \mathrm{~cm}$, th. (blade): $0.8 \mathrm{~cm}, \mathrm{w} 2 .: 436 \mathrm{~g}$. 1. 1) $5.1 \mathrm{~cm} \times 3.2 \mathrm{~cm}$, th.: $0.5 \mathrm{~cm}$, w2.: $16 \mathrm{~g}$ (Fig. 14.1.1). 1. 2) 1.: $27.2 \mathrm{~cm}$, w. (middle of the hilt): $2.5 \mathrm{~cm}$, w. (above the hilt): $2.4 \mathrm{~cm}$, w. (shoulders): $4.9 \mathrm{~cm}, \mathrm{w}$. (interface): $4.4 \mathrm{~cm}$, th.: $0.9 \mathrm{~cm}$, w2: $282 \mathrm{~g}$ (Fig. 14.1.2). 1.3) $1 .: 8 \mathrm{~cm}$. w.: $3.6 \mathrm{~cm}$, th.: $0.9 \mathrm{~cm}$, w2.: $84 \mathrm{~g}$ (Fig. 14.1.3). 1. 4) $1 .: 5.9 \mathrm{~cm}$, th.: $0.8 \mathrm{~cm}$, w2.: $48 \mathrm{~g}$ (Fig. 14.1.4). 1. 5) 1.: $1.4 \mathrm{~cm}$, th.: $0.9 \mathrm{~cm}$, w2.: $6 \mathrm{~g}$. (Fig. 14.1.5)

2. Mount of the sheath: Oval, square-sectioned, sheet metal object. Its exterior is decorated with bundles of lines and antithetic curved patterns. $1 .: 5 \mathrm{~cm}, \mathrm{w} .: 0.6 \mathrm{~cm}$, th.: $0.1 \mathrm{~cm}$, w2.: $10 \mathrm{~g}$ (Fig. 14.2).

3. Helmet: Conical helmet with cast knob, in four pieces. The breakage surfaces of the fragments are recent. There is a small hole in the centre of the knob. The body is undecorated and thickens towards the edge. The rivet holes along the edge, where hammering traces are also visible, were punched inward from the exterior. The original state of the helmet may have been more intact prior to the crumpling before its deposition (e.g. Cat. no. 3.2). 3. 1) h.: $2.7 \mathrm{~cm}, \mathrm{w}$. (upper part of the knob): $2.5 \mathrm{~cm}, \mathrm{w}$. (neck of the knob): $1.7 \mathrm{~cm}$, w (bottom of the knob): $2.7 \mathrm{~cm}$, d. (of the rivet head): $2 \mathrm{~cm}, \mathrm{w} 2 .: 40 \mathrm{~g}$ (Fig. 15.3.1). 3. 2) 1.: $13.2 \mathrm{~cm}, \mathrm{w} .: 4.3 \mathrm{~cm}, 6.2 \mathrm{~cm}, 6.1 \mathrm{~cm}$, th. (of rim): $0.2 \mathrm{~cm}$, th. (of the upper part): $0.01 \mathrm{~cm}, \mathrm{w} 2 .: 90 \mathrm{~g}$ (Fig. 15.3.2). 3. 3) 1.: $7.9 \mathrm{~cm}$, w.: $3.6 \mathrm{~cm}$, th.: $0.1 \mathrm{~cm}, \mathrm{w} 2 .: 24 \mathrm{~g}$ (Fig. 15.3.3). 3. $4.1 .: 4.8 \mathrm{~cm}$, w.: $1.9 \mathrm{~cm}$, th.: $0.2 \mathrm{~cm}$, w2.: $11 \mathrm{~g}$ (Fig. 15.3.4).

4. Greave (no. 1): The greave consist of twelve smaller fragments whose breakage surfaces are recent in every case. The shape of the object is ovaloid and has a metal wire lace under the rim. The repoussé patterns were made by punching from the reverse. The motifs are almost identical to the ones on the Pergine greaves. The front part is divided by bundles of vertical lines and a horizontal one in the upper section. The main decorative design is composed of "anthropomorphic" and "zoomorphic" motifs that are separated from each other by concentric circles. Lightly incised lines (width: $0.0582 \mathrm{~mm}$ ) can be made out on the reverse. These "guiding" lines aided the craftsman in creating symmetric patterns. Overall dimensions: $27.3 \mathrm{~cm}$, w.: $17.1 \mathrm{~cm}, \mathrm{w} 2 .: 192$ g. 4. 1) $8.2 \mathrm{~cm} \times 5.6 \mathrm{~cm}$, th.: $0.1 \mathrm{~cm}$, w2.: $17 \mathrm{~g}$ (Fig. 16.4.1). 4. 2) 7.6 $\mathrm{cm} \times 6.8 \mathrm{~cm}$, th.: $0.1 \mathrm{~cm}$, w2.: $16 \mathrm{~g}$ (Fig. 16.4.2). 4. 3) $6 \mathrm{~cm} \times 4.2 \mathrm{~cm}$, th.: $0.1 \mathrm{~cm}$, w2.: $9 \mathrm{~g}$ (Fig. 16.4.3). 4. 4) 1.8 $\mathrm{cm} \times 1.1 \mathrm{~cm}$, th.: $0.1 \mathrm{~cm}$, w2.: $2 \mathrm{~g}$ (Fig. 16.4.4). 4. 5) 1.9 $\mathrm{cm} \times 1.7 \mathrm{~cm}$, th.: $0.1 \mathrm{~cm}$, w2.: $1 \mathrm{~g}$ (Fig. 16.4.5). 4. 6) $3.7 \mathrm{~cm} \times$ $3 \mathrm{~cm}$, th.: $0.1 \mathrm{~cm}$, w2.: $4 \mathrm{~g}$ (Fig. 16.4.6). 4. 7) $8.2 \mathrm{~cm} \times 8.8 \mathrm{~cm}$, th.: $0.1 \mathrm{~cm}$, w2.: $32 \mathrm{~g}$ (Fig. 16.4.7). 4. 8) $6.1 \mathrm{~cm} \times 2 \mathrm{~cm}$, th.: $0.1 \mathrm{~cm}$, w2.: $6 \mathrm{~g}$ (Fig. 16.4.8). 4. 9) $19 \mathrm{~cm} \times 7.2 \mathrm{~cm}$, th.: 0.1 cm, w2.: $59 \mathrm{~g}$ (Fig. 16.4.9). 4. 10) $7.2 \mathrm{~cm} \times 3.6 \mathrm{~cm}$, th.: $0.1 \mathrm{~cm}$, w2.: $12 \mathrm{~g}$ (Fig. 16.4.10). 4. 11) $12 \mathrm{~cm} \times 6.8 \mathrm{~cm}$, th.: $0.1 \mathrm{~cm}$, w2.: $28 \mathrm{~g}$ (Fig. 16.4.11). 4. 12) $3.5 \mathrm{~cm} \times 2 \mathrm{~cm}$, th.: $0.1 \mathrm{~cm}$, w2.: $6 \mathrm{~g}$ (Fig. 16.4.12).

5.1-4. Greave (no. 2): Larger fragment of a greave with remains of the central repoussé decoration punched from the reverse. The design is composed of bundles of vertical lines and "anthropomorphic" and "zoomorphic" motifs. The breakage surfaces are recent. $10.1 \mathrm{~cm}$, th.: 0.1 cm, w2.: 15.5 g. 5.1 ) $6 \mathrm{~cm} \times 4.1 \mathrm{~cm}$, th.: $0.1 \mathrm{~cm}$, w2.: $8 \mathrm{~g}$ (Fig. 17.5.1). 5. 2) $4.5 \mathrm{~cm} \times 2.2 \mathrm{~cm}$, th.: $0.1 \mathrm{~cm}, \mathrm{w} 2 .: 6 \mathrm{~g}$ (Fig. 17.5.2). 5. 3) $1.1 \mathrm{~cm} \times 0.9 \mathrm{~cm}$, th.: $0.1 \mathrm{~cm}$, w2.: $1 \mathrm{~g}$ (Fig. 17.5.3). 5. 4) $2.1 \mathrm{~cm} \times 1.2 \mathrm{~cm}$, th.: $0.1 \mathrm{~cm}$, w2.: $0.5 \mathrm{~g}$ (Fig. 17.5.4).

5.5-8. Greave (no. 2): Larger fragment of the greave described under Cat. no. 5.1-4, in five pieces. The fragments are decorated with fine repoussé patterns. Based on the forms of the patterns, these fragments could be indentified as the central part of the object. The breakage surfaces are recent. 5.5$) 2.6 \mathrm{~cm} \times 2.5 \mathrm{~cm}$, th.: $0.1 \mathrm{~cm}$, w2.: $3 \mathrm{~g}$ (Fig. 17.5.5). 5.6) $2.9 \mathrm{~cm} \times 1.2 \mathrm{~cm}$, th.: $0.1 \mathrm{~cm}$, w2.: $1 \mathrm{~g}$ (Fig. 17.5.6). 5.7) $2.3 \mathrm{~cm} \times 1.5 \mathrm{~cm}$, th.: $0.1 \mathrm{~cm}, \mathrm{w} 2 .: 1 \mathrm{~g}$ (Fig. 17.5.7). 5.8) $1.4 \mathrm{~cm} \times 0.7 \mathrm{~cm}$, th.: $0.1 \mathrm{~cm}$, w2.: $0.5 \mathrm{~g}$ (Fig. 17.5.8).

5.9-12. Greaves fragment (no. 2): Lower fragment of the greaves described under Cat. no. 5.1-5.4, in four pieces (5.9-5.12). The traces of the repoussé motifs punched from the reverse are hard to identify due to intensive heat damage. Only traces of the bundles of vertical lines and the "anthropomorphic" motif can be made out. 5. 9) $4.5 \mathrm{~cm} \times 3.5 \mathrm{~cm}$, th.: $0.1 \mathrm{~cm}, \mathrm{w} 2 .: 4 \mathrm{~g}$ (Fig. 17.5.9). 5. 10) $2.4 \mathrm{~cm} \times 1.4 \mathrm{~cm}$, th.: $0.1 \mathrm{~cm}$, w2.: $1 \mathrm{~g}$ (Fig. 17.5.10). 5. 11) $7.8 \mathrm{~cm} \times 4.6 \mathrm{~cm}$, th.: $0.1 \mathrm{~cm}, \mathrm{w} 2 .: 17 \mathrm{~g}$ (Fig. 17.5.11). 5. 12) $2.3 \mathrm{~cm} \times 1.4 \mathrm{~cm}$, th.: $0.1 \mathrm{~cm}, \mathrm{w} 2 .: 1 \mathrm{~g}$ (Fig. 17.5.12).

\section{$4 / 5$. Greave fragment ${ }^{122}$}

4/5/1.1-2: Edge fragment of a greave in two pieces. The breakage surfaces are recent. The repoussé decoration of the object is composed of three parallel lines along the edge and two bundles of horizontal lines. The fragment is slightly molten due to intensive heat damage. 4/5/1.1.) $2.9 \mathrm{~cm} \times 2 \mathrm{~cm}$, th.: $0.1 \mathrm{~cm}$, w2.: $5 \mathrm{~g}$ (Fig. 17.4/5.1.1). 4/5/1.2) $3.8 \mathrm{~cm} \times 2.3 \mathrm{~cm}$, th.: $0.1 \mathrm{~cm}$, w2.: $4 \mathrm{~g}$ (Fig. 17.4/5.1.2).

4/5.2. Greave fragment: Edge fragment of a greave with repoussé decoration and the remains of the metal

\footnotetext{
122 Fragments which could not be paired with certainty with the greaves described under Cat. no. 4 and 5 were assigned to this group (No. 4/5).
} 


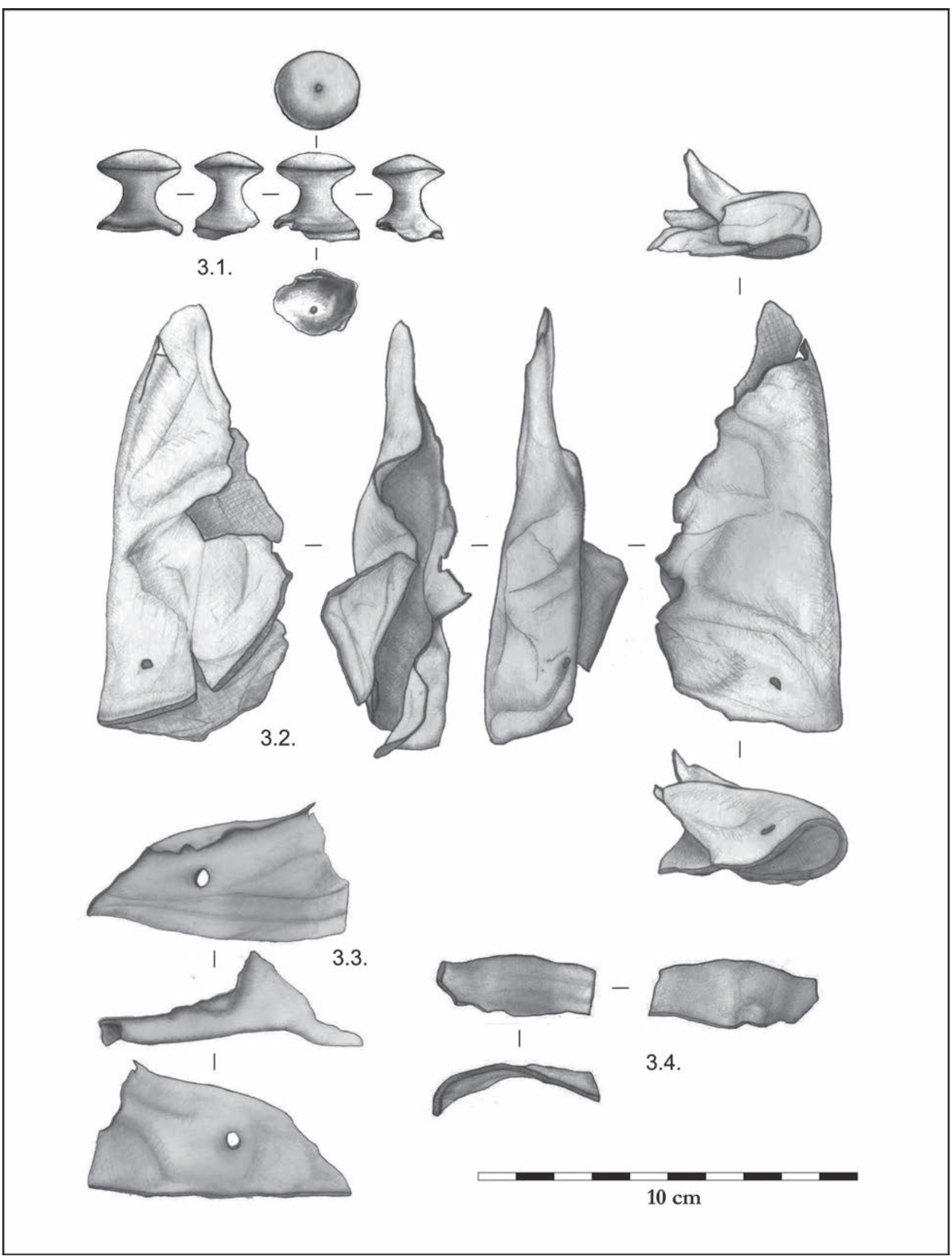

Fig. 15. 3: Fragments of the conical helmet

15. kép. 3: A kónikus sisak töredékei 

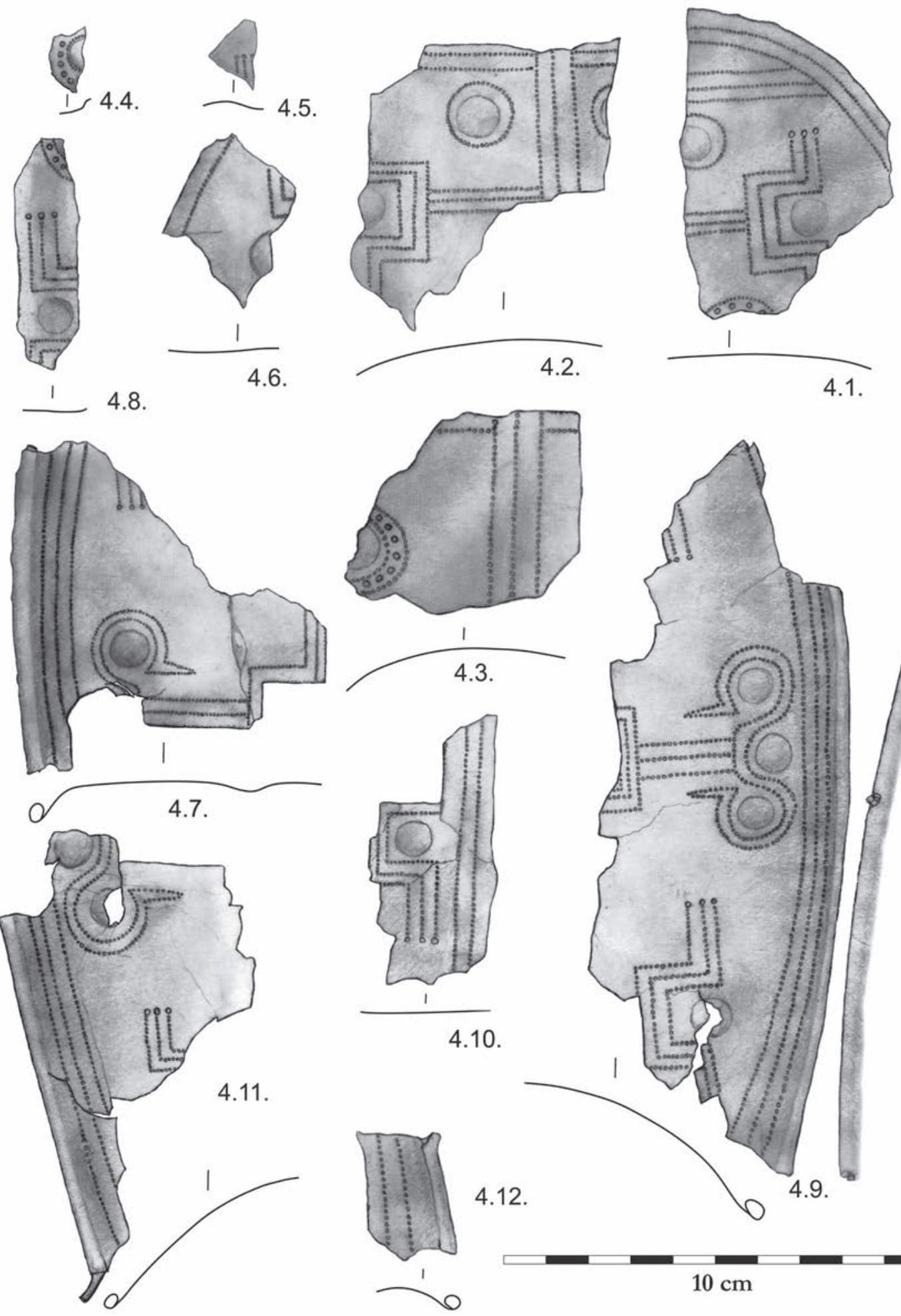

4.12.
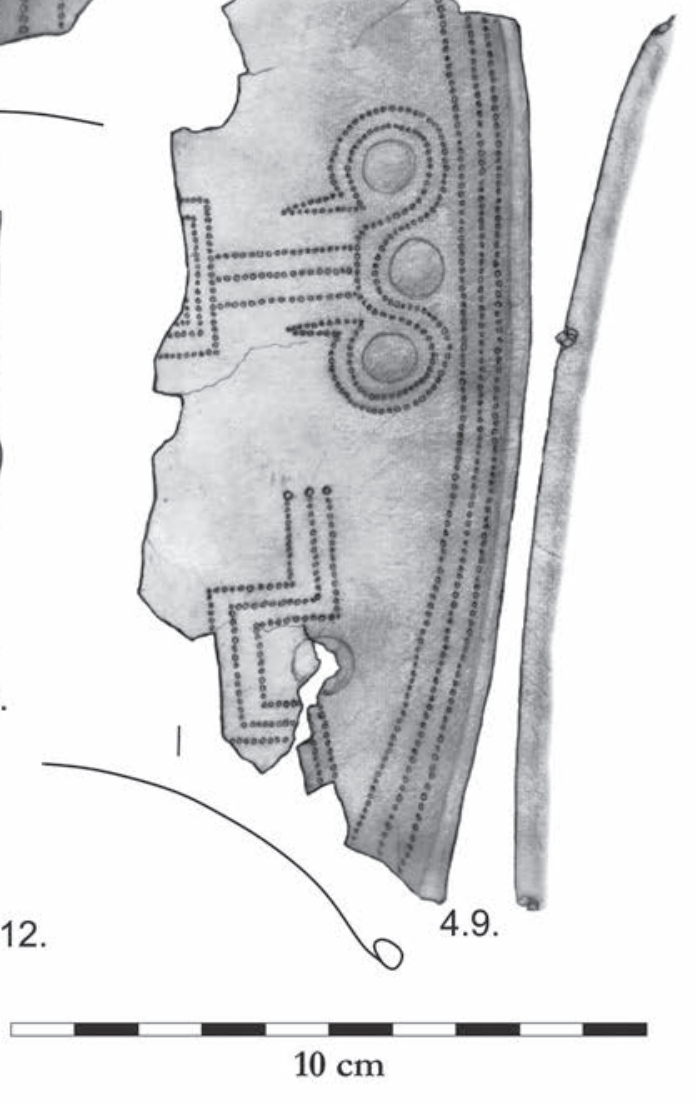

Fig. 16. 4: Greave fragments (Cat. no. 4) 16. kép. 4: A 4. lábszárvédő töredékei 

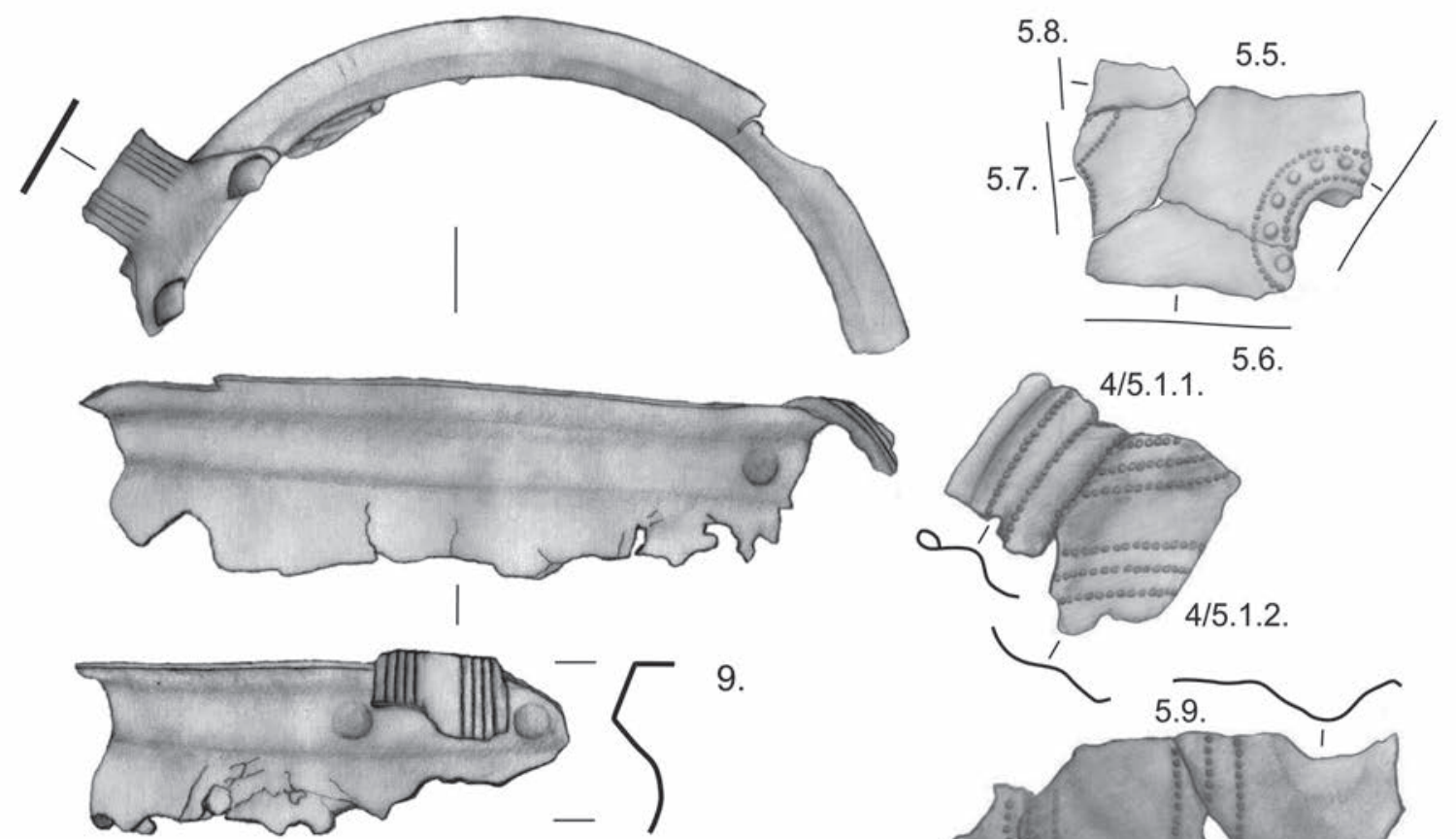

9.

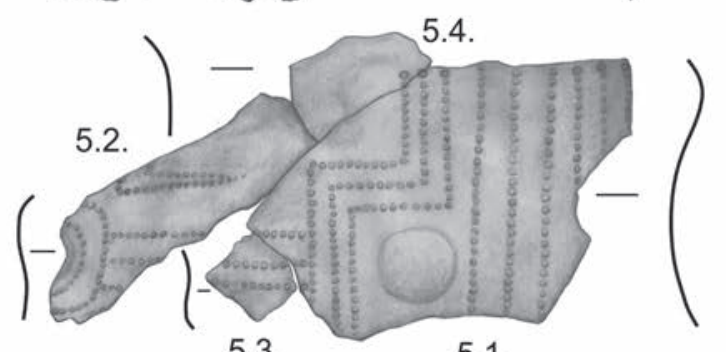

5.12 .

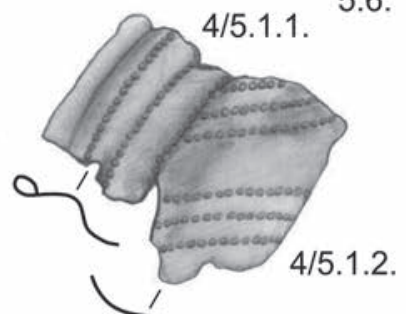

4/5.1.2.

5.3.

5.1 .
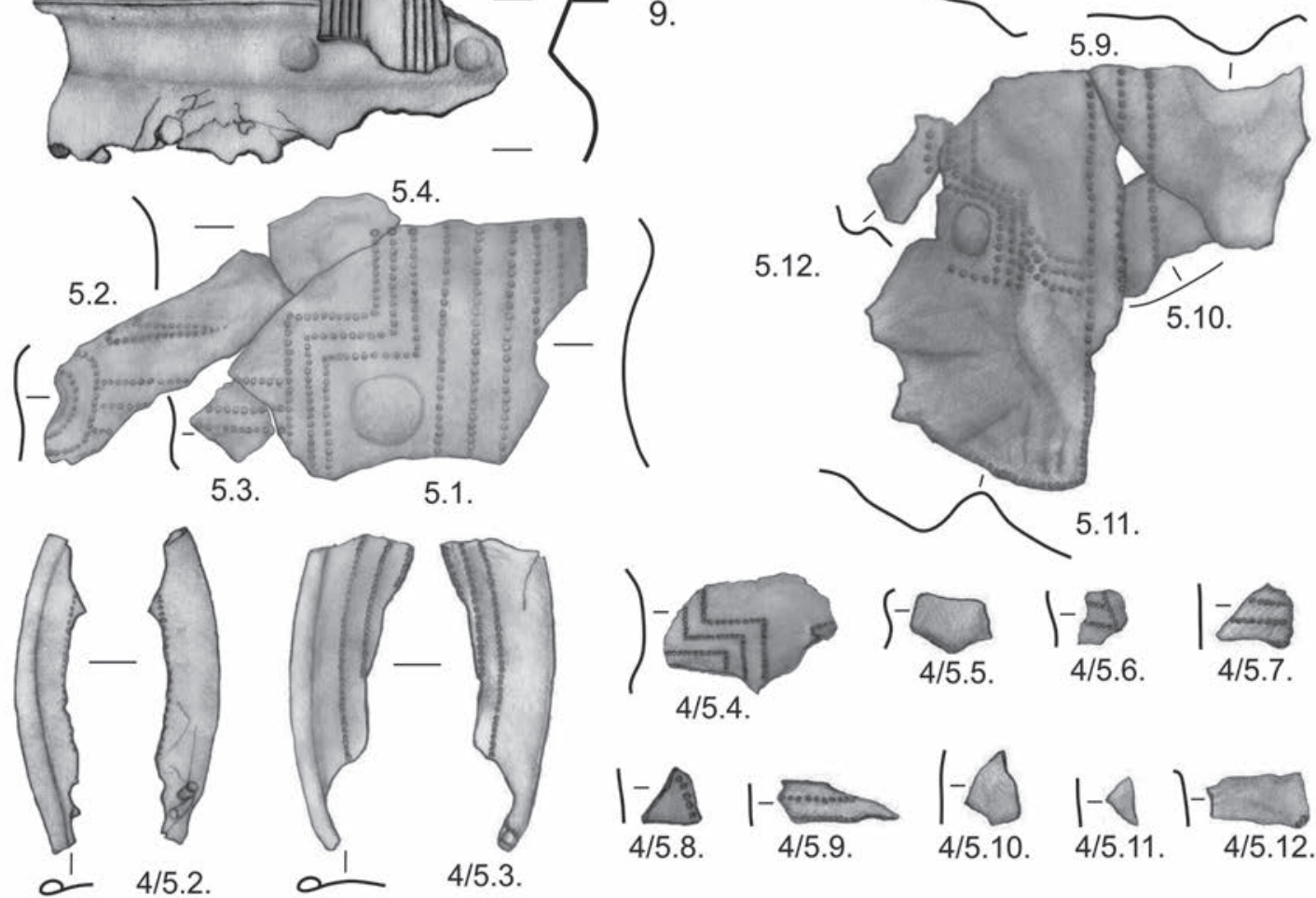

4/5.3.
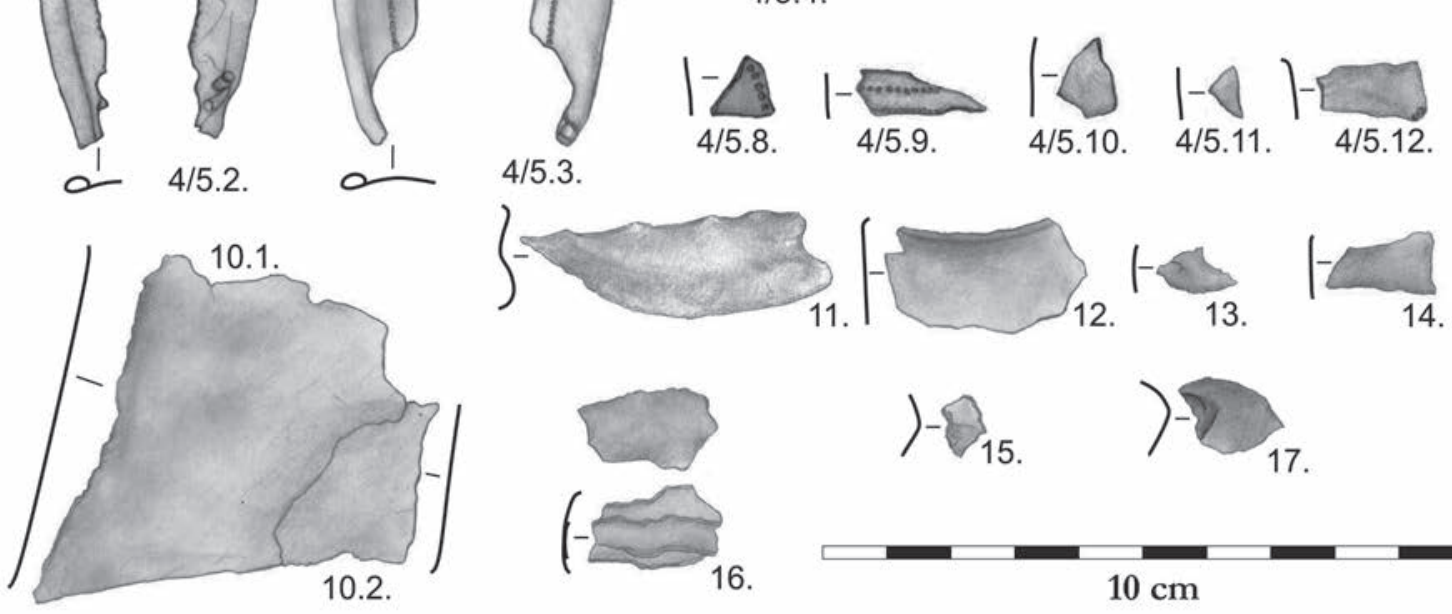

16.

Fig. 17. 5: Greave fragments (Cat. no. 5); 4/5: greave fragments; 9: Fuchsstadt type cup; 10-17: unclassifiable metal sheet fragments

17. kép. 5: Az 5. lábszárvédő töredékei; 4/5: lábszárvédő-töredékek; 9: Fuchsstadt-típusú csésze; 10-17: klasszifikálhatatlan fémlemez-töredékek 
wire lace. The breakage surfaces are recent. $6.4 \mathrm{~cm} \times 1.6$ $\mathrm{cm}$, th.: $0.1 \mathrm{~cm}$, w2.: $7 \mathrm{~g}$ (Fig. 17.4/5.2).

4/5.3. Greave fragment: Edge fragment of a greave with repousse decoration and the remains of the metal wire lace. The breakage surfaces are recent. $6.2 \mathrm{~cm} \times 2.1$ $\mathrm{cm}$, th.: $0.1 \mathrm{~cm}$, w2.: $7 \mathrm{~g}$ (Fig. 17.4/5.3).

4/5.4. Greave fragment: Small fragment of a greave with a geometric repoussé design (probably part of the central motif). The breakage surfaces are recent. 3.3 $\mathrm{cm} \times 2.2 \mathrm{~cm}$, th.: $0.1 \mathrm{~cm}$, w2.: $6 \mathrm{~g}$ (Fig. 17.4/5.4).

4/5.5. Greave fragment: Small fragment of a greave with recent breakage surfaces. $1.6 \mathrm{~cm} \times 1.2 \mathrm{~cm}$, th.: $0.1 \mathrm{~cm}$, w2.: $1 \mathrm{~g}$ (Fig. 17.4/5.5).

4/5.6. Greave fragment: Edge fragment of a greave. Its decoration is composed of fine repoussé lines. The breakage surfaces are recent. $1.2 \mathrm{~cm} \times 1.1 \mathrm{~cm}$, th.: $0.1 \mathrm{~cm}$, w2.: $1 \mathrm{~g}($ Fig. 17.4/5.6).

4/5.7. Greave fragment: Small fragment of a greave with repoussé decoration. Its pattern is composed of three parallel bundles of lines. The breakage surfaces are recent. $1.6 \mathrm{~cm} \times 1.2 \mathrm{~cm}$, th.: $0.1 \mathrm{~cm}$, w2.: $1 \mathrm{~g}$ (Fig. 17.4/5.7).

4/5.8. Greave fragment: Small fragment of a greave with recent breakage surfaces. $1 \mathrm{~cm} \times 1.1 \mathrm{~cm}$, th.: $0.1 \mathrm{~cm}$, w2.: $1 \mathrm{~g}$ (Fig. 17.4/5.8).

4/5.9. Greave fragment: Small fragment of a greave with a pattern of two repoussé lines. The breakage surfaces are recent. $2.3 \mathrm{~cm} \times 0.8 \mathrm{~cm}$, th.: $0.1 \mathrm{~cm}, \mathrm{w} 2 .: 1 \mathrm{~g}$ (Fig. 17.4/5.9).

4/5.10. Greave fragment: Thin, undecorated fragment of a greave with recent breakage surfaces. $1.5 \mathrm{~cm} \times 1.2 \mathrm{~cm}$, th.: $0.1 \mathrm{~cm}$, w2.: $1 \mathrm{~g}$ (Fig. 17.4/5.10).

4/5.11. Greave fragment: Thin, undecorated fragment of a greave with recent breakage surfaces. $1 \mathrm{~cm} \times 0.8 \mathrm{~cm}$, th.: $0.1 \mathrm{~cm}$, w2.: $1 \mathrm{~g}$ (Fig. 17.4/5.11).

4/5.12. Greave fragment: Thin, undecorated fragment of a greave with recent breakage surfaces. $1.1 \mathrm{~cm} \times 1.9 \mathrm{~cm}$, th.: $0.1 \mathrm{~cm}, \mathrm{w} 2 .: 1 \mathrm{~g}$ (Fig. 17.4/5.12).

6. Flange-hilted knife: Flange-hilted knife, in two fragments (Cat. nos 6.1-2). Its blade is bent by ninety degrees, but the breakage surface is recent. The terminals of the hilt are slightly recurved. One rivet with traces of hammering is visible on the hilt. The back of the blade is slightly curved; however, it cannot be described typologically due to the intensive heat damage to this section. Both narrow sides of the hilt and the blade are decorated with complex geometric patterns. It should be noted that the complete design cannot be reconstructed due to its unrestored state. Overall dimensions: o.1.: $14 \mathrm{~cm}$, th. of the hilt: $0.2 \mathrm{~cm}$, th. of the narrow sides of the hilt: $0.7 \mathrm{~cm}$, th. of the blade: $0.6 \mathrm{~cm}$, w2.: 43 g. 6.1 .) $1 .: 6.2 \mathrm{~cm}$, w.: 1.8 cm, $1.3 \mathrm{~cm}$, w.: $0.2 \mathrm{~cm}, 0.5 \mathrm{~cm}$, w2.: $18 \mathrm{~g}$ (Fig. 18.6.1). 6. 2.) $6.8 \mathrm{~cm} \times 2 \mathrm{~cm}$, o.1.: $7.6 \mathrm{~cm}$, th.: $0.7 \mathrm{~cm}, 0.4 \mathrm{~cm}, 0.3 \mathrm{~cm}$, w2.: $25 \mathrm{~g}$ (Fig. 18.6.2).

7. Flange-hilted knife: Pustiměř type flange-hilted knife. Due to its fragmentary state, only two rivet holes are visible on its hilt. The transition between the blade and the hilt is straight, conforming to the form of the blade, which has a slight curve. Four parallel lines can be seen on the back of the blade. The tip of the blade is broken, probably as a result of prehistoric manipulation. Overall 1.: $12.1 \mathrm{~cm}$, 1. of the hilt: $3.2 \mathrm{~cm}$, 1. of the blade: 8.8 $\mathrm{cm}$, w. of the hilt: $1.3 \mathrm{~cm}$, w. of the blade: $2.3 \mathrm{~cm}, 2.5 \mathrm{~cm}$, $2.2 \mathrm{~cm}$, th. of the hilt: $0.5 \mathrm{~cm}$, th. of the back: $0.5 \mathrm{~cm}$, th. of the blade: $0.01 \mathrm{~cm}$, w2.: $39 \mathrm{~g}$ (Fig. 18.7).

8. Flange-hilted knife: Molten fragment of a flange-hilted knife. Only the transition between the blade and the hilt can be identified. $1 .: 4 \mathrm{~cm}$, w.: $1.8 \mathrm{~cm}, 0.5 \mathrm{~cm}$, $1.3 \mathrm{~cm}$, w2.: $14 \mathrm{~g}$ (Fig. 18.8).

9. Metal cup: Fragment of a Fuchsstadt type cup with straight rim. The neck is funnel-shaped, the shoulders are slightly rounded. The sheet metal handle is decorated with four lines and attached by two conical-headed rivets. All breakage surfaces are recent. $14.6 \mathrm{~cm} \times 4.7 \mathrm{~cm}$, th.: $0.1 \mathrm{~cm}, 1$. of the rim: $0.6 \mathrm{~cm}$, h. of the neck: $1 \mathrm{~cm}$, h. of the shoulders: $1.8 \mathrm{~cm}$, estimated d. of the rim: $14 \mathrm{~cm}, \mathrm{w} 2$.: $38 \mathrm{~g}$ (Fig. 17.9).

10. Metal sheet fragments: Thin, slightly curved metal sheet fragments with traces of recent breakage surfaces. 10.1.) $6.7 \mathrm{~cm} \times 4.3 \mathrm{~cm}$, th.: $0.1 \mathrm{~cm}$, w2.: $7 \mathrm{~g}$ (Fig. 17.10.1). 10.2.) $3.3 \mathrm{~cm} \times 2 \mathrm{~cm}$, th.: $0.1 \mathrm{~cm}, \mathrm{w} 2 .: 1 \mathrm{~g}$ (Fig. 17.10.2).

11. Metal sheet fragment: Slightly curved metal sheet fragment with traces of recent damage along its breakage surfaces. $5.5 \mathrm{~cm} \times 2 \mathrm{~cm}$, th.: $0.1 \mathrm{~cm}$, w2.: $4 \mathrm{~g}$ (Fig. 17.11).

12. Metal sheet fragment: Thin, undecorated metal sheet fragment. $3.5 \mathrm{~cm} \times 2.1 \mathrm{~cm}$, th.: $0.1 \mathrm{~cm}$, w2.: $2 \mathrm{~g}$ (Fig. 17.12).

13. Metal sheet fragment: Thin, undecorated metal sheet fragment. It is slightly bent. $2.3 \mathrm{~cm} \times 1.7 \mathrm{~cm}$, th.: 0.1 cm, w2.: $1 \mathrm{~g}$ (Fig. 17.13).

14. Metal sheet fragment: Thin, undecorated metal sheet fragment with traces of recent damage $1.9 \mathrm{~cm} \times$ $1 \mathrm{~cm}$, th.: $0.1 \mathrm{~cm}$, w2.: $1 \mathrm{~g}$ (Fig. 17.14).

15. Metal sheet fragment: Thin, undecorated metal sheet fragment with recent breakage surfaces. $1.1 \mathrm{~cm} \times 0.6$ cm, th.: $0.1 \mathrm{~cm}$, w2.: $0.4 \mathrm{~g}$ (Fig. 17.15).

16. Metal sheet fragment: Thick, undecorated metal sheet fragment with traces of recent damage. $2.3 \mathrm{~cm} \times 2.4$ $\mathrm{cm}$, th.: $0.1 \mathrm{~cm}$, w2.: $2 \mathrm{~g}$ (Fig. 17.16).

17. Metal sheet fragment: Thick, undecorated metal sheet fragment with recent breakage surfaces.1.8 $\mathrm{cm} \times 1.3$ $\mathrm{cm}$, th.: $0.1 \mathrm{~cm}$, w2.: $1 \mathrm{~g}$ (Fig. 17.17).

18. Unidentifiable object (perhaps a wagon model part): Tubular object with thickened rim. Four ribs with engraved decoration encircle the body and there are two rhomboid-sectioned projections on the narrow side. Its deformed state is probable the result of heat damage. 6.5 $\mathrm{cm} \times 2.1 \mathrm{~cm}$, th. of the rim.: $0.3 \mathrm{~cm}, 0.6 \mathrm{~cm}, \mathrm{w} 2 .: 81 \mathrm{~g}$ (Fig. 18.18). 


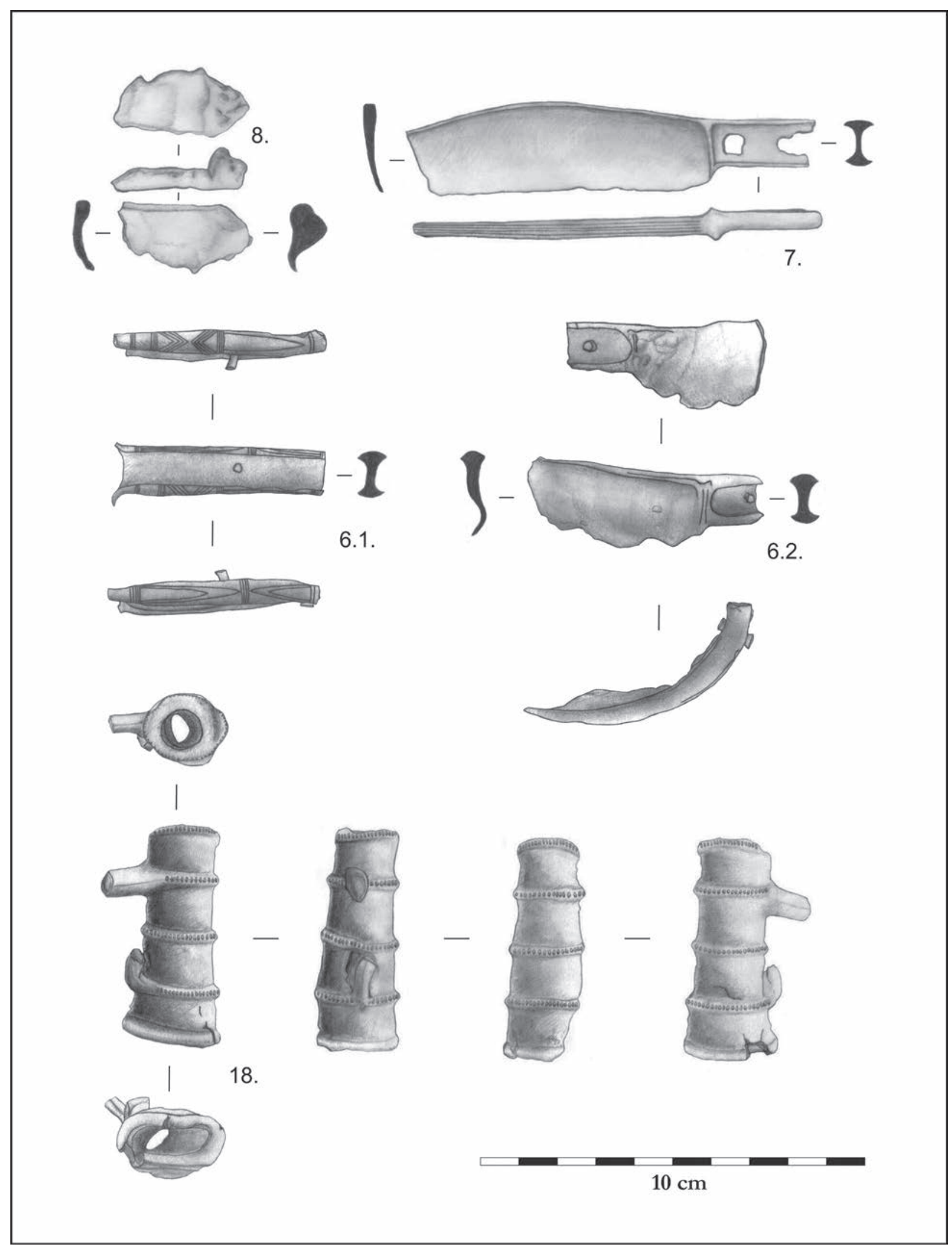

Fig. 18. 6-8: Flange-hilted knives; 18: unclassifiable object (perhaps from a wagon model) 18. kép. 6-8: Nyélnyújtványos kések; 18: azonosíthatatlan tárgy (kocsiszerelék?) 
Lists

List I. Flange-hilted swords with extended tang (Allerona type, Stätzling type, Naue IIC type, D Type) $)^{123}$

1. Allerona (Italy, Umbria), unknown, Allerona type: Colini 1900, 144, Tav. VIII.4; PERONI 1970, 66, Taf. 21.153.

2. Antheia/Clauss (Greece, Achaea), grave, Stätzling type: PAPAdOPOUlos 1984, 221-223, Fig. 2.

3. "Apulia" (Italy, Apulia), private collection, Allerona type: NAue 1896, 96, Tav. III.3; PERONI 1970, 66, Taf. 22.157.

4. Barç (Albania, Korçe), Mound 2/Grave 146.II, Naue IIC type: Andrea 1985, 42, Tab. XIV; Kilian-DirlmeIER 1993, 98, Taf. 38.253.

5. Berlin-Spandau (Germany, Berlin), hoard, Stätzling type: SPROCKHOFF 1931, 96, Taf. 6.2; SCHAUER 1971, 145.

6. Bevensen (Germany, Lower Saxony), grave, Stätzling type: SPROCKHOFF 1931, 95, Taf. 8.18.

7. Bodrog (Slovakia, Trebišov), hoard, Stätzling type: NovotNÁ 1970, 91, Taf. XIX.

8. Boeslunde (Denmark, Sjælland), unknown context, "sword with extended tang": SPROCKHOFF 1931, Taf. 18.6.

9. Budapest-Margit-sziget (Hungary, Pest), river find, D type: JósA 1893, 268, 3. t. 6; KeMENCZEI 1988, Taf. 39.353.

10. Bregenz (Austria, Vorarlberg), river find, Stätzling type: SCHAUER 1971, 144, Taf. 63.433.

11. Campodenno (Italy, Trentino), stray find, Allerona type: PERONI 1970, 69, Taf. 23.161.

12. Casale sul Sile (Italy, Veneto), river find, Allerona type: PERONI 1970, 66, Tav. 22.154.

13. Donji Petrovci (Serbia, Vojvodina), hoard, Stätzling type: HARDING 1995, 50, Taf. 21.175.

14. Enkomi (Greece, Ciprus) Grave 47/1890, Naue IIC type: MATTHÄUs 1985, 364, Taf. 140.2.

15. Fucino, vicinanze (Italy, L'Aquila, Abruzzi), grave, Allerona type: Bullettino Di PALETNOLOGIA ItALIANA 1886, 261; PERONI 1970, 68, Taf. 22.158.

16. Fucino (Italy, L'Aquila, Abruzzi), unknown context, Allerona type: Bullettino di Paletnologia Italiana 1886, 261; PERONI 1970, 68, Taf. 23.159.

17. Graditsa (Greece), private collection, Naue IIC type: CATLing 1961, 11, Pl. 16.c, Pl. 17.b; KILIAN-DiRLMeIER 1993, 97, Taf. 37.245-246.

18. Hajdúböszörmény (Hungary, Hajdú-Bihar), stray find, D type: HAMPEL 1892, CLVII, 1.a-b; KEMENCZEI 1988, Taf. 39.354.

19. Hódmezóvásárhely-Batida (Hungary, Csongrád), grave, D type: BANNER 1944-1945, Taf. 11.1; KeMENCZEI 1988, 66, Taf. 39.355.

20. Hungary, unknown, D type: SzÁRAZ 1891, 325, III. t. 7; KemenCZEI 1988, 66, Taf. 40.360.

21. Hungary, unknown, D type: Kemenczei 1988, 66, Taf. 40.361 .

22. Hungary, unknown, D type: HAMPEL 1886, XX. t. 8; Kemenczei 1988, 66, Taf. 38.352.

23. Hungary (?), collection of the MoD. Military History Institute and Museum.

${ }^{123}$ The close parallels of the analyzed sword are marked with italics. The so-called Letten and Erbenheim type is intentionally omitted from the list because in my view, their blade structure differs from that of the sword discussed here.
24. Innsbruck-Hötting (Austria, Tyrol), grave, Stätzling type: WAGNER 1943, 79, Taf. 6.14; SCHAUER 1971, 145, Taf. 63.434.

25. Italy, unprovenanced, Allerona type: PERONI 1970, 69, Taf. 23.162.

26. Kallithea (Greece, Attica), grave, Naue IIC type: CATling 1956, 112; Giannopoulos 2008, 213-219, Abb. 31-32.

27. Närke/Nerike (Sweden, Svealand), unknown context, "sword with extended tang": SPROCKHOFF 1931, 95, Taf. 7.4

28. Krklino/Raštani (Macedonia, Bitola), stray find, Stätzling type: HARDING 1995, 49-50, Taf. 20.173.

29. Lago Trasimeno (Italy, Umbria), private collection, Allerona type: AnCONA 1886, 10, Tav. 3.44; NAue 1903, Taf. 7.2; PerOni 1970, 66, Taf. 22.155.

30. Lovasberény (Hungary, Fejér), hoard, D type: Holste 1951, 13, Taf. 22.12; KemenCzei 1988, 66, Taf. 39.356; Mozsolics 1985, 144-145, Taf. 246.2.

31. Mesara (Greece, Crete), stray find, Naue IIC type: Kilian-DirlmeiER 1993, 97, Taf. 36.241.

32. Mouliana (Greece, Crete), Tholos B, Naue IIC type: Kilian-Dirlmeier 1993, 97, Taf. 36.242.

33. Mouliana (Greece, Crete, Siteia/Lasithi), Tholos A, Naue IIC type: KILIAN-DiRLMIER 1993, 97, Taf. 37.247.

34. Montegiorgio (Italy, Ascoli Piceno, Marche), unknown context, Allerona type: PERONI 1961, 139; PERONI 1970, 69, Taf. 23.163.

35. Morava estuary-Kulić-Salinac (Serbia, Smederevo), stray find, Stätzling type: HARDING 1995, 50, Taf. 21.174.

36. Nadap (Hungary, Fejér), hoard, D type: MAKKAY 2006, Pl. 26.48

37. Narde Frattesina (Italy, Rovigo), Grave 227, Allerona type: EDER-Jung 2005, 490.

38. Naxos (Greece, Kykladen, Grotta), Chamber grave A, Naue IIC type: KiliAN-DirLmeIR 1993, 97, Taf. 36.243.

39. Naxos (Greece, Kykladen, Kamini), Chamber grave A, Naue IIC type: Kilian-Dirlmeier 1993, 97, Taf. 37.244 .

40. Unknown, Stätzling type: COWEN 1955, 145, Taf. 63.435; SCHAUER 1971, 145, Taf. 63.435.

41. Palaiopyrgos (Greece, Levidi, Arcadia), unknown context, Stätzling type: HARDING 1995, 50.

42. Paks area (Hungary, Tolna), stray find, D type: KEMENCZEI 1988, 66, Taf. 39.357.

43. Pavelsko (Bulgaria, Smoljan), unknown context, Naue IIC type: HänSEL 1970, 36, Abb. 2.1; KILIANDiRLMEIER 1993, 97-98, Taf. 38.250.

44. Pölöske (Hungary, Zala), hoard, D type: SzÉCHENYI 1887, I. t. 8; KeMENCZEI 1988, 64, Taf. 38.349.

45. Prilep-Bolnica (Macedonia, Prilep), Grave 2, Stätzing type: HARDING 1995, 51, Taf. 21.180.

46. Rouen (France, Seine-Maritime), river find, Stätzling type: COWEN 1955, 133, Nr. 7, Taf. 7.7.

47. Rovereto/Leno river (Italy, Trentino), river find, Allerona type: Bulletino di Paletnologia Italiana 1898, 260; PERONI 1970, 69, Taf. 23.160.

48. San Benedetto in Perillis (Italy, L'Aquila, Abruzzi), grave, Allerona type: PERONI 1961, tav. I. 4; PERONI 1970, 66, Taf. 22.156. 
49. Sárbogárd-Rétszilas-Jurcsekpuszta (Hungary, Vas), stray find, D type: KeMENCZEI 1988, 66, Taf. 39.358.

50. Schiste Odos (Greece, Phocis), grave, Stätzling type: CATLING 1956, 112, Nr. 9.

51. Siteia area (Greece, Crete), unknown context, Naue IIC type/Stätzling type: KILIAN-DiRLMEIER 1993, 97, Taf. 36.240; HARDING 1995, 50.

52. Sisak (Croatia, Kupa), stray find, Stätzling type: VINSKI-GASPARINI 1973, 219, Tab. 26.11; HARDING 1995, 49 , Taf. 20.172.

53. Škocjan-Mušja jama (Slovenia, Sežana), hoard, Stätzling type: SzOMBATHY 1913, 143, Abb. 79; HARDING 1995, 51, Taf. 21.178.

54. Slavonski Brod-Livadićeva ulica 7 (Croatia, Slavonski Brod), hoard, Stätzling type: HARDING 1995, 50, Taf. 61.B-64.A.

55. Stätzling (Germany, Bavaria), unknown context, Stätzling type: COWEN 1955, 132, Taf. 7.1; SCHAUER 1971, 145, Taf. 64.436.

56. Szentgáloskér (Hungary, Somogy), hoard, D type: Hampel 1886, CXIX. tábla 31; KemencZei 1988, 65, Taf. 38.350.

57. Szombathely (Hungary, Vas), stray find, D type: Cowen 1955, 129, Taf. 6.1; Kemenczei 1988, 66, Taf. 39.359.

58. Tatabánya (Hungary, Komárom-Esztergom), grave, D type: Cowen 1955, 77, Taf. 7.1.

59. Tiszalök-Középső-dülő (Hungary, SzabolcsSzatmár-Bereg), hoard, D type: KEMENCZEI 1967, 23, Taf. 2.1; KemenCZEI 1988, 66, Taf. 38.351.

60. Trenčianske Bohuslavice/Bogoszló (Slovakia, Trenčin), hoard, Stätzling Type: NovOTNÁ 1970, Taf. XII.

61. Tirintha/Tiryns (Greece, Argolis), hoard, Stätzling type: CATLING 1956, 111, Nr. 5.

62. Vajze (Albania, Vlore), Mound 2/grave, Naue IIC type: Kilian-DiRLmeier 1993, 98, Taf. 38.251.F.

63. Vajze (Albania, Vlore), Mound 1/Grave 7, Naue IIC type: Prendi 1975, 116, Pl. I.4; Kilian-DirlmeIER 1993, 98, Taf. 38.252.

64. Veliko Nabrđe (Croatia, Đakovo), hoard, Stätzling type: VINSKI-GASPARINI 1973, 186, 221, Tab. 45.2; HARDING 1995, 50, Taf. 21.177.

65. Vermeş/Krassóvermes (Romania, BistrițaNăsăud), unknown context, Stätzing type: BADER 1991, 102, Taf. 24.252

66. Vrana (Croatia, Biograd), stray find, Stätzling type: HARDING 1995, 51, Taf. 21.179.

67. Vranezi/Orchomenos (Greece, Livadeia, Boiotia), grave, Naue IIC type: CATLING 1956, 113; KILIAN-DiRlmeIER 1993, 97, Taf. 38.249.

List II. Conical helmets (ClAuSING 2003b; MÖRTZ 2011; MÖDLINGER et al. 2013)

1. Biecz/Beitzsch (Poland, Zielnogórskie), hoard: UndSET-Mestorf 1882, Taf. 20.10; HenCKEN 1952, Fig. I, Pl. 2.

2. Bonyhád (Hungary, Tolna), hoard: Mozsolics 1985, 102-104, Taf. 40.14.

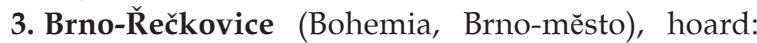
SALAŠ 2002, 265-267, 270, Fig. 6.11, Fig 12.

4. Dunaföldvár (Hungary, Tolna), stray find: SzABó 1994, 219, 1. kép 1-4.
5. Greece, unprovenanced: MöDLINGER et al. 2013, Fig. 2.9.

6. Keresztéte (Hungary, Borsod-Abaúj-Zemplén), hoard: Mozsolics 1955, 42, Fig. 7.7.

7. Knossos (Greece, Crete), grave: HENCKEN 1952, Pl. 1; HoOD-DE JONG 1952, 252, 256, Taf. 50-52a.

8. Lúčky/Lucski (Slovakia, Litpov), uncertain hoard: MERHART 1940, 11, Abb. 2.5.

9. Hungary (?), collection of the MoD. Military History Institute and Museum.

10. Nadap (Hungary, Fejér), hoard: Petres 1982, 57, Abb. 1.a-b; MAKKAY 2006, Pl. I.

11. Oranienburg (Germany, Brandenburg), river find: SPROCKHOFF 1930, 44, Taf. 9.a.

12. Sâg/Sîg/Felsőszék (Romania, Sălaj), hoard: SOROCEANU-LAKÓ 1981, 147, Abb. 9.4.

13. Spišská Belá/Zipser Bela/Szepesbéla (Slovakia, Prešov), hoard 1: HENCKEN 1971, 33, Abb. 15f-h.

14. Žaškov/Zsaskó (Slovakia, Dolný Kubín), hoard: HenCKen 1971, 37, Abb. 17a-c.

List III. Greaves, Clausing's Group 1, Variant A2 (Clausing 2003a)

1. Bodrogkeresztúr (Hungary, Borsod-Abaúj-Zemplén), hoard: KemENCZEI 2003, Taf. 7.19.

2. Bonyhád area (Hungary, Tolna), hoard: WOSINSKY 1890, III. t. 12.

3. Brandgraben (Austria, Styria), hoard: WindHOLZKONRAD 2008, Abb. 53.

4. Brodski Varoš (Croatia, Slavonski Brod), hoard: VINSKI-GASPARINI 1973, 212, Taf. 55.221.

5. Cannés-Écluse (France, Seine-Maritime), hoard 2: GRAUCHER-ROBERTS 1967, 205, Fig. 46-48.

6. Desmontà (Italia, Verona), hoard: SALZANi 1985, 42.

7. Esztergom-Szentgyörgymező (Hungary, KomáromEsztergom), hoard (No. 1): Mozsolics 1985, 116, Taf. 138.16; JANKOVITS 1997, Fig. 5.

8. Hungary, collection of the MoD. Military History Institute and Museum.

9. Malpensa (Italy, Lombardia), hoard: MiRA BONOMI 1979, 125, Fig. 1.1-2.

10. Nadap (Hungary, Fejér), hoard: MAKKAY 2006, 4. t.

11. Pergine (Italy, Trento), hoard: Fogolari 1943, 73, Abb. 1-4.

12. Poljanci 1 (Croatia, Slavonski Brod), hoard: VINSKIGASPARINI 1973, 218, Taf. 48.19.

List IV. "Pustiměř type" flange-hilted knives (Cat. no. 7) (К̌́íHOvsKỲ 1972, 33; KöSZEGI 1988; CHEBENOVÁ 2012; VELIAČIK 2012)

1. Abasár-Rónya-bérc (Hungary, Heves), settlement: V. SzABÓ 2009, 24-25, 2. kép.

2. Allmannsberg (Germany, Upper Bavaria), grave: MÜller-Karpe 1959a, 308; MÜller-Karpe 1959b, Taf. 197.K.4.

3. Badacsonytomaj (Hungary, Veszprém), hoard: Mozsolics 1949, 26. t. 4-6; Mozsolics 1985, Taf. 233.3-5.

4. Bakonybél-Somhegy (Hungary, Veszprém), stray find: HAMPEL 1880, 61-62, 32. kép. 
5. Beravci (Croatia, Đakovo), hoard: Holste 1951, Taf. 2.2-3.5-6; VINSKI-GASPARINI 1973, 211, Tab. 108.22-23.26.

6. Bereghovo/Beregszász 4 (Ukraine, Beregovo), hoard 4: HAMPEL 1892, 9-10; BERNJAKOVIČ 1960, 350; KoBAL' 2000, 74, Taf. 46B.1.

7. Bešenová/Besenyőfalu (Slovakia, Žilina), hoard: KÜRTI 1930, 179-187; EISNER 1933, 113, Obr. 9.8.a-b; NovotnÁ 1970, 89, Taf. XXV; VELIAČIK 2012, 232, Obr. 4.7; ChebenOvá 2012, 3, Tab. II.34.

8. Bihor/Bihar county (Romania), stray find: HAMPEL 1896, 383, CCXXVI. t. 12.17; ŘíHOvskỲ 1972, 33.

9. Ciecieryzn (Poland, Dominowo), grave 5: GEDL 1984, 31, Taf. 6.49 .

10. Chlapowo (Poland, Dominowo), uncertain hoard: GEDL 1984, 31, Taf. 6.48.

11. Chotín/Hetény 2 (Slovakia, Komárno), Grave 190/55 (according to Chebenová: No. 106): DUŠEK 1957, 90; VELIAČIK 2012, 325, Obr. 4.2; CHEBENOVÁ 2012, 4-5, 14, Tab. II.36.

12. Chotín/Hetény 2 (Slovakia, Komárno), Grave 40/54: DUŠEK 1957, Obr. 12.3; VELIAČIK 2012, 325, Obr. 4.6; CHEBENOVÁ 2012, 4-5, 14, Tab. II.37.

13. Cserszegtomaj-Kőfejtő (Hungary, Veszprém), stray find: KösZEGI 1988, 131, No. 248.

14. Csorva (Hungary, Csongrád) grave 38: TROGMAYER 1963, 93, Taf. XXX. 17.

15. Diviaky nad Nitricou (Slovakia, Prievidza), Grave 4/41: BudíNSKÝ-KRICKA 1962, Obr. 6.8-13; VELIAČIK 2012, Obr. 4.7.

16. Donja Bebrina (Croatia, Slavonski Brod), hoard: Holste 1951, 8, Taf. 15.11.

17. Dvory nad Žitavou (Slovakia, Nové Zámky), Grave 2: VELIAČIK-ROMSAUER 1994, 53; VELIAČIK 2012, 324 Obr. 4.1; ChebenOvÁ 2012, 4, 14, Tab. II.38.

18. Felsőnyék (Hungary, Tolna), stray find: KöszeGI 1988, 140, No. 399.

19. Hostie/Keresztúr (Slovakia, Zlatná Moravce), hoard: CHEBENOVÁ 2012, 4, 14, Tab. III.41.

20. Horná Seč/Felsószecse (Slovakia, Levice), settlement, Horná Seč type: ROMSAUER 1977, 241-242; VELIAČIK 2012, 325, Obr. 4.3.

21. Hungary, unprovenanced: GESSNER 1948, 104, Taf. XI. Abb. 1.

22. Jasenica/Jeszence (Slovakia, Trenčín), grave: ŽIIINCOVÁ 2010, 186, 204, Tab. VIII.6; CHEBENOVÁ 2012, 5, 14, Tab. III.40.

23. Kapuvár (Hungary, Győr-Moson-Sopron), stray find: KöSZEGI 1988, 147, No. 522.

24. Kirchberg am Wagram (Austria, Upper Austria), stray find: К̌íHOVSKỲ 1972, 33, Taf. 9.106.

25. Klástor pod Znievom/Znióváralja 5 (Slovakia, Martin), hoard, Horná Seč type: NovotNá 1970, 100; VELIAČIK 2012, 326, Obr. 4.4.

26. Kunětice (Bohemia, Pardubice), Grave 4: FILIP 1939, 34, 42, Obr. 20.3.

27. Kunětice (Bohemia, Pardubice), Grave 8: FILIP 1939, 34, 42, Obr. 20.4.

28. Krajnik Górny (Poland, Chojna), stray find, similar to the Pustiměr̆ type: GeDL 1984, 32, Taf. 7.51.

29. Lengyel (Hungary, Tolna), stray find: WOSINSKY 1896, 304, LXVI. t. 5.
30. Mezice (Bohemia, Olomouc), stray find: ŘíinOvskỲ 1972, 32, Taf. 9.103.

31. Nyíregyháza-Ér alatti szőlő (Hungary, SzabolcsSzatmár-Bereg), grave: KeMENCZEI 1984, 160, 341, Taf. CXXI.3.

32. Olomouc (Bohemia, Olomouc), stray find: DOHNAL 1961, 59, Obr. 4.4; ŔínOvsKỲ 1972, 32-33, Taf. 9.104.

33. Opole-Groszowice/Groschowitz (Poland, Opole), Grave 11/1925: PETERSEN 1913, 213; GeDL 1984, 31, Taf. 6.50 .

34. Ostrowice/Treptow-Spinnkathen/Spinnkaten (Poland, Ostrowice), cemetery/stray find: KERSTEN 1958, 79, Taf. 82.752c.

35. Ovčiarsko/Juhászi/Ovcsárszko (Slovakia, Žilina), hoard: HAMPEL 1892, 111-112; CHEBENOVÁ 2012, Tab. II.35.

36. Pincehely-Gyánti bevágás (Hungary, Tolna), stray find: SZABÓ 1885, 337; KóSZEGI 1988, 173, No. 931; WOSINSKY 1896, 486 .

37. Porva (Hungary, Veszprém), stray find: DAX et al. 1972, 221, 19. t. 3; KŐSZEGI 1988, 174, No. 947.

38. Pustiměř (Bohemia, Vyškov), grave: ŘíHOVSKỲ 1972, 32, Taf. 9.105.

39. Rezi-hegy (Hungary, Veszprém), stray find: DARNAY 1899, 19.

40. Sankt Martin bei Lofer (Austria, Zell am See), grave: KlOSE 1928, 109-110, Abb. 4.

41. Slovakia, unprovenanced: CHEBENOVÁ 2012, 8, 14, Tab. III.42.

42. Slovakia, unprovenanced: CHEBENOVÁ 2012, 8, 14, Tab. III.43.

43. Slovakia, unprovenanced: CHEBENOVÁ 2012, 9, 14, Tab. III.44.

44. Slovakia or Galanta/Galánta area, unprovenanced: CHEBENOVÁ 2012, 8, 14, Tab. III.45.

45. Somogyszob (Hungary, Somogy), hoard: MozsoLICS 1985, 187, Taf. 249.4

46. Szombathely-Jáky úti temető (Hungary, Vas), hoard: ILON 2002, 154, Abb. 6.1.

47. Tatabánya-Felsógalla (Hungary, KomáromEsztergom), stray find: Mozsolics 1985, Taf. 122.6.

48. Tata-Dunamellék (Hungary, Komárom-Esztergom), uncertain hoard: Mozsolics 1985, 114.

49. Tolnanémedi (Hungary, Tolna), stray find: PATEK 1968, 66; KŐSZEGI 1988, 190, No. 1205; WOSINSKY 1896, 484.

50. Trenčianske Bohuslavice/Bogoszló (Slovakia, Trenčín), hoard: NovOTNÁ 1970, Taf. XIII; VELIAČIK 2012, 332, Obr. 4.5; CheBENOVÁ 2012, 7, 14, Tab. II.39.

51. Variaş/Varjas (Romania, Timişs), hoard: PETRESCUDîMboviȚA 1978, 138, Taf. 221E.5.

52. Velikaya Began' or Zmeevka (Ukraine, Beregovo), uncertain hoard: KOBAL' 2000, 98, Taf. 91.13.

53. Volders (Germany, Tyrol), Grave 18: JOCKENHÖVEL 1971, 89, Taf. 64A.2.

List V. Fuchsstadt type cups (SPROCKHOFF 1930; SOROCEANU 2008; MARTIN 2009, 166-168, Liste 2)

1. Armagh (Ireland, Tamlaght), hoard: WARNER 2004.

2. Abstatt (Germany, Baden-Württemberg), stray find: Schliz 1909, 107, Abb. 42.7; JАСОв 1995, 27, Taf. 5.24.

3. Altensittenbach (Germany, Bavaria), grave: ЈАСОВ 1995, 29, Taf. 5.26. 
4. Banat/Bánát (Romania, Banat), stray find: GoGÂLTAN 1990, 89-91, Abb. 1; SOROCEANU 2008, 49, Taf. 3.12.

5. Basedow (Germany, Mecklenburg-Vorpommern), hoard: LISCH 1871, 134-135; MARTIN 2009, 54-55, Taf. 14.57.

6. Bevaix (Switzerland, Neuenburg), settlement: THRANe 1975, 136, Abb. 80.a.

7. Burgsdorf (Germany, Sachsen-Anhalt), hoard: SprockHoff 1930, 71, Anm. 10; Martin 2009, 55, Taf. 15.63-54.

8. Burladingen (Germany, Baden-Württemberg), grave: MÜLLER-KARPE 1959a, Taf. 207.G; JACOB 1995, 33, Taf. 6.31.

9. Buru/Borrév/Borév (Romania, Cluj), hoard: RosKA 1932, 540, Abb. 2; SOROCEANU 2008, 46-47, Taf. 1.7.

10. Braunsbedra (Germany, Saxony-Anhalt), hoard: OtTo 1955, 164-166, Abb. 3-7, Taf. 50-54; MARTIN 2009, 55, Taf. 14.58-61.

11. Dexheim (Germany, Rhineland-Palatinate), hoard: SPROCKHOFF 1930, 68; JACOB 1995, 27, Taf. 5.23.

12. Dresden-Dobritz (Germany, Saxony), hoard: Coblenz 1952, 144, Abb. 10; Martin 2009, 55, Taf. 16.65.

13. Dötzingen (Germany, Lower Saxony), hoard: SpROCKHOFF 1930, Taf. 18.a-c; JАСов 1995, 26, Taf. 3.13-16.

14. Egyek (Hungary, Hajdú-Bihar), hoard: SöREGI 1936, 58, 18. kép 5; PATAY 1990, 57-58, Taf. 39.86.

15. Ehingen/Danube (Germany, Baden-Württemberg), hoard: SPROCKHOFF 1930, 70; JАСов 1995, 27, Taf. 4.22.

16. Ejstrup (Denmark, Jutland), hoard: SРROCKHOFF 1930,73

17. Érsekvadkert (Hungary, Nógrád), hoard: Mozsolics 1967, Taf. XVIII.5; KeMENCZeI 1984, 147; PATAY 1990, 58, Taf. 40.87.

18. Eschborn (Germany, Main taunus), grave: SprockHOFF 1930, 62; ЈАСов 1995, 19, 33, Taf. 6.33, Taf. 2.7.

19. Northern Germany, unprovenanced: BLEICHER 1980, Abb. 109; MARTIN 2009, 58, Taf. 21.81.

20. Falkenberg (Germany, Brandenburg), grave: AGDE 1936, 173, Abb. 6.a; MARTin 2009, 57, Taf. 20.79.

21. Fuchsstadt (Germany, Bavaria), Grave 1: KRAFT 1926, 182, 186, Abb. 3; MÜLlER-KARPE 1959a, Taf. 207A.7; ЈАСОв 2009, 25, Taf. 2.10.

22. Gernlinden (Germany, Bavaria), grave: REINECKE 1930, Taf. 6; MÜlleR-Karpe 1959b, Taf. 207.d; JАСОв 2009, 27, Taf. 4.19 .

23. Großörner (Germany, Saxony), hoard: HÄNSELHÄNSEL 1997, 39, 44, Abb. 3.1-2, Abb. 4.1-2, Abb. 5.1-2, Abb. 6.1, Abb. 7.1, Abb. 9.2-9; MARTIN 2009, 55-56, 58, Taf. 16.66-69, Taf. 17.70, Taf. 18.71, Taf. 21.80.

24. Grünwald (Germany, Bavaria), Grave 1: MÜLLERKARPE 1959b, Taf. 207.c; JАСОв 2009, 26, Taf. 3.11.

25. Haunstetten (Germany, Bavaria), Grave 23: BAKKER 1987, 68, Abb. 41.3; ЈАСов 1995, 30, Taf. 5.28A.

26. Hitzacker (Germany, Lüchow-Dannenberg), unknown context: SPROCKHOFF 1930, 72, Taf. 10.e.

27. Langengeisling (Germany, Bavaria), Grave 4: KRÄMER 1952, 264, Abb. 2.1; MÜLler-KARPE 1959b, Taf. 207.h; ЈАСОВ 2009, 27, Taf. 4.20.

28. Linz a. d. Donau (Austria, Upper Austria), hoard: MAHR 1914, 285; PRÜSSING 1991, 23, Taf. 1.9.

29. Ljubljanica river/Bevke (Slovenia, Vrhnika), river find: ŠINKOVEC 1995, 123, Tab. 36.263.
30. Mansfeld (Germany, Saxony), hoard: SPROCKHOFF 1930, 71, Taf. 16.d; MARTIN 2009, 56, Taf. 18.73.

31. Nierstein (Germany, Rhineland-Palatinate), grave: THRANE 1965, Abb. 2b; JАСОв 2009, 26, Taf. 3.12.

32. Moigrad/Mojgrád (Romania, Sălaj), Hoard 1: Nestor 1935, Abb. 1.3, Taf. 2.13; Petrescu-DîMbovițA 1978, 143, Taf. 234.3; SoroceAnu 2008, 47, Abb. 2, Taf. 2.9.

33. Möhrigen (Germany, Baden-Württemberg), grave: SprockHOFF 1930, 69; Kimming 1940, Taf. 33.14; JАCOB 2009, 26-27, Taf. 4.17.

34. Mörigen (Switzerland, Bern), settlement: GROSS 1883, 113, Taf. 22.7.

35. Nystad (Norway, Salten), hoard: THRANE 1965, 159, Abb. 2.a.

36. Oberboihingen (Germany, Baden-Württemberg), grave: Косн 1967, 58, Taf. 78.1; ЈАсов 2009, 27, Taf. 4.18 .

37. Pavlovka (Ukraine, Odesskaya oblast), grave: SPROCKHOFF 1930, 75.

38. Pişcolt/Piskolt (Romania, Satu Mare), uncertain hoard: NÉMETI 1972, Fig. 2; SOROCEANU 2008, 47-48, Abb. 3.a-c.

39. Poznań-Wielka Starolęka 1 (Poland, Poznań), hoard: GEDL 2001, 16, Taf. 1.1-3.

40. Pößneck-Slettheim (Germany, Thuringia), hoard: Feustel 1967, 258, Taf. 45.a; MARTin 2009, 56-57, Taf. 19.74 .

41. Preten (Germany, Mecklenburg-Vorpommern), grave: SPROCKHOFF 1930, 72-73.

42. Rassing (Austria, MG Kapelin, VB St. Pölten), hoard: NEUGEBAUER et al. 1998-1999, Abb. 22.

43. Reichenbach (Germany, Baden-Württemberg), stray find: ЈАСОВ 2009, 27, Taf. 4.21.

44. Rohov/Rochow (Bohemia, Opava), hoard: GEDL 2001, 16, Taf. 2.4.

45. Saint-Chély-du-Tarn (France, Sainte-Enimie), hoard: MillotTe 1959, 25.

46. Sâncrăieni/Sîncrăieni/Csíkszentkirály (Romania, Harghita), Hoard 1: ZOLTAI 1909, 134, 8. ábra; SOROCEANU 2008, 48, Taf. 3.11.

47. Schussenried (Germany, Baden-Württemberg), grave: MÜlLER-KARPE 1959a, 313, Taf. 207.b.

48. Sengkofen (Germany, Bavaria), grave: FISCHER 1982, 92, Abb. 79; ЈАСов 1995, 28-29, Taf. 5.25.

49. Staaken (Germany, Berlin), hoard: SPROCKHOFF 1930, 73, Taf. 16.a-b; MARTIN 2009, 57, Taf. 19.75-76.

50. Thale (Germany, Saxony), hoard: MARTIN 2009, 57, Taf. 20.78

51. Třtěno/Křěno (Bohemia, Louny), hoard: RiCHLÝ 1894, 80; KYTLICOVÁ 1991, 43-44, Taf. 2.10.

52. "Velem" (Hungary, Vas), unknown context: PATAY 1990, 58, Taf. 40.88.

53. Volders (Austria, Tyrol), Grave 208: PrÜssING 1991, 22-23, Taf. 1.8 .

54. Völs (Austria, Tyrol), Grave 6: WAGNER 1943, 112, Taf. 24.1-4; PRÜSSING 1991, 22, Taf. 1.7.

55. Wollmesheim (Germany, Rhineland-Palatinate), grave: SPRATER 1928, 95, Abb. 102; JACOB 1995, 30, Taf. 5.28 .

56. Wörschach (Austria, Styria), grave: MODRIJAN 1953, 24, Abb. C.3c; PRÜssing 1991, 23, Taf. 1.10. 


\section{LITERATURE}

Agde, Hellmut

1936 Lausitzer Grabhügel bei Falkenberg, Kr. Liebenwerda. Jahresschrift für die Vorgeschichte der sächsisch-thüringischen Länder 24, 173-183.

ANCONA, AMILCARE

1886 Le armi, le fibule e qualche altro cimelio della sua collezione archeologica. Milano.

ANDREA, ZHANETA

1985 Kultura Ilire e Tumave në Pellgun e Korçës. Tiranë.

ARMBRUSTER, BARBARA REgINE

2002 Goldschmiedekunst und Bronzetechnik. Studien zum Metallhandwerk der Atlantischen Bronzezeit auf der Iberischen Halbinsel. Monographies instrumentum 15. Montagnac.

BADER, TIBERIUS

1991 Die Schwerter in Rumänien. Prähistorische Bronzefunde IV/8. Stuttgart.

BAKKER, LOTHAR

1987 Funde der Glockenbecher- und Urnenfelderkultur in Haunstetten, Stadt Augsburg, Schwaben. Das

BANNER JÁNOS

archäologische Jahr in Bayern (Darmstadt) (1986) 68-69.

1944-1945 Bronzleletek Hódmezővásárhely határában (Trouvailles de bronze des environs de Hódmezővásárhely). Archaeologiai Értesítő (Budapest) 3/5-6, 29-42.

BERNJAKOVIČ, KONSTANTIN

1960 Bronzezeitliche Hortfunde vom rechten Ufergebiet des Oberen Theisstales (Karpatoukraine USSR). Slovenská Archeológia (Nitra) 8/2, 325-392.

Besl, Christoph-MÖdlinger, MARIANNE-NTAFlos, ThEOdOROS-SAlasberger, DieTMAR

2010 Untersuchungen zu Herstellung und Gebrauch eines Schalenknaufschwertes aus Unterradlberg, Niederösterreich (Analysis of the manufacture and use of a Bronze age sword of Schalenknauf-type from Unterradlberg, Lower Austria). Fundberichte Österreichs (Wien) 48, 2009, 47-56.

Bietti Sestieri, Anna Maria-Salzani, Luciano-Giardino, Claudio-Verly, Georges

2013 Ritual treatment of weapons as a correlate of structural change in the Italian LBA communities: the bronze hoard of Pila del Brancon (Nogara, Verona). Rivista di Scienze Preistoriche (Firenze) 63, 155-169.

BLEICHER, WILHELM

1980 Museum Hohenlimburg - Museumsführer und Auswahlkatalog aus Anlaß des 750jährigen Bestehens der Siedlung Hohenlimburg. Hagen/Dorau.

BORCHHARDT, JÜRGEN

1972 Homerische Helme. Helmformen der Ägais im ihren Beziehungen zu orientalischen und europäischen Helmen in der Bronze- und frühen Eisenzeit. Mainz am Rhein.

BORN, HERMANN-HANSEN, SVEND

1991 Antike Herstellungstechniken: Ungewöhnliche Klingenreparaturen an einem spätbronzezeitlichen Vollgriffschwert. Acta Praehistorica et Archaeologica (Berlin) 23, 147-157.

2011 Helme und Waffen Alteuropas 9. Sammlung Axel Guttmann. Berlin-Mainz.

BOUZEK, JAN

1981 Die Anfänge der blechernen Schutzwaffen im östlichen Mitteleuropa. In: Lorenz, H. (Hrsg.): Studien zur Bronzezeit. Festschrift für Wilhelm Albert von Brunn. Mainz/Rhein, 21-38.

BRANDHERM, DIRK

2011 Bronzezeitliche Kamm- und Hörnerhelme - Überlegungen zu Ursprung, Verbreitung und symbolischem Gehalt. In: Dietz, U. L.-Jockenhövel, A. (Hrsg.): Bronzen im Spannungsfeld zwischen praktiker Nutzung und symbolischer Bedeutung. Prähistorische Bronzefunde XX/13. Stuttgart, 39-54.

BRUNN, WilHELM AlberT VON

1968 Mitteldeutsche Hortfunde der jüngeren Bronzezeit. Römisch-Germanische Forschungen 29. Berlin.

BRÜCK, JOANNA-FONTIJN, DAVID

2013 The Myth of the Chief: Prestige Goods, Power, and Personhood in the European Bronze Age. In: Harding, A.-Fokkens, H. (eds): The Oxford Handbook of the European Bronze Age. Oxford, 197-215.

BUDÍNSKÝ-KRIČKA, VOJTECH

1962 Prispevok k študiu kultury popolnicovych polí nad Hornou Nitrou (Ein Beitrag zum Studium der Urnenfelderkultur im oberen Nitratal). Študijné Zvesti Archeologického Ústavu Slovenskej Akadémie

BRADLEY, RICHARD Vied (Nitra) 9, 123-130.

2005 Ritual and Domestic Life in Prehistoric Europe. London-New York.

Bullettino di Paletnologia Italiana

1886 Bullettino di Paletnologia Italiana (Notizie diverse) 12, 261. 
BunNEFELD, JAN-HEINRICH-SCHWENZER, STEFAN

2011 Traditionen, Innovationen und Technologietransfer - Zur Herstellungstechnik und Funktion älterbronzezeitlicher Schwerter in Niedersachsen. Praehistorische Zeitschrift (Berlin) 86/2, 207-253.

CATLing, Hector WiLliam

1956 Bronze Cut-and-Thrust Swords in the Eastern Mediterranean. Proceedings of the Prehistoric Society (Cambridge) 7, 102-125.

1961 A new bronze sword from Cyprus. Antiquity (Cambridge) 35, 115-122.

CHEBENOVÁ, PETRA

2012 Nálezy bronzových nožov z doby bronzovej na územi Sloveska (Funde von Bronzemessern aus der Bronzezeit auf dem Gebiet der Slowakei). Slovenská Archeológia (Nitra) 60/1, 1-36.

CHILDE, Vere GoRdON

1948 The Final Bronze Age in the Near East and in Temperate Europe. Proceedings of the Prehistoric Society (Cambridge) 14, 177-195.

Clausing, Christof

1996 Urnenfelderzeitliche Vorläufer eisenzeitlicher Rippenzisten? Archeologisches Korrespondenzblatt (Mainz) 26, 413-431.

2003a Geschnürte Beinschienen der späten Bronze- und älteren Eisenzeit. Jahrbuch des Römisch-Germanischen Zentralmuseums Mainz 49, 2002, 149-187.

2003b Spätbronze- und eisenzeitliche Helme mit einteiliger Kalotte. Jahrbuch des Römisch-Germanischen Zentralmuseums Mainz 48/1, 2001, 199-226.

2005 Untersuchungen zu den urnenfelderzeitlichen Gräbern mit Waffenbeigaben vom Alpenkamm bis zur Südzone des Nordischen Kreises. Eine Analyse ihrer Grabinventare und Grabformen. British Archaeological Reports - International Series 1375. Alden.

COBLENZ, WERNER

1952 Der Bronzegefäßfund von Dresden-Dobritz. Arbeits- und Forschungsberichte der Sächsischen Bodendenkmalpflege (Dresden) 2, 135-161.

COLINI, G. ANGELO

1900 Suppellettile della tomba di Battifolle (Cortona) ed altri oggetti areaiei dell'Etruria. Bulletino di Paletnologia Italiana (Roma) 26, 133-151.

COWEN, JOHN D.

1955 Einführung in die Geschichte der bronzenen Griffzungenschwerter in Süddeutschland. Bericht der Römisch-Germansichen Kommission (Berlin) 33, 52-155.

DARNAY KÁLMÁN

1899 Sümegh és vidékének őskora. Archaeologiai Közlemények (Budapest) 22, 5-85.

Dax MARGit-ÉRi István-Mithay SÁndor-Palágyi SZILVIA-Torma IstVÁn

1972 Veszprém megye Régészeti Topográfiája 4. A pápai és zirci járás. Torma I. (szerk.), Budapest.

DEHN, WOLFGANG

1980 Zur Beinschiene von Schäfstall bei Donauwörth. Zeitschrift des historischen Vereins für Schwaben und Neuburg (Augsburg) 74, 29-33.

DOHNAL, VÍT

1961 Žárový hrob z konce doby bronzové u Hodonína (Spätbronzezeitliches Urnengrab aus Hodonín). Pravěk Východní Moravy (Brno) 2, 53-67.

DOLFINI, ANDREA

2004 Le simbologie ornitomorfe in Italia durante il Bronzo Finale: Prospettive di Analisi. Preistoria e Protostoria in Etruria. Miti Simboli Decorazioni Ricerche e scavi (Milano) 1, 279-305.

DRIEHAUS, JÜRGEN

1961 Röntgenuntersuchungen an bronzenen „Vollgriffschwertern”. Germania (Berlin) 39, 22-31.

DUŠEK, MiKULÁŠ

1957 Halštatská kultúra chotínskej skupny na Slovensku (Die Hallstattkultur der Chotín-Gruppe in der Slowakei). Slovenská Archeológia (Nitra) 5/1, 73-173.

EDER, BRIGITTA-JUNG, ROBERT

2005 On the Character of Social Relations between Greece and Italy in the $12^{\text {th }} / 11^{\text {th }}$ Cent. BC. In: Laffineur, R.-Greco, E. (eds): Emporia. Aegeans in the Central and Eastern Mediterranean. Proceedings of the $10^{\text {th }}$ International Aegean Conference/10 $10^{\text {th }}$ Rencontre égéenne internationale: Athens, Italian School of Archaeoloy. 14-18 April 2004. Aegaeum 25. Liège, 485-495.

EISNER, JAN

1933 Slovensko v Pravěku. Práce Učené Společnosti Šafaříkovy v Bratislavě 13. Bratislava.

FALKENSTEIN, FRANK

2006-2007 Gewalt und Krieg in der Bronzezeit Mitteleuropas. Bericht der Bayerischen Bodendenkmalpflege (München) 47/48, 33-52. 
FEUSTEL, RUdOLF

1967 Ein Bronzetassen-Depot aus dem Orlagau. Ausgrabungen und Funde (Berlin) 12/5, 258-262.

FILIP, JAN

1939 Lužická Kultura v Československu I (Die Lausitzer Kultur in Böhmen und Mähren I). Památky archeologické (Praha) 41, 14-51.

FISCHER, THOMAS

1982 Eine Bronzetasse der Urnenfelderzeit von Sengkofen, Gemeinde Mintraching, Landkreis Regensburg, Oberpfalz. Das Archäologische Jahr in Bayern (Stuttgart) 1981, 92-93.

FOGOLARI, GIULIA

1943 Beinschienen der Hallstattzeit von Pergine (Valsugana). Wiener Prähistorische Zeitschrift 30, 73-81.

FOLTINY, STEPHAN

1955 Zur Chronologie der Bronzezeit des Karpatenbeckens. Bonn.

FONTIJN, DAVID

2002 Sacrificial Landscapes. Cultural Biographies of Persons, Objects and 'Natural' places in the Bronze Age

GEDL, MAREK of Southern Netherlands, c. 2300-600 BC. Leiden.

1984 Die Messer in Polen. Prähistorische Bronzefunde VII/4. München.

2001 Die Bronzegefäße in Polen. Prähistorische Bronzefunde II/15. Stuttgart.

GENER, MARC

2011 Integrating form, function and technology in ancient swords. The concept of quality. In: Uckelmann, M.-Mödlinger, M. (eds): Bronze Age Warfare: Manufacture and Use of Weaponry. British Archaeological Reports - International Series 2255. Oxford, 117-123.

GESSNER, VERENA

1948 Ein seltener Messertyp der späten Bronzezeit. Jahrbuch der Schweizerischen Gesellschaft für Urgeschichte (Basel) 39, 103-105.

GianNOPOULOS, THEODOROS G.

2008 Die letzte Elite der mykenischen Welt. Achaia in mykenischer Zeit und das Phänomen der Kriegerbestattungen im 12.-11. Jahrhundert v. Chr. Universitätsforschungen zur Prähistorischen Archäologie 152, Bonn.

GOGÂLTAN, FLORIN

1990 Două vase hallstattiene de bronz din colecțile Muzeului Banatului din Timişoara (Zwei hallstattzeitliche Bronzegefäße in den Sammlungen des Banater Museums von Timişoara). Banatica 10, 89-94.

GRAUCHER, GILLES-ROBERT, YvES

1967 Les dépôts de bronze de Cannes-Écluse (Seine-et-Marne). Gallia préhistoire (Paris) 10, 169-223.

GROSS, VICTOR

1883 Les protohelvètes ou les premiers colons sur les bords des lacs de Bienne et de Neuchâtel. Avec préface

HAMPEL, JÓZSEF de M. le prof Virchow. Berlin.

1877 A magyarhoni bronzkardokról. Archaeologiai Értesítő (Budapest) 11/2, 41-55.

1880 Magyarhoni régészeti leletek repertoriuma. Második Közlemény. Archaeologiai Közlemények (Budapest) $13 / 2,32-75$.

1886 A bronzkor emlékei Magyarhonban. I. rész: Képes atlasz. Budapest.

1892 A bronzkor emlékei Magyarhonban. II. rész: A leletek statisztikája. Budapest.

1896 A bronzkor emlékei Magyarhonban. III. rész: Áttekintő ismertetés. Budapest.

HANSEN, SVEND

1994 Studien zu den Metalldeponierungen während der älteren Urnenfelderzeit zwischen Rhônetal und Karpatenbecken. Teil 1. Universitätsforschungen zur Prähistorischen Archäologie 21. Bonn.

1996 Bemerkungen zur zeitlichen Stellung der Hortfunde des Typus Gyermely. Archäologisches Korrespondenzblatt (Mainz) 26, 433-441.

2008 Bronzezeitliche Horte als Indikatoren für „,andere Orte”. Das Altertum (Berlin) 53, 291-314.

HÄNSEL, BERNHARD

1970 Bronzene Griffzungenschwerter aus Bulgarien. Praehistorische Zeitschrift (Berlin) 45, 26-41.

HÄNSEL, ALIX

1997 Das metallene Tafelgeschirr im Opfer. In: Hänsel, A.-Hänsel, B. (Hrsg.): Graben an die Götter. Schätze der Bronzezeit Europas. Bestandkatalog Bd. 4. Berlin, 83-86.

HÄNSEL, ALIX-HÄNSEL, BERNHARD

1997 Herrscherinsignien der älteren Urnenfelderzeit. Ein Gefäßdepot aus dem Saalgebiet Mitteldeutschlands.

HARDING, ANTHONY

Acta Praehistorica et Archaeologica (Berlin) 29, 39-68.

1984 The Mycenaeans and Europe. London.

1995 Die Schwerter im ehemaligen Jugoslawien. Prähistorische Bronzefunde IV/14, Stuttgart. 
2007 Warriors and Weapons in Bronze Age Europe. Budapest.

2008 Razors and Male Identity in the Bronze Age. In: Dobiat, C.-Ettel, P.-Fless, F. (Hrsg.): Durch die Zeiten... Festschrift für Albrecht Jockenhövel zum 65. Geburtstag. Internationale Archaeologie Studia honoraria 28. Rahden/Westf., 191-195.

HARRISON, RICHARD J.

2004 Symbols and Warriors. Images of the European Bronze Age. Bristol.

HENCKEN, HuGH

1952 Beitzsch and Knossos. Proceedings of the Prehistoric Society (Cambridge) 18, 36-46.

1971 The Earliest European Helmets. Bronze Age and Early Iron Age. Cambridge/Massachusetts.

HiLLER, STEFAN

1991-1992 Österreich und die mykenisch-mitteleuropäischen Kulturbeziehungen. Jahreshefte des Österreichischen Archäologischen Institutes in Wien 61, 1-19.

HOLSTE, FRIEDRICH

1951 Hortfunde Südosteuropas. Marburg/Lahn.

Hood, Martin Sinclair FranKland-Jong, PieT DE

1952 Late Minoan Warrior-Graves from Ayios Ioannis and the New Hospital Site at Knossos. Annual of the British School at Athens 47, 243-277.

HORVÁTH PÉTER

1997 Egy késő bronzkori (i. e. XII-X. századi) bronz lábvért restaurálása (The restorations of a Late Bronze Age [12th-10th century BC] bronze leg armour). Mútárgyvédelem (Budapest) 26, 141-146.

ILON, GÁBOR

2002 Ein spätbronzezeitlicher Hortfund aus Szombathely (Steinamanger), Kom. Vas (Ungarn). Das Altertum (Berlin) 47, 149-169.

2014 Der Anfang der Urnenfelderzeit (Bz D) im Bakony-Gebirge (Ungarn). Das Gräberfeld und die mehrschichtige Siedlungen der Spät-Hügelgräberzeit und der Früh-Urnenfelderzeit in der Gemarkung von Németbánya. In: Ložnjak Dizdar, D.-Dizdar, M. (eds): The Beginning of the Late Bronze Age between the Eastern Alps and the Danube. Proceedings of the International conference in Osijek, October 20-22, 2011. Zagreb, 101-177.

JACOB, CHRISTINA

1995 Metallgefäße der Bronze- und Hallstattzeit in Nordwest-, West- und Süddeutschland. Prähistorische

JANKOVITS, KATALIN Bronzefunde II/9. Stuttgart.

1992 Spätbronzezeitliche Hügelgräber in der Bakony-Gegend. Acta Archaeologica Academiae Scientiarum Hungaricae (Budapest) 44, 3-81.

1997 La riconstruzione di due nuovi schinieri del tipo a lacci dall' Ungheria. Acta Archaeologica Academiae Scientiarum Hungaricae (Budapest) 49, 1-21.

1999-2000 Neue Angaben zu dem Depotfund von Pila del Brancon, Nogara (Verona) zu den Bronzeblechen vom Depotfund. Acta Archaeologica Academiae Scientiarum Hungaricae (Budapest) 51, 189-205.

JíRÁŇ, LUBOŠ

2002 Die Messer in Böhmen. Prähistorische Bronzefunde VII/5. Stuttgart.

JOCKENHÖVEL, ALBRECHT

1971 Die Rasiermesser in Mitteleuropa (Süddeutschland, Tschechoslowakei, Österreich, Schweiz). Prähistorische Bronzefunde VIII/1. München.

1974 Ein reich verziertes Protovillanova-Rasiermesser (Ein Beitrag zum urnenfelderzeitlichen Symbolgut). In: Müller-Karpe, H. (Hrsg.): Beiträge zu italienischen und griechischen Bronzefunden. Prähistorische Bronzefunde XX/1. München.

1982 Zu den ältesten Tüllenhämmern aus Bronze. Germania (Berlin) 60, 459-467.

JÓSA, ANDRÁS

1893 Szabolcsmegyei bronzleletekről. Archaeologiai Értesítő (Budapest) 13, 165-170.

Kalla GÁBor-RacZKy PÁl-V. SZABó GÁBOR

2013 Ünnep és lakoma a régészetben és az írásos forrásokban. Az őskori Európa és Mezopotámia példái alapján. In: Déri, B. (szerk.): Antion könyvek 2. Convivium. Az Eötvös Loránd Tudományegyetem Bölcsészettudományi Karán 2012. november 6-7-én tartott vallástudományi konferencia elóadásai. Budapest, 11-46.

KARAVANIĆ, SNJEŽANA

2009 The Urnfield Culture in Continental Croatia. British Archaeological Reports - International Series 2036. Oxford.

KEMENCZEI, TiBOR

1967 A tiszalöki kardlelet (Bronzener Schwertfund von Tiszalök). Jósa András Múzeum Évkönyve (Nyíregyháza) 10, 23-29. 
1979 Neuer Bronzehelmfund in der Prähistorischen Sammlung des Ungarischen Nationalmuseums (Új bronzsisak-lelet a Magyar Nemzeti Múzeum Őskori Gyújteményében). Folia Archaeologica (Budapest) 30, 79-89.

1984 Die Spätbronzezeit in Nordostungarn. Archaeologia Hungarica. Budapest.

1988 Die Schwerter in Ungarn I (Griffplatten-, Griffangel- und Griffzungenschwerter). Prähistorische Bronzefunde IV/6. München.

1991 Die Schwerter in Ungarn II (Vollgriffschwerter). Prähistorische Bronzefunde IV/9. Stuttgart.

2003 Der erste Bronzefund von Bodrogkeresztúr. Archaeologiai Értesítő (Budapest) 128, 17-49. KERSTEN, KARL

1958 Die Funde der älteren Bronzezeit in Pommern. 7. Beiheft zum Atlas der Urgeschichte. Hamburg.

KILIAN-DiRLMEIER, IMMA

1993 Die Schwerter in Griechenland (außerhalb der Peloponnes), Bulgarien und Albanien. Prähistorische

KIMMING, WOLFGANG

Bronzefunde IV/12. Stuttgart.

1940 Die Urnenfelderkultur in Baden untersucht aufgrund der Gräberfunde. Römisch-Germanisch Forschung 14. Berlin.

KLOSE, OLIVIER

1928 Ein Flachgrab der frühen Hallstattzeit in St. Martion bei Lofer (Salzburg). Wiener Prähistorische Zeitschrift 15, 108-111.

KOBAL' Josip V.

2000 Bronzezeitliche Depotfunde aus Transkarpatien (Ukraine). Prähistorische Bronzefunde XX/4. Frankfurt.

$\mathrm{KOCH}$, EWALD

1967 Oberboihingen. Fundberichte aus Schwaben (Stuttgart) 18/2, 58.

KOPYTOFF, IGOR

1986 The cultural biography of things: commodization as process. In: Appadurai, A. (ed.): The Social Life of KOSSACK, GEORG

Things. Cambridge, 64-91.

1995 Mitteleuropa zwischen dem 13. und 8. Jahrhundert v. Chr. Geb. Geschichte, Stand und Probleme der Urnenfelderforschung. In: Schauer, P. (Hrsg.): Beiträge zur Urnenfelderzeit nördlich und südlich der Alpen. Ergebnisse eines Kolloquiums. Römisch-Germanisches Zentralmuseum. Forschungsinstitut für KÖSZEGI FRIGYES Vor- und Frühgeschichte. Monographien 35. Bonn, 1-64.

1988 A Dunántúl története a késő bronzkorban (The History of Transdanubia during the Late Bronze Age). BTM Múhely 1. Budapest.

KRAFT, GEORG

1926 Beiträge zur Kenntnis der Urnenfelderkultur in Süddeutschland („Hallstatt A“). Bonner Jahrbuch 131, 154-211.

KRAHE, GÜNTHER

1980 Beinschiene der Urnenfelderzeit von Schäfstall, Stadt Donauwörth, Landkreis Donau-Ries, Schwaben. Archäologisches Jahr Bayern (Stuttgart) 76-77.

KRÄMER, WOLFGANG

1952 Neue Grabfunde der frühen Urnenfelderzeit aus der Umgebung von Erding (Oberbayern). Germania (Berlin) 30, 263-267.

KRISTIANSEN, KRISTIAN

1984 Krieger und Häuptlinge in der Bronzezeit Dänemarks. Ein Beitrag zur Geschichte des bronzezeitlichen Schwertes. Jahrbuch des Römisch-Germanischen Zentralmuseums (Mainz) 31, 187-208.

1999 The Emergence of Warrior Aristocracies in Later European Prehistory and Their Long-Term History. In: Carman, J.-Harding, A. (eds): Ancient Warfare. Archaeological Perspectives. Gloucestershire, 175-189.

Kuijpers, MAikel H. G.

2008 Bronze Age metalworking in the Netherlands (c. 2000-800 BC). A research into the preservation of metallurgy related artefacts and the social position of the smith. Leiden.

KÜRTI, JULIUS

1930 Archeologické nálezy z Bešeňovej (Liptov). Sborník Muzeálnej slovenskej spoločnosti (Bratislava) 24, 179-188.

KYTLICOVÁ, OLGA

2007 Jungbronzezeitliche Hortfund in Böhmen. Prähistorische Bronzefunde XX/12. Stuttgart.

LIPPERT, ANDREAS

2011 Die zweischaligen ostalpinen Kammhelme und verwandte Helmformen der späten Bronze- und frühen Eisenzeit. Salzburg. 
LISCH, GEORG CHRISTIAN FRIEDRICH

1871 Bronzeschalen von Basedow. Jahrbücher des Vereins für Mecklenburgische Geschichte und Altertumskunde 36, 135.

MAHR, ADOLF

1914 Die älteste Besiedlung des Linzer Bodens. Wiener Prähistorische Zeitschrift 1/4, 278-290.

MAKKAY, JÁNOS

1982 The Earliest Use of Helmets in South-East Europe. Acta Archaeologica Academiae Scientiarum Hungaricae (Budapest) 34, 3-22.

2006 The Late Bronze Age hoard of Nadap (A nadapi (Fejér megye) késő bronzkori raktárlelet). Jósa András Múzeum Évkönyve (Nyíregyháza) 48, 135-184.

MARTIN, JENS

2009 Die Bronzegefäße in Mecklenburg-Vorpommern, Brandenburg, Berlin, Sachsen-Anhalt, Thüringen und

MARZATICO, FRANCO

Sachsen. Prähistorische Bronzefunde II/16. Stuttgart.

2000 L'età del Bronzo Recente e Finale. In: Lanzinger, M.-Marzatico, F.-Pedrotti, A. (eds): Storia del Trentino I. La preistoria e la protoistoria. Bologna, 367-416.

MATTHÄUS, HARTMUT

1985 Metallgefäße und Gefäßuntersätze der Bronzezeit, der geometrischen und archaischen Periode auf Cypern mit einem Anhang der bronzezeitlichen Schwertfunde auf Cypern. Prähistorische Bronzefunde II/8. München.

Merhart, GERO VON

1940 Zu den ersten Metallhelmen Europas. Bericht der Römisch-Germanischen Kommission 30, 4-41.

1958 Geschnürte Schienen. Bericht der Römisch-Germanischen Kommission (Berlin) 37-38, 91-147.

Millotte, JacQues-PIERRE

1959 Le "trésor" de Carnac et les débuts de l'Âge du Fer sur le Plateau Central. Revue du Gévaudan des Causses et des Cévennes 5, 25-43.

Mira BONOMI, ANGELO

1979 I recenti rinvenimenti del Bronzo finale alla Malpensa nella Lombardia occidentale. Atti della XXII riunione scientifica. Il Bronzo finale in Italia, Firenze, 21-23 Ottobre 1977. Firenze, 117-146.

MODRIJAN, WALTER

1953 Der urnenfelderzeitliche Grabfund aus Wörschach in Ennstal und die steirischen Schwerter der Periode Hallstatt A. Schild von Steier. Beiträge zur Steirischen Vor- und Frühgeschichte und Münzkunde (Graz) $2,24-48$.

Molloy, BARRY

2011 Use-wear analysis and use-patterns of Bronze Age swords. In: Uckelmann, M.-Mödlinger, M. (eds): Bronze Age Warfare: Manufacture and Use of Weaponry. British Archaeological Reports - International Series 2255. Oxford, 67-84.

Mountjoy, Penelope A.

1984 The Bronze Greaves from Athens. A case for a LHIIIC Date. Opuscula Atheniensia 15/11, 135-146. Mozsolics, AmÁliA

1949 Két dunántúli bronzlelet a Hallstattkorból (Deux trouvailles de bronze Hallstattiennes, retrouvées en Transdanubie). Archaeologiai Értesítő (Budapest) 76, 26-29.

1950 Der Goldfund von Velem-Szentvid. Ein Beitrag zur Metallkunst der älteren Hallstattzeit. Basel.

1955 Neuere hallstattzeitliche Helmfunde aus Ungarn (Шлемы гальштатской эпохи в Венгрии). Асta Archaeologica Academiae Scientiarum Hungaricae (Budapest) 35-54.

1967 Spätbronzezeitliche Depotfunde aus Ungarn. Inventaria Archeologica, Ungarn 2. Bonn.

1972 Beziehungen zwischen Italien und Ungarn während Bronzo recente und Bronzo finale. Rivista di Scienze Preistoriche (Firenze) 17/2, 373-399.

1985 Bronzefunde aus Ungarn. Depotfundhorizonte von Aranyos, Kurd und Gyermely. Budapest.

2000 Bronzefunde aus Ungarn. Depotfundhorizonte Hajdúböszörmény, Románd und Bükkszentlászló. (Zusammengetragen und bearbeitet von Emily Schalk.) Prähistorische Archäologie in Südosteuropa 17. Kiel.

MÖDLINGER, MARIANNE

2008 Micro-X-ray Computer Tomography in Archaeology: Analyses of a Bronze Age Sword. Insight - NonDestructive Testing and Condition Monitoring 50/5, 323-326.

2011 Herstellung und Verwendung bronzezeitlicher Schwerter Mitteleuropas. Eine vertiefende Studie zur mittelbronze- und urnenfelderzeitlichen Bewaffnung und Sozialstruktur. Universitätsforschungen zur Prähistorischen Archäologie 193. Bonn.

2013 From Greek Boar's-Tusk Helmets to the First European Metal Helmets: New Approaches on Development and Chronology. Oxford Journal of Archaeology 32/4, 391-412. 
Mödlinger, Marianne-Kasztovszky, Zsolt-Kis, Zoltán-Maróti, Boglárka, Maróti-Kovács, Imre-SzŐKEFalviNAGY, ZoltÁN-KÁLI, GYÖrgY-HorvÁth, EsZTer-SÁNTA, ZsOMbOR-El Morr, ZiAD

2014 Non-invasive PGAA, PIXE and ToF-ND analyses on Hungarian Bronze defensive armour. Journal of Radioanalytical and Nuclear Chemistry 300/2, 787-799.

Mödlinger, Marianne-Piccardo, Paolo-Kasztovszky, Zsolt-Kovács, Imre-SzöKefalvi-Nagy, Zoltán-Káli, GYÖRGY-SZILÁGYI, VERONIKA

2013 Archaeometallurgical characterization of the earliest European metal helmets. Materials Characterizations (New York) 79, 22-36.

MÖRTZ, TOBIAS

2011 At the Head of Concealment. The Deposition of Bronze Age Helmets in the Carpathian Basin. In: Berecki, S.-Németh, R. E.-Rezi, B. (eds): Bronze Age Rites and Rituals in the Carpathian Basin. Proceedings of the International Colloquium from Târgu Mureş, 8-10. October 2010. Târgu Mureş, 357-376.

2012 From Zero to Hero. Ein Beitrag zur Rekonstruktion spätbronzezeitlicher Waffengarnituren. In: Heske, I.Horejs, B. (Hrsg.): Bronzezeitliche Identitäten und Objekte. Beiträge aus den Sitzungen der AG Bronzezeit auf der 80. Tagung des West- und Süddeutschen Verbandes für Altertumsforschung in Nürnberg 2010 und dem 7. Deutschen Archäologiekongress in Bremen 2011. Universitätsforschungen zur Prähistorischen Archäologie 221. Bonn, 161-190.

2013 Zerteiltes Leid. Anmerkungen zur Deutung mutwilliger Beschädigungen von Metalldeponierungen der späten Bronzezeit. Mitteilungen der Berliner Gesellschaft für Anthropologie, Ethnologie und Urgeschichte 34, 55-66.

MÜLLER RÓBERT

2006 Várvölgy-Nagy-Lázhegy késő bronzkori földvár kutatása (Die Erforschung des spätbronzezeitlichen Burgwalles von Várvölgy-Nagy-Lázhegy). In: Kovács, Gy.-Miklós, Zs. (szerk.): „Gondolják, látják az várnak nagy voltát..." Tanulmányok a 80 éves Nováki Gyula tiszteletére. Budapest, 227-236.

MÜLlER-KARPE, HERMANN

1959a Beiträge zur Chronologie der Urnenfelderzeit nördlich und südlich der Alpen. Tafeln. RömischGermanische Forschungen 22. Berlin.

1959b Beiträge zur Chronologie der Urnenfelderzeit nördlich und südlich der Alpen. Tafeln. RömischGermanische Forschungen 22. Berlin.

1962 Zur spätbronzezeitlichen Bewaffnung in Mitteleuropa und Griechenland. Germania (Berlin) 40, 255287.

NAUE, JULIUS

1896 Armi Italiane della Collezione Naue in Monaco. Bulletino di Paletnologia Italiana (Roma) 22, 94-104.

1903 Die vorrömischen Schwerter aus Kupfer, Bronze und Eisen. München.

NEBELSICK, LOUIS

1997 Auf Biegen und Brechen. Ekstatische Elemente bronzezeitlicher Materialopfer - Ein Deutungsversuch. In: Hänsel, A.-Hänsel, B. (Hrsg.): Gaben an die Götter. Schätze der Bronzezeit Europas. Bestandkataloge Bd. 4. Berlin, 35-41.

2000 Rent asunder: ritual violence in Late Bronze Age hoards. In: Pare, Ch. F. E. (ed.): Metals Make the World Go Round. The Supply and Circulation of Metals in Bronze Age Europe. Proceedings of a conference held at the University of Birmingham in June 1997. Oxford, 160-175.

NÉMETI, JÁNOS

1972 Coiful de bronz de la Pişcolt (Bronzehelm von Pişcolt). Studii şi Comunicări (Satu Mare) 2, 113-119. NESSEL, BIANKA

2009 Bronzenes Spezialgerät. Ein Metallhandwerkerdepot im Berliner Museum für Vor- und Frühgeschichte. Acta Praehistorica et Archaeologica (Berlin) 41, 37-65.

2010 Schmiede und Toreuten in den urnenfelderzeitlichen Depotfunden des Karpatenbeckens? Funktionanalyse von Handwerksgerät und soziale Implikationen. In: Horejs, B.-Kienlin, T. L. (Hrsg.): Siedlung und Handwerk. Studien zu sozialen Kontexten in der Bronzezeit. Beiträge zu den Sitzungen der Arbeitsgemeinschaft Bronzezeit 2007 und 2008. Universitätsforschungen zur Prähistorischen Archäologie (Bonn) 194, 373-386.

NESTOR, ION

1935 Ein Bronze-Depot aus Moigrad, Rumänien. Praehistorische Zeitschrift (Berlin) 26/1/2, 24-57.

Neugebauer, Johannes-Wolfgang-Blel, Christoph-Lochner, Michaela-Neugebauer-Maresch, ChristineGATTRINGER, Alois-PreinfalK, FritZ

1998-1999 Zu Metall- und Keramikdepots der Bronzezeit aus dem Zentralraum Niederösterreich. In: KrennLeeb, A.-Neugebauer, J.-W. (Hrsg.): Depotfunde der Bronzezeit im mittleren Donauraum. Archäologie Österreichs Sonderausgabe (Wien) 9/10, 5-45. 
NOVÁK MARIANN-VÁCZi GÁBOR

2012 Késő bronzkori fegyverlelet a Bakonyból - Megjegyzések az urnamezős múvelődés fegyverdeponálási szokásaihoz (A Late Bronze Age weapon find from the Bakony region, Hungary - Notes on the weapon deposition practices of the Urnfield culture). Ösrégészeti Levelek/Prehistoric Newsletter (Budapest) 12, 94-114.

NOVÁK, PETR

1975 Die Schwerter in der Tschechoslowakei I. Prähistorische Bronzefunde IV/4. München.

NOVOTNÁ, MÁRIA

1970 Die Bronzehortfunde in der Slowakei. Spätbronzezeit. Bratislava.

OSGOOD, RICHARD

1998 Warfare in the Late Bronze Age of North Europe. British Archaeological Reports - International Series

OTTO, KARL-HEINZ 694. Oxford.

1955 Ein Bronzetassen-Geschirrfund von Braunsbedra, Kr. Merseburg. Jahresschrift für Mitteldeutsche Vorgeschichte 39, 163-175.

Papadopoulos, Thanasis J.

1984 Two Mycenaean Weapons in the National Museum, Athens In: Papadopoulos, Thanasis J.-KontorliPapadopoulos, L. (eds): Notes from Achaea. The Annual of the British School at Athens 79, 221-224.

PARE, CHRISTOPHER F. E.

2004 Die Wagen der Bronzezeit in Mitteleuropa. In: Burmeister, S.-Endlich, C.-Kloos, E. (Hrsg.): Rad und Wagen. Der Ursprung einer Innovation. Wagen im Vorderen Orient und Europa. Oldenburg, 355-372.

PATAY, PÁL

1969 Der Bronzefund von Mezőkövesd. Acta Archaeologica Academiae Scientiarum Hungaricae 21, $167-261$.

1990 Die Bronzegefäße in Ungarn. Prähistorische Bronzefunde II/10. München.

1996 Einige Worte über Bronzegefäße der Bronzezeit. In: Kovács, T. (Hrsg.): Studien zur Metallindustrie im PATEK, ERZSÉBET

Karpatenbecken und den benachbarten Regionen. Budapest, 405-420.

1968 Die Urnenfelderkultur in Transdanubien. Budapest.

PAULÍK, JOZEF

1963 K problematike čakanskej kultúry v Karpatskje Kotline (Zur Problematik der Čaka-Kultur im Karpatenbecken). Slovenská Archeológia (Nitra) 11, 269-338.

1968 Panzer der jüngeren Bronzezeit aus der Slowakei. Berichte der Römisch-Germanischen Kommission (Berlin) 49, 41-61.

Peroni, Vera BiAnco

1961 Bronzi dal Territorio del Fucino. Rivista di Scienze Preistoriche (Firenze) 16, 127-206.

1970 Die Schwerter in Italien (Le spade nell'Italia continentale). Prähistorische Bronzefunde IV/1. München.

1976 Die Messer in Italien (I coltelli nell'Italia continentale). Prähistorische Bronzefunde VII/2. München.

PETERSEN, ERNST

1913 Die geschweiften Bronzemesser in Schlesien. Altschlesien (Breslau) 3, 205-227.

PETRES, ÉVA

1982 Neue Angaben über die Verbreitung der spätbronzezeitlichen Schutzwaffen. Savaria (Szombathely) 16, 57-80.

1990 Anhang: Die Bronzegefäße aus dem Depotfund von Nadap. In: Patay, P.: Die Bronzegefäße in Ungarn. Prähistorische Bronzefunde II/10. München, 87-93.

Petres, Éva-JANKOVITS, KaTALIN

2014 Der spätbronzezeitliche zweiteilige Bronzebrustpanzer aus der Donau in Ungarn. Acta Archaeologica Academiae Scientiarum Hungaricae (Budapest) 65, 43-71.

Petrescu-Dîmbovița, Mircea

1978 DieSicheln in Rumänien mit Corpus der jung- und spätbronzezeitlichen Horte Rumäniens. Prähistorische Bronzefunde XVIII/1. München.

Pietzsch, ARtur

1968 Rekonstruktionen getriebener Bronzegefäße. Arbeits- und Forschungsberichte zur sächsischen Bodendenkmalpflege (Dresden) 18, 237-283.

PRENDI, FRANO

1975 Un Aperçu sur la Civilisation de la Premiere Periode du fer en Albanie. Iliria (Tirana) 3, 109-138.

PRÜSSING, GERLINDE

1991 Die Bronzegefäße in Österreich. Prähistorische Bronzefunde II/5. Suttgart.

REINECKE, PAUL

1930 Spätkeltische Oppida im rechtsrheinischen Bayern. Bayerische Vorgeschichtsblätter (München) 9, 29-52. 
REZI, BOTOND

2011 Voluntary destruction and fragmentation in Late Bronze Age Hoards from Central Transylvania. In: Berecki, S.-Németh, E. R.-Rezi, B. (eds): Bronze Age Rites and Rituals in the Carpathian Basin. Târgu Mureş, 303-334.

RICHLÝ, HEINRICH

1894 Die Bronzezeit in Böhmen. Wien.

ŘíHOVSKỲ, JIŘí

1972 Die Messer in Mähren und dem Ostalpengebiet. Prähistorische Bronzefunde VII/1. München.

ROMSAUER, PETER

1977 Výsledky záchranného výskumu v Hornej Seči. Archeologické Výskumy a Nálezy na Slovensku v Roku 1976. Nitra, 241-242.

ROSKA, MÁRTON

1932 Der Bronzefund von Borév. Mannus. Zeitschrift für Vorgeschichte (Würzburg) 24, 540-547.

SALAŠ, MiLAN

2002 Neue urnenfelderzeitliche Bronzedepotfunde in Mähren (Überlegungen zum Depotfundhorizont Přestavlky). In: Dufková, M. (ed.): In Honour of Mária Novotná. Anodos (Trnava) 2, 261-275.

2005 Bronzové depoty střední až pozdní doby bronzové na Moravě na a ve Slezsku I (Hügelgräberbronzeund urnenfelderzeitliche Metalldepots in Mähren I). Text. Brno.

SALZANI, LUCIANO

1985 Desmontà (Comune di Veronella). Quaderni di Archeologia del Veneto 1, 42-43. SCHAUER, PETER

1971 Die Schwerter in Süddeutschland, Österreich und der Schweiz I (Griffplatten-, Griffangel- und Griffzungenschwerter). Prähistorische Bronzefunde IV/2. München.

1982 Die Beinschienen der späten Bronze- und frühen Eisenzeit. Jahrbuch des Römisch-Germanischen Zentralmuseums Mainz 29, 100-155.

SCHLIZ, ALFRED

1909 Urgeschichte Württembergs: Eine kurzgefasste Darstellung. Stuttgart.

SCHÜtZ, CORNELIA-BARTEL, ANTJA-KunTER, MANFrED

2006 Das urnenfelderzeitliche Gräberfeld von Zuchering-Ost, Stadt Ingolstadt. Kallmünz.

SIEDLACZEK, MiCHAEL

2011 Der experimentelle Nachguss von bronzezeitlichen Schwertern. Experimentelle Archäologie in Europa

ŠINKOVEC, IRENA

(Oldenburg) 10, 109-119.

1995 Katalog posameznih kovinskih najdb bakrene in bronaste dobe (Catalogue of Individual Metal Finds from the Eneolithic and Bronze Ages). In: Teržan, B. (ed.): Depojske in posamezne kovinske najdbe bakrene in bronaste dobe na Slovenskem (Hoards and Individual Metal Finds from the Eneolithic and Bronze Age in Slovenia I). Ljubljana, 29-126.

SNODGRASS, A. McELREA

1967 Arms and Armour of the Greeks. New York

SOROCEANU, TUDOR

2008 Die vorskythenzeitlichen Metallgefäße im Gebiet des heutigen Rumänien (Vasele de metal prescitice de pe actualul teritoriu al României). Berlin.

2011 "GLADIUS BARBARICO RITU HUMI FIGITUR NUDUS”. Schriftliches, Bildliches und Ethnologisches zur Bedeutung der Schwerter und der Schwertdeponierungen außerhalb des militärischen Verwendungsbereiches. Tyragetia Arheologie Istorie Antiča (Chişinău) V/1, 39-116.

SOROCEANU, TUDOR-LAKÓ, ÉVA

1981 Depozitul de bronzuri de la Sîg (Jud. Sălaj). Acta Musei Porolissensis (Zalău) 5, 145-168.

SÓREGI JÁNOS

1936 Jelentés a Déri Múzeum 1933. évi múködéséről és állapotáról. Debreceni Déri Múzeum Évkönyve 24, 5-38.

SPERBER, LOTHAR

1992 Bemerkungen zur sozialen Bewertung von goldenem Trachtschmuck und Schwert in der Urnenfelderkultur. Arhäologisches Korrespondenzblatt (Mainz) 22, 1991, 63-77.

SPRATER, FRIEDRICH

1928 Die Urgeschichte der Pfalz, zugleich Führer durch die vorgeschichtliche Abteilung des Historischen Museums der Pfalz. Veröffentlichungen der Pfälzischen Gesellschaft zur Förderung der Wissenschaften. Speyer.

SPROCKHOFF, ERNST

1926 "Helm”. Reallexikon der Vorgeschichte (Berlin) 5, 290-298.

1930 Zur Handelsgeschichte der germanischen Bronzezeit. Vorgeschichtliche Forschungen 7. Berlin.

1931 Die germanischen Griffzungenschwerter. Berlin-Leipzig. 


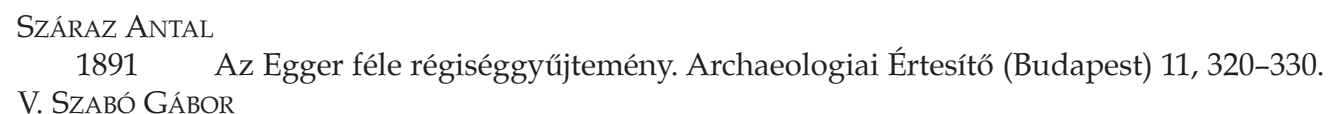
V. SZABÓ GÁBOR

2009 Fémkereső múszeres kutatások kelet-magyarországi késő bronzkori és kora vaskori lelőhelyeken. Beszámoló az ELTE Régészettudományi Intézete által indított bronzkincskutató program 2009. évi eredményeiről (Metal detection investigations at Eastern Hungarian Late Bronze Age and Early Iron Age sites. Report on the results of the bronze hoard exploration project of the Institute of Archaeology of ELTE in 2009). Kisfaludi J. (szerk.): Régészeti kutatások Magyarországon (Archacological Investigatio s in Hungary). Budapest, 19-38.

2013 Late Bronze Age Stolen. New Data on the Illegal Acquisition and Trade of Bronze Artefacts in the Carpathian Basin. In: Anders, A.-Kalla, G.-Kiss, V.-Kulcsár, G.-V. Szabó, G. (eds): Moments in Time. Papers Presented to Pál Raczky on His 60 th Birthday. Ösrégészeti Tanulmányok/Prehistoric Studies 1. Budapest, 793-815.

SZABÓ IsTVÁN

1885 A pinczehelyi régiségekről. Archaeologiai Értesítő (Budapest) 5, 337-338.

SZABÓ GÉZA

1994 A Kárpát-medencei késő bronzkori sisakok készítésének problémái egy újabb lelet alapján (Probleme der Herstellung der spätbronzezeitlichen Helme im Karpatenbecken im Lichte eines neuen Fundes). In: Lőrinczy, G. (szerk.): A kőkortól a középkorig. Tanulmányok Trogmayer Ottó 60. születésnapjára (Von der Steinzeit bis zum Mittelalter. Studien zum 60. Geburtstag von Otto Trogmayer). Szeged, 219-227.

SZÉCHENYI BÉLA

1887 A pölöskei bronzleletről. Archaeologiai Értesítő (Budapest) 7, 57-58.

SZEVERÉNYI VAJK

2013 Bronzkori „háztúznéző”: szándékos házégetés és anyagi metaforák a Kárpát-medence kora és középső bronzkorában (Deliberate house-burning and material metaphors in the Early and Middle Bronze Age of the Carpathian Basin). Ösrégészeti Levelek/Preshistoric Newsletter. MOMOS VII. Őskoros Kutatók VII. Összejövetele, 2011. március 16-18. Százhalombatta, Matrica Múzeum, 215-232.

SZOMBATHY, JOSEF

1913 Altertumsfunde aus Höhlen bei St. Kanzian im österreichischen Küstenlande. Mitteilungen der Prähistorischen Kommission der kais. Akademie der Wissenschaften zu Wien 2/2, 127-190.

Thrane, Henrik

1965 Dänische Funde fremder Bronzegefäße der jüngeren Bronzezeit (Periode IV). Acta Archaeologica København 36, 157-207.

1975 Europæiske forbindelser. København.

TOČIK, ANTON-PAULík, JOZEF

1960 Výskum mohyly v Čake v rokoch 1950-1951 (Die Ausgrabung eines Grabhügels in Čaka in den Jahren

TREHERNE, PAUL 1950-51). Slovenská Archeológia (Nitra) 8/1, 59-124.

1995 The warrior's beauty: The masculine body and self-identity in Bronze-Age Europe. Journal of European Archaeology (Ashgate) 3/1, 105-144.

TROGMAYER, OTTO

1963 Beiträge zur Spätbronzezeit des südlichen Teils der Ungarischen Tiefebene. Acta Archaeologica Academiae Scientiarum Hungaricae (Budapest) 15, 85-112.

UnDSET, INGVALD MARTIN-MESTORF, JOHANNA

1882 Das erste Auftreten des Eisens in Nord-Europa: Eine Studie in der vergleichenden historischen

VÁCZI GÁBOR Archäologie. Hamburg.

2014 A hálózatelemzés régészeti alkalmazásának lehetőségei a késő bronzkori fémmúvesség tükrében (Potentials of the archaeological application of network analysis in the light of Late Bronze Age metal-

VELIAČIK, LADISLAV lurgy). Archaeologiai Értesítő (Budapest) 139, 261-291.

2012 Nože z doby bronzovej na Slovensku (Bronzezeitliche Messer aus der Slowakei). Slovenská Archeológia (Nitra) 60/2, 285-342.

VELIAČIK, LADISLAV-ROMASAUER, PETER

1994 Vývoj a vztah osidlenia lužickyh a stredodunajskych popolnicovych poli na západnom Slovensku. Archaeologica Slovaca Monographiae Catalogi 6. Nitra.

VERDELIS, NichOLAS M.

1967 Neue Funde von Dendra. Mitteilungen des Deutschen Archäologischen Instituts, Abteilung Athen 82, $1-53$.

VINSKI-GASPARINI, KSENIJA

1973 Kultura polja sa žarama u sjevernoj Hrvatskoj (Die Urnenfelderkultur in Nordkroatien). Zadar. 
VOSTEEN, MARKUS UwE

1999 Urgeschichtliche Wagen in Mitteleuropa. Eine archäologische und religionswissenschaftliche Untersuchung neolithischer bis hallstattzeitlicher Befunde. Freiburger Archäologische Studien 3. Rahden/ Westf.

WAGNER, KARL HEINZ

1943 Nordtiroler Urnenfelder. Römisch-Germanishe Forschungen 15. Berlin.

WARNER, RICHARD

2004 A unique 'urnfield find from Ireland. A Late Bronze Age hoard including two bronze bowls imported from Central Europe has recently been discovered near a complex of contemporary ceremonial sites in County Armagh. PAST - The Newsletter of the Prehistoric Society 48, November 2004.

Weber, Claus

1996 Die Rasiermesser in Südosteuropa. Prähistorische Bronzefunde VIII/5. Stuttgart.

WindHOLZ-KONRAD, MARIA

2008 Der prähistorische Depotfund vom Brandgraben im Kainschtal, Steiermark. Fundberichte aus Österreich Materialhefte (Wien) 6, 48-53.

WOSINSZKY MóR

1890 Bonyhádvidéki bronzlelet. Archaeologiai Értesítő (Budapest) 10, 29-42.

1896 Tolnavármegye az őskortól a honfoglalásig 1. Budapest.

WÜSTEMANN, HARRY-RIEDERER, JOSEF

2004 Die Schwerter in Ostdeutschland. Prähistorische Bronzefunde IV/15. Stuttgart. YOSHIMURA, KENICHI

2006 A japánok és a kard. Budapest.

ZIPF, GABRIELE

2003 Studien zu den Anfängen figürlicher Darstellungen im endbronze- und früheisenzeitlichen Frankreich und Italien. Motive, Dekoträger und Kontexte. Dissertation zur Erlangung des Doktorgrades am Fachbereich für Geschichts- und Kulturwissenschaften der Freien Universität Berlin. Berlin.

ZOLTAI LAJOS

1909 Bronzedények Hajdúsámsonból és Csíkszentkirályról. Múzeumi és Könyvtári Értesítő 3, 131-136.

ŽILINCOVÁ, LuCIA

2010 Pohebriská lužickej kultúry v Jasenici a Sedmerovci (Gräberfelder der Lausitzer Kultur in Jasenica und Sedmerovec). Študijné Zvesti Archeologického Ústavu Slovenskej Akadémie Vied (Nitra) 48, 141-214.

\title{
ÚJ KÉSŐ BRONZKORI, KELET-KÖZÉP-EURÓPAI HARCOSFELSZERELÉS
}

\author{
TARBAY JÁNOS GÁBOR
}

A HM Hadtörténeti Intézet és Múzeumba vélhetóleg az 1990-es években került be egy tizennyolc tárgyból álló késő bronzkori (Ha A-Ha B1) „leletegyüttest” (14-18. kép). A leletegyüttest alkotó kiemelkedő, eddig közöletlen tárgyak a következők: egy nyélnyújtványos kard a hüvely szerelékével, egy kónikus sisak, egy lábszárvédőpár, három nyélnyújtványos kés, egy Fuchsstadt-típusú csésze és egy vélhetően kocsialkatrészként értékelhetó tárgy. A kérdéses darabok elókerülési helye és ideje ismeretlen. Összetartozásukat ma már csak tipológiai és technológiai jellemzőik alapján tarthatjuk megalapozottnak.

A hosszított markolatú, nyélnyújtványos kard legközelebbi formai párhuzamait - meglepő módon - nem a Kárpát-medencében, hanem Észak-Itália (Casale sul Sile, Lago Trasimeno), az Égeikum (Clauss, Graditsa, Kallithea, Mouliana) és a Balkán (Krklino, Sisak) területén találjuk meg (I. lista; 1. kép). Mivel legközelebbi formai párhuzamainak keltezése bizonytalan, a fegyver időrendi értékelése során kiindulási pontként egyedül a görögországi „harcossírokra" (pl. Mouliana és Kallithea) támaszkodhatunk (LH IIIC - Ha A1). A darab érdekességét növeli, hogy egy Kárpát-medencei viszonylatban is ritka, fém kardhüvely-szerelék is tartozott hozzá (4. kép 2, 14. kép 2).
A védőfegyverek közül a kónikus sisak jól körülírható formai párhuzamokkal rendelkezik, elsősorban a Br D és Ha A1 időszak Kárpát-medencei kincsegyüttesein belül (II. lista; 5. kép). A „leletegyüttes” legkiemelkedőbb darabja az a lábszárvédó-pár, amelynek párhuzamait a Kárpát-medence (Bodrogkeresztúr, Bonyhád vidéke, Brodski Varoš, Esztergom-Szentgyörgymező, Nadap, Poljanci 1), Ausztria (Brandgraben), Franciaország (Cannés-Écluse 2) és Itália területén (Desmontá, Malpensa, Pergine) találjuk meg. Jelentősége, hogy mintái és azok készítésének technikája - néhány finomabb eltéréstől eltekintve - pontosan megfeleltethető a Perginéről (Olaszország, Trentino) előkerült votív lábszárvédődepó darabjaival (III. lista; 7. kép). E tárgy párhuzamleleteinek nagy része egyértelmúen a $\mathrm{Ha}$ A1 szakaszhoz köthető. Ennek ellenére a perginei darabokat a kutatás stilisztikai alapon fiatalabb tárgyakként (Ha B1) határozta meg, jórészt a proto-villanova kerámialeletek (Bismantova, Monteleone di Spoleto, Pianello) és a Tolfa-Coste del Marano-i kincs fibuláinak ábrázolásaira alapozva. A „leletegyüttes” három kése közül kettő tipológiailag nehezen volt körülírható egyedi formája (6.) vagy olvadt állapota miatt (8.). A 6. darab viszont összefüggésbe hoz- 
ható az úgynevezett Pustiměř-típusú késekkel, amelyek leginkább a Kárpát-medence területén jellemzőek (IV. lista; 10. kép). Jól keltezhető volt a Fuchsstadt-típusú csésze is, amely a "Ha A2” és Ha B1 között Nyugat- és Közép-Európa területén terjedt el leginkább (V. lista; 12. kép). Az „együtteshez" tartozott még egy csőszerú tárgy, amelynek pontos párhuzamai nem ismertek, viszont formailag leginkább a kocsiszerelék köréhez kapcsolható (18. kép 18). A fentieken kívül számos kisebb, klasszifikálhatatlan lemeztöredék is előkerült, amelyeket vastagságadataik alapján nem lehetett összefüggésbe hozni a korábban ismertetett lemeztárgyak egyikével sem (17. kép 10.1-17).

Elemzésünk másik célja a tárgyak készítéstechnológiai és tárgymanipulációs nyomainak leírása és értelmezése volt. Ennek kapcsán fontos említenünk, hogy megfigyeléseinket restaurálatlan állapotú tárgyakon végeztük, így kiválóan meg tudtuk határozni a recens, deponálást követő sérüléseket (pl. 2. kép 6-7, 11. kép 2). Ezek a világosan elkülöníthető törésfelületek sajnálatos módon gyakorlatilag mindegyik tárgyon észlelhetók voltak. A 7. késen figyelhető meg az egyetlen olyan törés, amelynél felvethető volt a bronzkori eredet (18. kép 7). Ez a tény alátámaszthatja azt a feltételezést, miszerint a "leletegyüttes" teljesebb és épebb állapotban kerülhetett a földbe. A legérdekesebb eredményt a nyélnyújtványos kard szolgáltatta. Annak ellenére, hogy ezen a tárgyon több olyan nyomot is meg lehetett figyelni, amelyek a használattal hozhatók összefüggésbe (élezés, csorbulás, markolatszegecsek vájatosodása), mind a makroszkopikus megfigyelések, mind pedig a röntgenfelvételek egy másik értelmezési lehetóséget támasztottak alá (2. kép 1-2,5). A kard pengéjének belső szerkezetében megfigyelhetó intenzív porozitás teljesen alkalmatlanná tehette a kérdéses fegyvert valós harci használatra, mivel pengéje könnyen eltörhetett (ahogyan ez az egyik recens törésénél is megfigyelhetó volt) (2. kép 6-7, 3. kép). Rendkívül fontos megfigyelés a hőhatás okozta sérülések elkülönítése, amelyek véleményem szerint alátámaszthatják az elemzett tárgyak egy együttesként való értékelését. Fontos megjegyezni, hogy ezek hősérülések, de a tárgyakon látható egyéb rongálások is "megtervezett módon” az egyes darabok használhatatlanná tételét célozták (2. kép 3-4, 6. kép, 9. kép 3, 11. kép 1, 3, 6). Hasonló, hőhatáshoz köthető rongálásokkal elsősorban hamvasztásos rítusú temetkezésekben (pl. Farkasgyepú-Pöröserdő 2), ritkábban depóleletekben is (pl. Pila del Brancon) találkozhatunk.

A tanulmányban bemutatott vizsgálatok eredményei alapján a HM Hadtörténeti Intézet és Múzeum gyújteményében látható „leletet” nagy valószínúséggel összetartozónak ítélhetjük. A tárgyak készítéstechnikája, ritkasága, nagyrégiós kapcsolatrendszere és nem utolsósorban a "lelet" összetétele a Kárpát-medencei és dél-európai térségben megfigyelhető, Ha A-tól megjelenő „harcossírok” (pl. Kallithea, Portes 3), elit temetkezések (pl. Čaka), illetve kiemelkedő depóegyüttesek (Nadap, Pázmándfalu, Rinyaszentkirály, Pila del Brancon, Škocjan-Mušja jama) felé mutatnak. Vélhetően a tárgyak is egy ilyen együttes részeként kerültek földbe. 